\title{
HOST COMMUNITY PERCEPTIONS OF FREEDOM CAMPING IMPACTS: A SOCIAL EXCHANGE THEORY PERSPECTIVE
}

by

Adele Lonergan

\author{
A thesis \\ submitted to the Victoria University of Wellington \\ in partial fulfilment of the requirement for the degree of \\ Masters of Tourism Management
}

Victoria University of Wellington 


\section{ABSTRACT}

Residents' perceptions of tourism impacts in a destination have been widely examined throughout tourism literature. These studies, often underpinned by social exchange theory, show that residents who are dependent on the tourism industry, or perceive a greater level of economic gain from it, tend to have more positive perceptions of the impacts than others (Andereck et al., 2005; Ap, 1992; Tosun, 2002). According to Tosun (2002, p.233), 'residents benefiting from tourism have a higher level of support for it and thus report more positive impacts'. It is suggested that destinations need to understand what the impacts of tourism are to manage them effectively (Haywood, 1988).

Whilst much research has been done on tourism impacts, little work has focused on the activity of freedom camping and how it can impact a destination. Freedom camping is when an individual camps on public land that is not a recognised camping ground or holiday park. This exploratory study uses the research location of the Taupō District, New Zealand, to examine the impacts of freedom camping on the host community of the destination. The aim of this research is to understand what the host community's perceived impacts of freedom camping are and how these perceptions may vary based on a host community member's employment relationship with tourism. Additionally, it aims to examine the host community's overall support of freedom camping.

A sample of 182 Taupō District residents were surveyed using researcher administered selfcomplete questionnaires. Validated tourism impact items were adopted and combined with freedom camping impacts to measure the host community's perceptions of freedom camping's impact in the district. Residents were self-appointed into one of four employment groups; those directly employed in tourism, those indirectly employed in tourism, those whose employment has no relation to tourism, and those not in employment.

Findings of this study show the differing perceptions within the host community towards freedom camping impacts, with the most negatively perceived impacts pertaining to the effects on the natural environment and public spaces. It was also found that there were no statistically significant differences in the perceptions between the employment groups evaluated in the study. Overall, there are varying levels of support for freedom camping in the Taupō District, with respondents highlighting the need for more facilities and regulations to manage the activity. 
This research produces important implications for academia by contributing to the knowledge base on freedom camping and recommending avenues of future research. Furthermore, this research has implications for the Taupō District Council and Government by identifying the key areas of concern of the host community about freedom camping, which need to be addressed and managed to reduce the negative impacts and ensure the activity's success.

Key words: Freedom Camping, Tourism Impacts, Host Community, Social Exchange Theory, Taupō District 


\section{DEDICATION}

To my Grandad, Thomas Ryan - the tourist who never went home. 


\section{ACKNOWLEDGEMENTS}

I would like to acknowledge all the people who were involved in the creation of this thesis. Thanks to Dr Christian Schott for his advice in this research. I would also like to say a massive thanks to Lisa Woods for advising me on the statistical testing and to the School of Management administrative team, particularly Luisa Acheson and Megan Key, for their great support and facilitating my data collection trip to Taupō. I would also like to thank all the respondents for contributing their time and thoughts. Additionally, I would like to thank all my family and friends. Louise, Martin, Colette, John, Patrick, and Maretta your support for me during this time has been greatly appreciated. Lastly, thanks to Greg for encouraging me to keep going and putting up with all my complaining. I could not have done it without all of you. 


\section{TABLE OF CONTENTS}

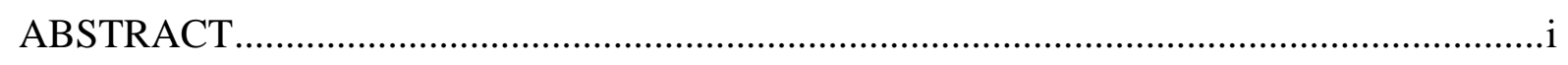

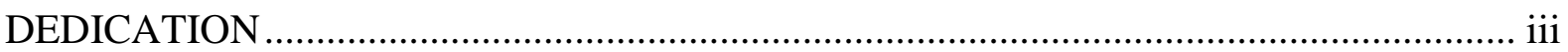

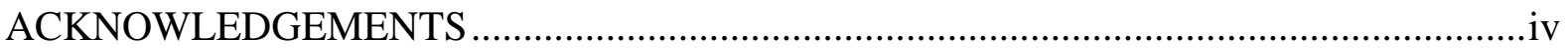

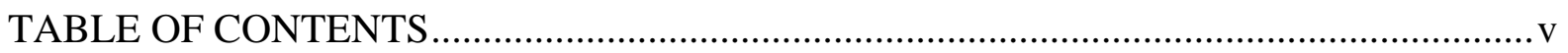

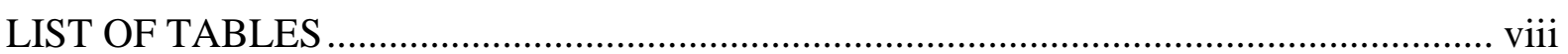

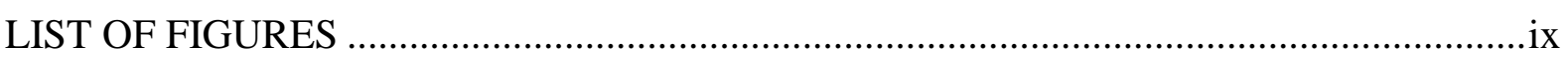

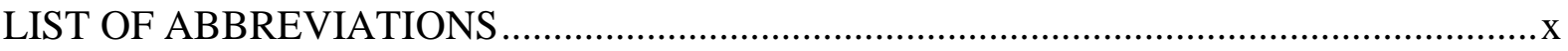

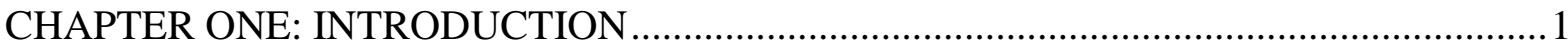

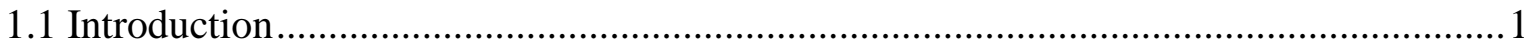

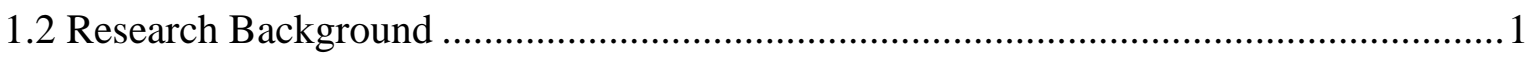

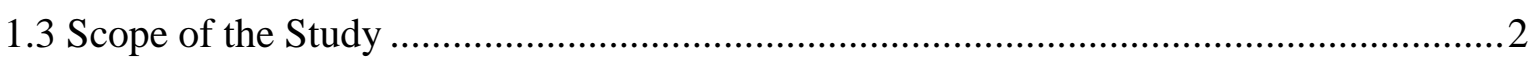

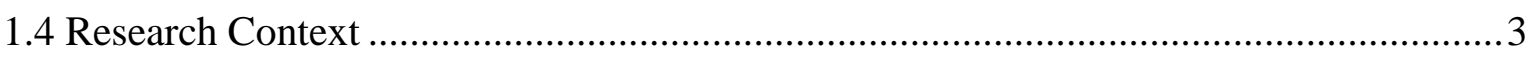

1.4.1 Tourism and Freedom Camping in New Zealand...................................................

1.4.2 Overview of the Taupō District ………………………....................................

1.4.3 Tourism and Freedom Camping in the Taupō District .............................................

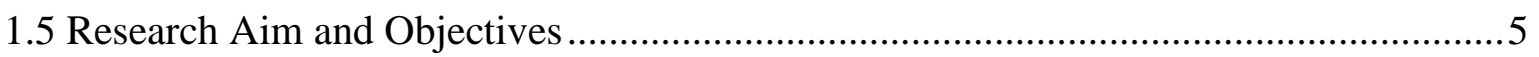

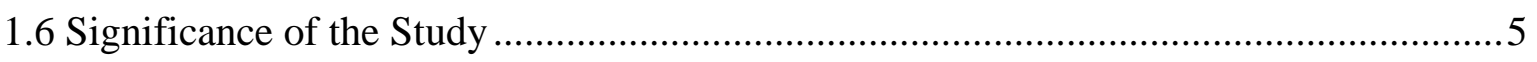

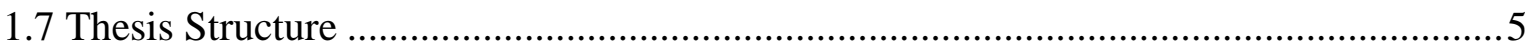

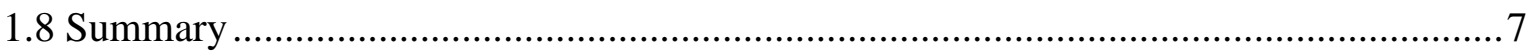

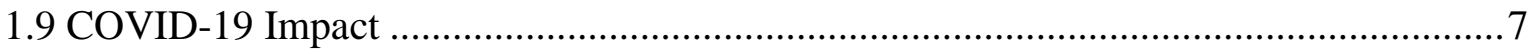

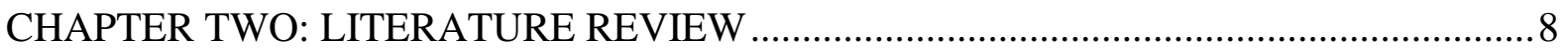

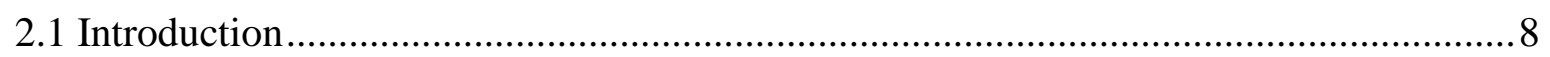

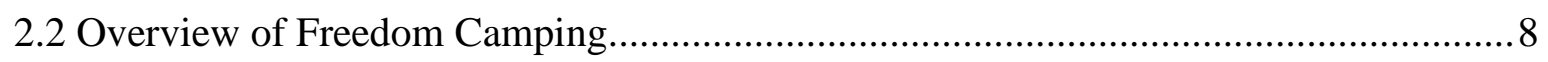

2.3 Freedom Camping in New Zealand .........................................................................

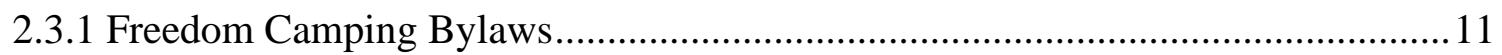

2.3.2 New Zealand Freedom Camping Statistics............................................................11

2.3.3 New Zealand Freedom Camping Funding and Resources....................................... 14

2.3.4 Freedom Camping and Public Awareness ............................................................. 15

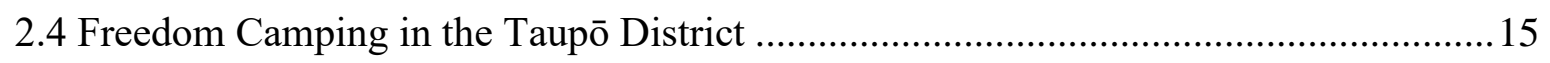

2.4.1 Taupō District Council Freedom Camping Bylaw 2017 ......................................... 16

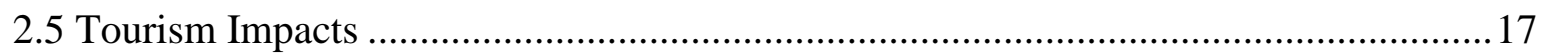


2.5.1 Social Impacts

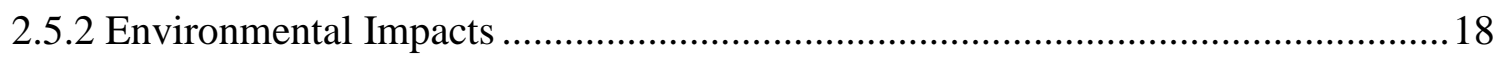

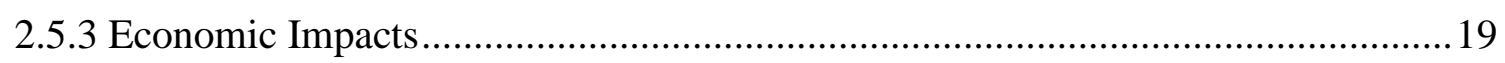

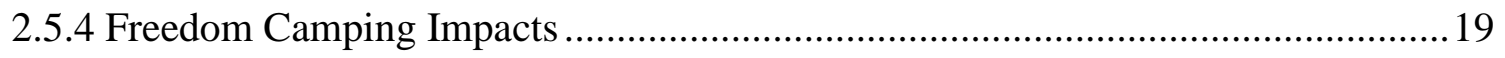

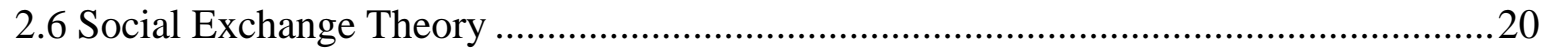

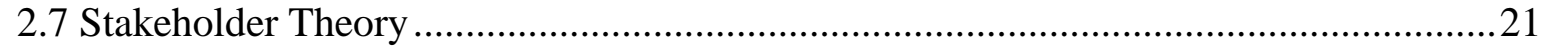

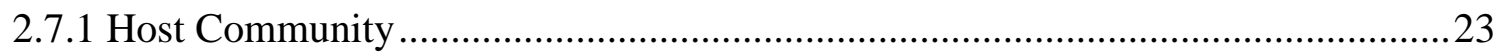

2.7.2 Host Community Perceptions and Attitudes to Tourism .....................................23

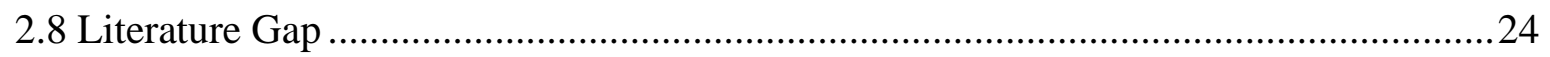

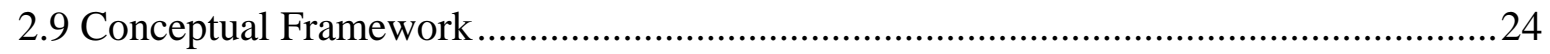

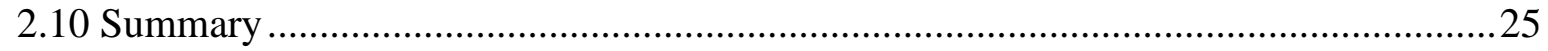

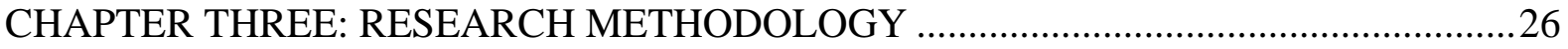

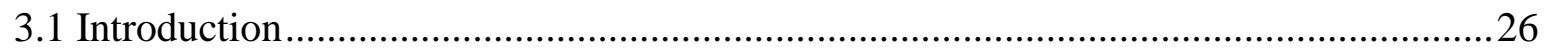

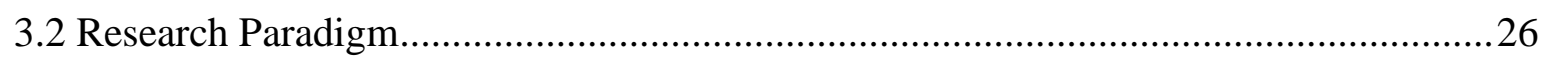

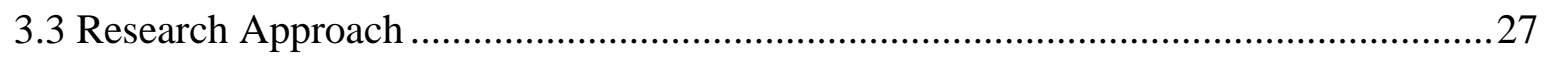

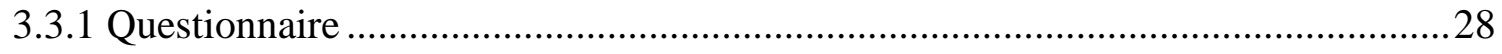

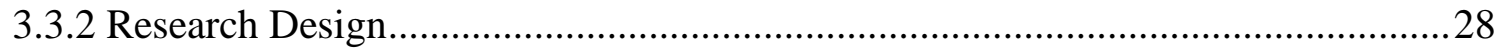

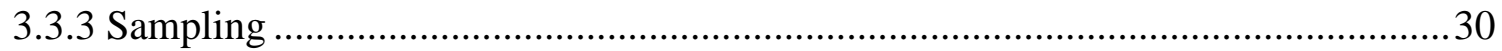

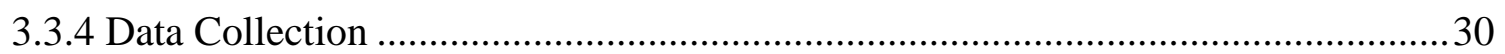

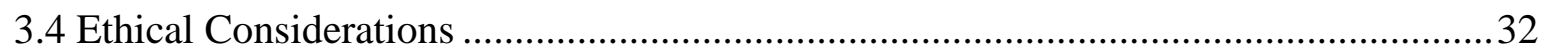

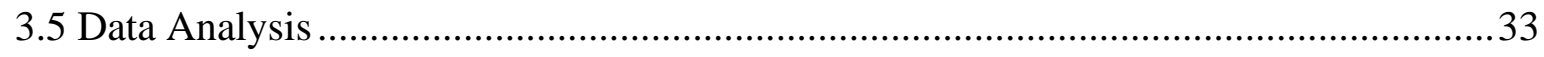

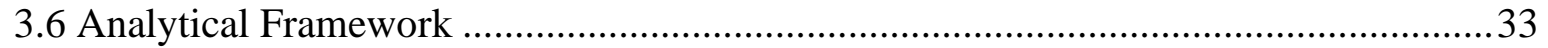

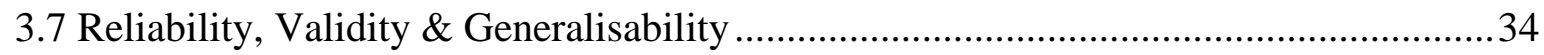

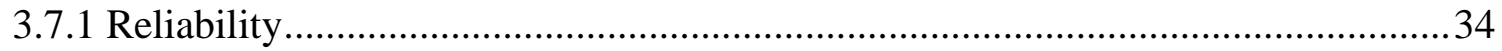

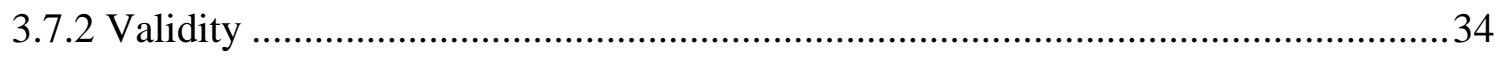

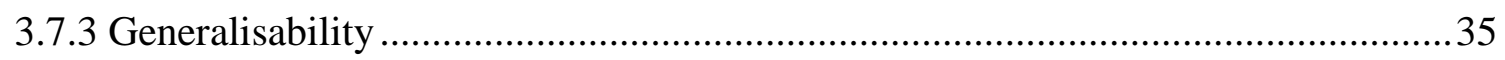

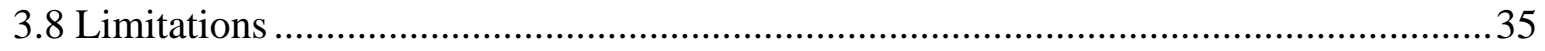

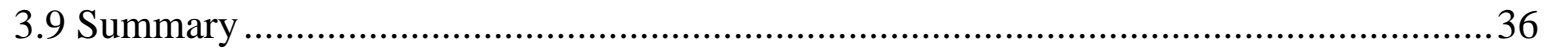

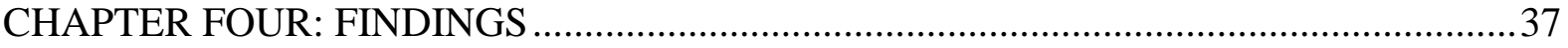

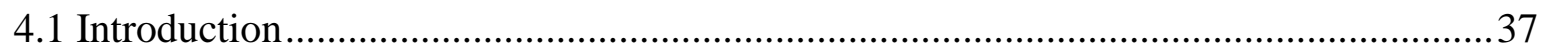

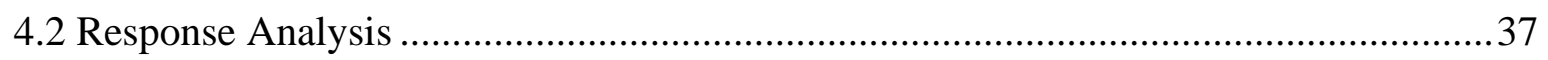

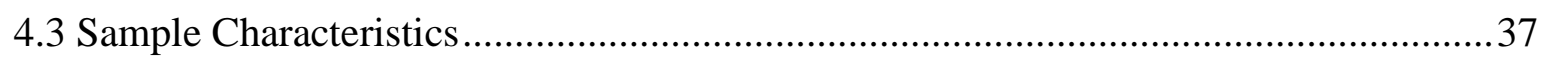

4.3.1 Sample Characteristics Overview .................................................................. 37 
4.3.2 Characteristic Analysis of Groups

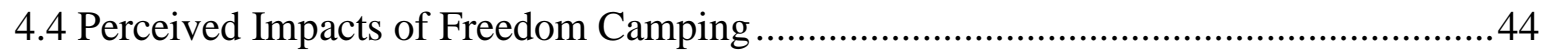

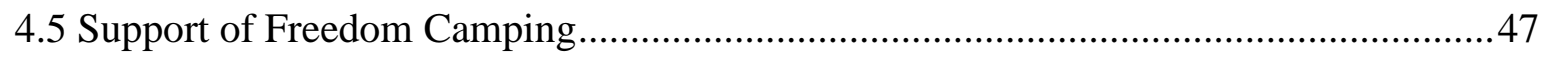

4.6 Relationship Between Perceived Impacts and Employment Group ............................52

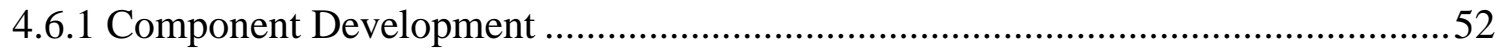

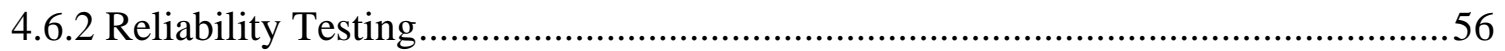

4.6.3 Component Comparison Between Groups.............................................................56

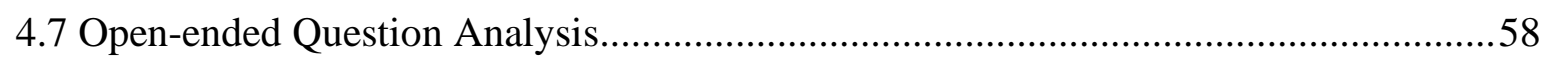

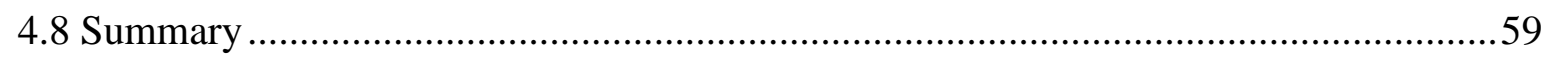

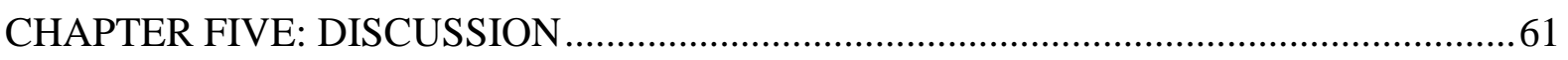

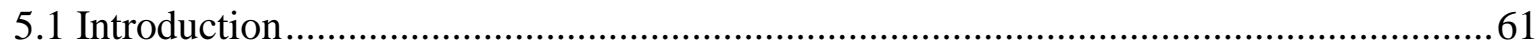

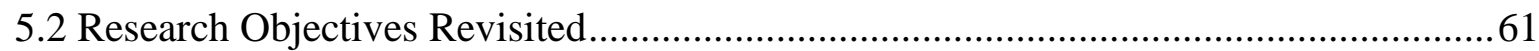

5.3 Host Community Perceptions of Freedom Camping Impacts ....................................61

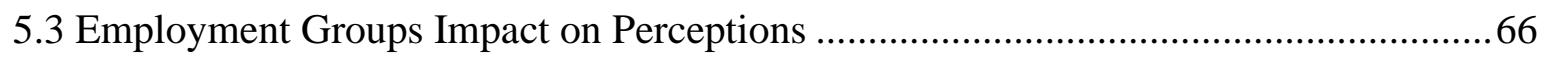

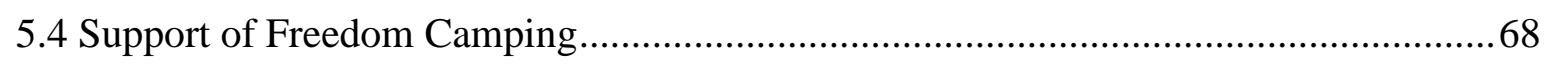

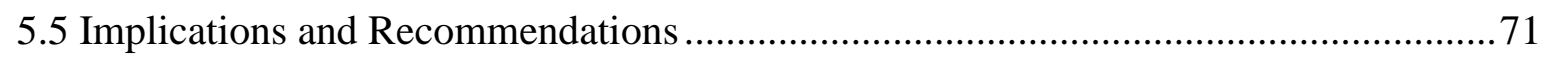

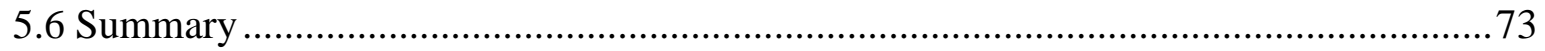

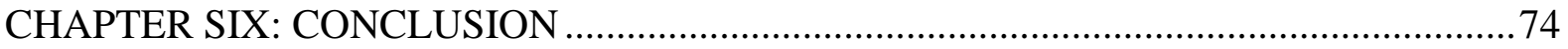

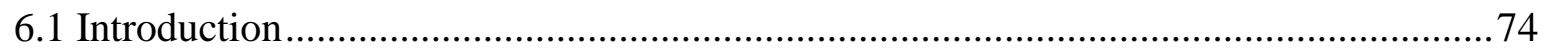

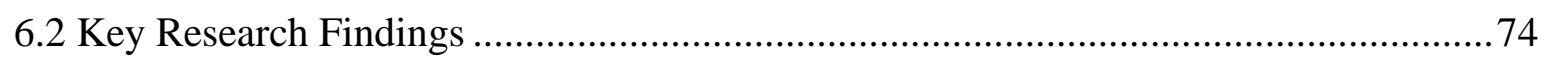

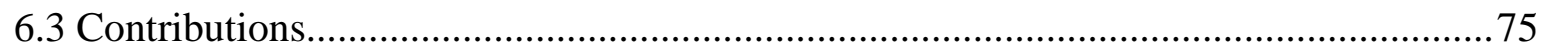

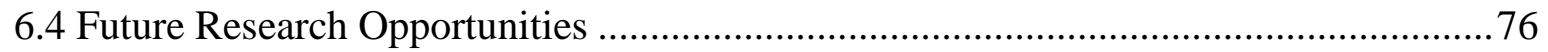

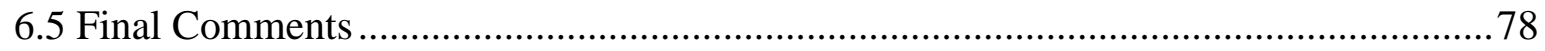

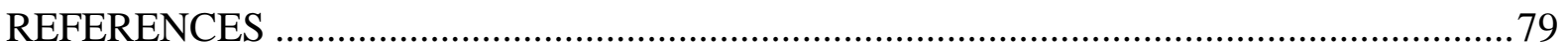

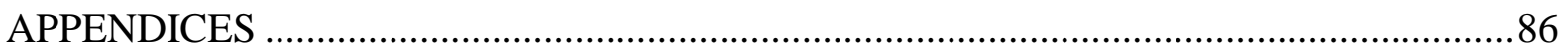

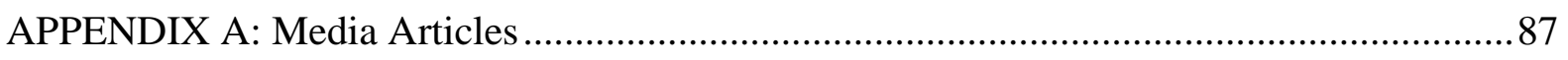

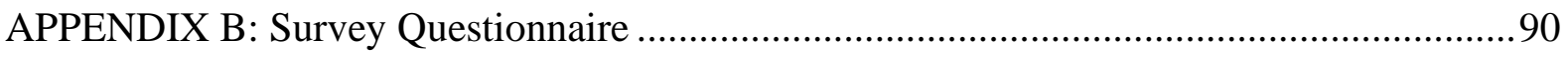

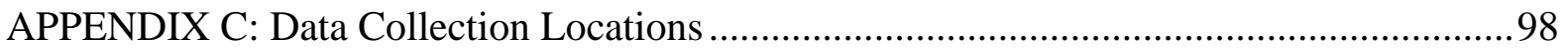

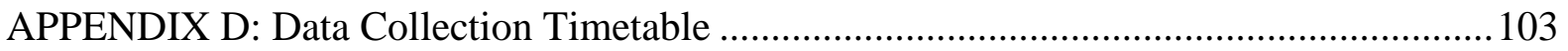

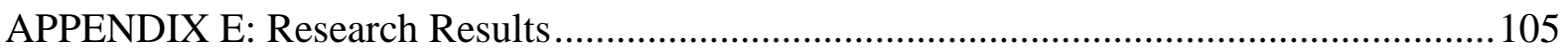

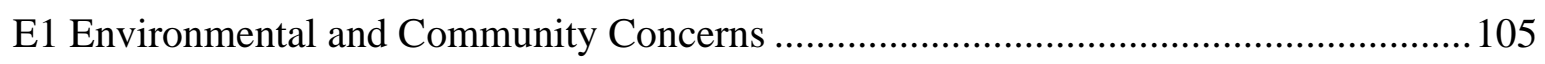

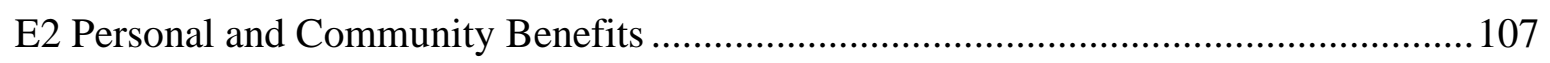




\section{LIST OF TABLES}

Table 2.1: Freedom Camping Definitions

Table 4.1: Sample Demographics 38

Table 4.2: Residency in Taupō District

Table 4.3: Demographic Comparison Between Sample and Taupō District Census Data 40

Table 4.4: Employment Relationship with Tourism 41

Table 4.5: Experience with Freedom Camping 41

Table 4.6: Characteristic Analysis of Groups $\quad 42$

Table 4.7: Freedom Camping Impacts 44

Table 4.8: Freedom Camping Support 47

Table 4.9: Freedom Camping's Impact on The Destination Image of Taupō District 49

Table 4.10: Impact on The Destination Image Across Employment Groups 49

Table 4.11: Desired Number of Freedom Campers and Tourists in the Taupō District 50

Table 4.12: Desired Numbers Across Employment Groups 51

Table 4.13: KMO and Bartlett's Test of Sphericity for Perceived Impacts 52

Table 4.14: Total Variance Explained

Table 4.15: Rotated Component Matrix with Loadings 54

Table 4.16: Reliability Statistics 56

Table 4.17: One-way ANOVA (Environmental and Community Concerns - Employment Relationship) $\quad 57$

Table 4.18: One-way ANOVA (Personal and Community Benefits - Employment Relationship) $\quad 58$ 


\section{LIST OF FIGURES}

Figure 1.1: New Zealand Districts and the Area of the Research 4

Figure 2.1: Number of Visitors Who Did Some Freedom Camping 13

Figure 2.2: Total Spend of Visitors Who Did Some Freedom Camping 13

Figure 2.3: Non-Self-Contained Freedom Camping Map: Prohibited Areas 16

Figure 2.4: Non-Self-Contained Freedom Camping Map: Open Areas 17

Figure 2.5: Literature Gap 24

Figure 2.6: Perceived Impacts of Freedom Camping Conceptual Model 25

Figure 3.1: Research Outline 26

Figure 3.2: Data Collection Locations 31

Figure 3.3: Analytical Framework 33

Figure 4.1: Respondents' Residential Locations in Taupō District 39

Figure 4.2: Scree Plot and Inflection Point 54

Figure 4.3: Component Plot in Rotated Space 56 


\section{LIST OF ABBREVIATIONS}

ANOVA $=$ Analysis of Variance

DIA $=$ Department of Internal Affairs

DoC $=$ Department of Conservation

$\mathrm{FCA}=$ Freedom Camping Act 2011

HEC-VUW = Human Ethics Committee of Victoria University of Wellington

$\mathrm{IVL}=$ International Visitor Conservation and Tourism Levy

IVS = International Visitors Survey

$\mathrm{KMO}=$ Kaiser-Meyer-Olkin

NZTA $=$ New Zealand Transport Agency

PCA $=$ Principal Component Analysis

$\mathrm{RCF}=$ Responsible Camping Forum

$\mathrm{SD}=$ Standard Deviation

SET $=$ Social Exchange Theory

$\mathrm{SLO}=$ Social Licence to Operate

SPSS $=$ Statistical Package for the Social Sciences

TIA $=$ Tourism Industry Aotearoa

$\mathrm{WOM}=$ Word of Mouth 


\section{CHAPTER ONE: INTRODUCTION}

\subsection{Introduction}

Chapter One begins with a brief presentation of the research background, research scope and location background to provide context for the research. Following this, the research aims are proposed, and the objectives outlined. Finally, the significance of the study and an outline of the research is presented.

\subsection{Research Background}

The activity of freedom camping is defined as a form of accommodation that enables tourists to stay overnight in designated public spaces, usually in a motor vehicle, for free or at minimal cost (Caldicott et al., 2014; Collins et al., 2018). Freedom camping has become a popular topic in recent times with significant media attention in New Zealand (Hammond, 2016; Schott, 2018). The number of international and domestic visitors participating in freedom camping in New Zealand is increasing (Angus \& Associates, 2017; MBIE, 2019 ${ }^{\mathrm{a}}$ ). However, like all tourist activities, freedom camping presents its own set of challenges due to the impacts that it can have on a destination.

Tourism impacts have been a focal point throughout tourism literature as they can influence the success of the industry in a given location. Tourism impacts can influence how host communities perceive tourism and dictate the level of support for its further development (Sinclair-Maragh \& Gursoy, 2005; Smallman \& Moore, 2010). Though the impacts of tourism on a destination are multifaceted they are commonly divided into socio-cultural impacts, environmental impacts, and economic impacts (Andereck et al., 2005; Liu \& Var, 1986; Tosun, 2002). These impacts can affect all stakeholder groups within a destination, such as the host community, public sector, private sector, not-for-profit sector, and tourists (Swarbrooke, 1999). Research recognises that the host community is an important stakeholder and integral to the success of tourism in a destination (Haywood, 1988). Therefore, if impacts that are perceived as negative by the host community are not dealt with, the host community can become hostile towards tourism, which can result in the industry losing its social licence to operate in a destination, and consequently fail.

Social exchange theory (SET) is the dominant theory used in tourism impact literature. SET is a sociological theory interested in understanding the exchange of resources in an interaction situation (Ap, 1992). SET suggests that an individual or group of people will 
willingly become involved in an exchange if they think that there will be a benefit from the exchange (Gursoy \& Kendall, 2006). When applied in the context of tourism impacts, SET suggests that those in the host community who benefit financially from tourism will have a more positive perception of its impact on the destination (Andereck \& McGehee, 2008; Ap, 1992; Boley et al., 2014). It is assumed these same principles will apply to the activity of freedom camping as, like tourism, it can have positive economic and socio-cultural impacts on a destination.

There has been little research thus far examining the impacts of freedom camping in New Zealand. To date, the study of freedom camping has been largely explored in the context of Australia (Caldicott et al., 2014) and literature regarding freedom camping based in New Zealand has predominately focused on the demand side and why tourists choose to freedom camp (Kearns et al., 2017). With the rise in popularity of visitors freedom camping in New Zealand, it is important to learn more about the perceived impacts that it may have on a destination. As the Taupō District is economically interested in its tourism sector, it is crucial to gain a deeper understanding of how the host community perceives the impacts of freedom camping, and mitigate any negative impacts so that the destination can continue to thrive.

\subsection{Scope of the Study}

This research is based in the Taupō District, New Zealand. Freedom camping, as with other forms of tourism, has impacts on all stakeholders in a destination. Freedom camping significantly impacts the public sector in a region, such as local authority or council, as they must act as the regulators of the activity and maintain the areas where it occurs. The private sector is also impacted by freedom camping, as it can act as both competition to businesses or as a supplementary activity, bringing money to the local economy through spending on goods and services. In a similar way, the host community in a destination may be affected by freedom camping occurring in their district. The host community is a complex and diverse group, that encompasses other stakeholders. For instance, an individual in the host community can also fit within other stakeholder groups such as the private, public, and non-for-profit sectors. As freedom camping is connected to the tourism industry, it is important to understand how the host community views the impacts of freedom camping and to what extent they support its operation. Thus, this research aims to understand the Taupō District host community's perceptions of the impacts of freedom camping. 


\subsection{Research Context}

The following sections contextualise the research by providing a comprehensive background of tourism and freedom camping in New Zealand, as well as in the Taupō District.

\subsubsection{Tourism and Freedom Camping in New Zealand}

The contribution of the tourism industry to the New Zealand economy is irrefutable. Tourism is New Zealand's leading export industry, contributing $20.4 \%$ of the country's total exports in the year ended March 2019 (Tourism Industry Aotearoa [TIA], 2019ª). Further, in that 12-month period, the tourism industry directly employed 229,566 people and indirectly employed an additional 163,713 people (Tourism New Zealand, 2019). With the growth of the tourism industry, international visitor numbers to New Zealand are increasing. In the year ending January 2020 international visitor arrivals reached 3.9 million (Stats NZ, 2020). Freedom camping is recognised as a form of tourism and in the years 2017-2018, approximately $3.4 \%$ of New Zealand's international visitors participated in some freedom camping (MBIE, 2019 ). Visitors who freedom camped had on average, a daily spend of $\$ 90^{1}$ and on average stayed a total of 46 nights. Due to the substantial length of time they spend in New Zealand, visitors who freedom camp have a higher average spend than the average of all other visitors (MBIE, 2019ª).

\subsubsection{Overview of the Taupō District}

The Taupo District is situated in the middle of the North Island of New Zealand and stretches from the town of Mangakino in the northwest, to the Tongariro National Park in the south, and east into Kaingaroa Forest. It spans across $6,350 \mathrm{~km}^{2}$ of land area and contains $610 \mathrm{~km}^{2}$ of lake area (see Figure 1.1 below). Statistics from the 2018 Census, count the population of the Taupō District at 32,907, which accounts for less than 1\% of the country's total population. The median age for the district is 41.3 years, being 3.9 years older than the national median age of 37.4 years. It also has a high percentage of people aged 65 years and over, with $19.0 \%$ of residents fitting into this bracket compared to $15.2 \%$ nationally. Taupo District has 11,118 Māori residents, which is $14.3 \%$ of the Māori population of New Zealand (Stats NZ, 2018). The majority of residents (83.1\%) in the Taupō District were born in New Zealand and of the remaining $16.9 \%$ born overseas, most were from the United Kingdom and Ireland (Stats NZ, 2018).

\footnotetext{
${ }^{1}$ All dollar figures displayed are in NZD.
} 
Figure 1.1: New Zealand Districts and the Area of the Research

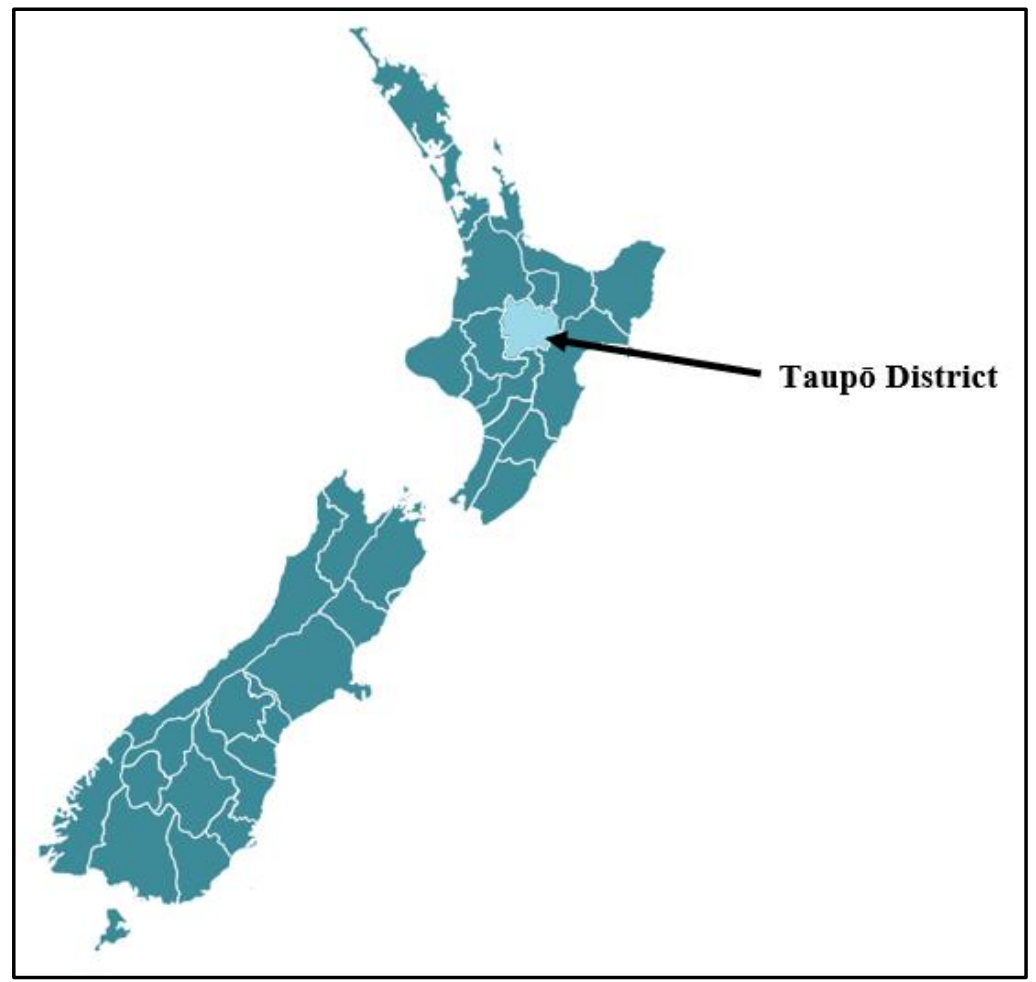

(Source: Adapted from Regional Tourism New Zealand, 2020)

\subsubsection{Tourism and Freedom Camping in the Taupō District}

The Taupō District is renowned for its natural attractions including Lake Taupō, which is Australasia's largest freshwater lake, natural thermal springs, and New Zealand's most visited natural attraction, the Huka Falls (Taupō District Council, 2020a ). Tourism is a major feature of the district's economy, contributing 14\% direct Gross Domestic Product (GDP) and directly employing $23 \%$ of the working age population (Taupō District Council, 2020a). Taupō District receives nearly a million visitors per year, with a large percentage of those visitors in the luxury tourism segment (Taupō District Council, 2020ª). In the year ended August 2019, Destination Great Lake Taupō (which encompasses the Taupō District) had a recorded annual domestic tourism spend of $\$ 464.6$ million, an increase of $6.7 \%$ from the previous year. The activity of freedom camping has grown in the district since the introduction of the Freedom Camping Act 2011. Over the years, media articles have shown there are public concerns about freedom camping in the Taupō District, with complaints of areas being overrun by freedom campers who are disrespecting the environment (Shand, 2016 ${ }^{\text {; }}$ McMichael, 2017). In 2017, as a response to these complaints, the Taupō District Council introduced the Freedom Camping Bylaw 2017 to set further restrictions on freedom camping in the district (Taupō District Council, 2017). 


\subsection{Research Aim and Objectives}

The purpose of this research is to fill the research gap regarding host community perceptions of freedom camping by applying the concept of SET to the perceived impacts of freedom camping within the context of the Taupō District, New Zealand.

The aim of the research is to understand the host community's perceptions of the impacts of freedom camping on the Taupō District. It also investigates these perceptions in the context of residents' employment relationship with tourism, and therefore their economic dependency on this industry, which is underpinned by SET (Lankford \& Howard, 1994). It is assumed that those who are employed in tourism will have the most positive perceptions of freedom camping's impacts. The research also aims to gain insights into the host community's overall support for the activity of freedom camping in Taupō District. To achieve these aims, the following objectives have been developed:

1. Determine how the host community of the Taupō District perceives the impacts of freedom camping.

2. Examine how these perceptions differ depending on the host community members' employment relationship with the tourism industry using SET. Four host community groups are identified for this purpose - those directly employed in tourism, those indirectly employed in tourism, those whose employment has no relation to tourism, and those not in employment.

3. Evaluate the host community's overall support of the freedom camping industry.

\subsection{Significance of the Study}

This exploratory study is the first to utilise perceived tourism impact items and SET and apply them to freedom camping to understand differing host community perceptions. Therefore, this study will contribute to the body of knowledge regarding freedom camping impacts in New Zealand, as freedom camping research is still an emerging area of tourism literature.

\subsection{Thesis Structure}

This thesis is divided into six chapters, with Chapter One the introduction.

Chapter Two provides a comprehensive overview of the relevant literature pertaining to the research area. It is separated into different sections to cover the topics of freedom camping, tourism impacts, social exchange theory, and stakeholder theory. The first section 
defines freedom camping and presents the different benefits and challenges that the activity can bring to the area in which it occurs. The second section details the differing impacts that tourism can have on a destination. The third section introduces social exchange theory and describes how an activity can be perceived based on its contributions to those whom it involves. The final section explains stakeholder theory and demonstrates why the support of a host community is integral for tourism to succeed in a destination. The research gap is identified through the examination of the literature. Lastly, a conceptual framework is presented, illustrating the connections between the aforementioned topics.

Chapter Three outlines the research methodology. The post-positivist research paradigm adopted in this study is described, followed by an explanation of the quantitative research approach employed. The questionnaire development and sampling technique are also explained. Following this, the ethics of the research is discussed in accordance with the Human Ethics Committee of Victoria University of Wellington. The data analysis methods are then outlined, accompanied by an analytical framework. Lastly, the research measures of validity, reliability, and generalisability are described, and the chapter finishes with an examination of the different limitations this research methodology entails.

Chapter Four introduces the research findings. It begins by analysing the sample population and the four employment groups and how these compare to census data for the Taupō District. Next, descriptive statistics for each of the impact items are examined. Following this, the overall support for freedom camping is evaluated. Finally, the items are grouped into components through a principal component analysis and one-way analysis of variance tests are conducted to test for statistical differences in perceptions of freedom camping between the different employment groups.

Chapter Five discusses the findings and examines them using the theories detailed in the literature review in Chapter Two. The chapter revisits the research objectives and uses them to shape the discussion. It identifies the key impacts the host community is most concerned about. Further, it investigates social exchange theory and deliberates on the perceptions of the four employment groups. Next, the support of freedom camping by the host community is evaluated. Lastly, the implications of the findings for both academia and the public sector, namely local council, and government, is explored. 
Chapter Six concludes the thesis by synthesising the key findings of the research and discussing the contributions this research offers. The chapter includes an explanation of limitations encountered in the research and subsequently identifies avenues for future research.

\subsection{Summary}

Chapter One has presented an overview of the research background, scope, and context. It identifies why this research is necessary and what it could contribute to the understanding of freedom camping impacts. Following a discussion of the research aims, the research objectives were developed, and the chapter concluded with an outline of the research.

\subsection{COVID-19 Impact}

It is important to note that this research commenced in July 2019 and the data collection was conducted during the months of November and December 2019, prior to the onset of the COVID-19 global pandemic. The COVID-19 pandemic is acknowledged briefly in the literature review in Section 2.3.4 and in the future research recommendations presented in Section 6.4, however, it will not be discussed throughout the rest of the thesis as it did not directly impact the data collection or analysis. 


\section{CHAPTER TWO: LITERATURE REVIEW}

\subsection{Introduction}

This chapter is divided into three sections which focus on the different components that contribute to understanding the perceived impacts of freedom camping, according to the host community. The first section discusses a broad overview of literature relating to freedom camping. It touches on the various definitions that are applied to the activity of freedom camping, and then examines freedom camping in New Zealand and within the Taupo District. It looks at historical trends related to freedom camping, the statistics about participation in freedom camping by both overseas visitors and domestic tourists, the resources that are committed to its management, and how freedom camping in the Taupō District has been portrayed in the media. The second section is dedicated to examining the literature detailing the perceived impacts that tourism can have on a destination. This is supplemented by introducing existing literature on perceived freedom camping impacts. The final section of this chapter relates to social exchange theory (SET) and stakeholder theory. The section outlines how groups in the host community may perceive the impacts of freedom camping differently based on their employment relationship with tourism, and therefore their economic dependency on the industry. The research gap identified through the literature is outlined and a conceptual framework illustrating the connection between the topics is presented.

\subsection{Overview of Freedom Camping}

Freedom camping is a form of accommodation with little to no cost, and involves selfdrive travellers using outdoor public spaces to camp. Internationally, synonyms for freedom camping include boondocking, street, low-cost, van, stealth, dry, and wild camping (Caldicott et al., 2014; Hardy et al., 2013). Whilst freedom camping is an established activity and growing in popularity, it is still in its infancy in academic examination. Hence, freedom camping has no single universally recognised definition. Existing literature and official New Zealand Government documentation provide various definitions or descriptions of the activity (see Table 2.1, below). However, all of these encompass the same concept of using of open or public spaces for overnight accommodation. 
Table 2.1: Freedom Camping Definitions

\begin{tabular}{|c|c|}
\hline Authors/Sources & Freedom Camping Descriptions and Definitions \\
\hline Caldicott et al., 2014, p.419 & $\begin{array}{l}\text { Freedom camping is the practice whereby domestic or international } \\
\text { travellers occupy, by deliberate choice, a recreational vehicle (RV) as a } \\
\text { mode of accommodation in an open space that is not bound by marketplace } \\
\text { commercial norms and camping and/or caravan park-based regulations. }\end{array}$ \\
\hline Collins et al., 2018, p.895 & $\begin{array}{l}\text { Freedom camping involves overnight stays in public open spaces - } \\
\text { typically using RVs such as campervans or caravans. }\end{array}$ \\
\hline $\begin{array}{l}\text { Department of Internal Affairs } \\
\text { (DIA), } 2016 \text {, p. } 9\end{array}$ & Freedom camping is a location specific camping activity without a fee. \\
\hline Kearns et al., 2017, p.395 & $\begin{array}{l}\text { Freedom camping is a form of tourism entailing overnight stays in open } \\
\text { spaces, rather than formal camping grounds. }\end{array}$ \\
\hline $\begin{array}{l}\text { Ministry of Business, } \\
\text { Innovation and Employment } \\
\text { (MBIE), } 2019^{\mathrm{a}}\end{array}$ & $\begin{array}{l}\text { Free camping - staying at a place that is NOT an official camp site, in a } \\
\text { tent, caravan, campervan/motorhome. (International Visitors Survey) }\end{array}$ \\
\hline Freedom Camping Act 2011 & $\begin{array}{l}\text { Freedom Camp means to camp (other than at a camping ground) within } \\
200 \mathrm{~m} \text { of a motor vehicle accessible area or the mean low-water springs line } \\
\text { of any sea or harbour, or on or within } 200 \mathrm{~m} \text { of a formed road or a Great } \\
\text { Walks Track, using one or more of the following: a tent or other temporary } \\
\text { structure, a caravan, a car, campervan, housetruck or other motor vehicle. }\end{array}$ \\
\hline
\end{tabular}

\subsection{Freedom Camping in New Zealand}

Freedom camping is recognised as having a long history in New Zealand and is undertaken by a variety of travellers, including both domestic tourists and international visitors (Collins et al., 2018; MBIE, 2018). It is increasing in popularity within the context of New Zealand and is valued by tourists because it facilitates flexible and spontaneous travel, giving the ability to stay within, and explore, remote and scenic landscapes (Graefe \& Dawson, 2013).

According to Brooker and Joppe (2013) outdoor hospitality, including the likes of camping and caravanning, is experiencing increased demand globally. The activity of camping has long been embedded into the New Zealand culture, with coastal areas being the prominent 
location of choice (Collins \& Kearns, 2010; Collins et al., 2018). A survey conducted by the Department of Conservation (DoC) (2006) showed that $80 \%$ of New Zealanders have visited a caravan or holiday park at least once in their lifetime. Freedom camping had been recognised as the norm in New Zealand up until the 1950s, when the creation of formalised camping grounds increased due to various pressures, such as public health concerns, population increase, and heightened coastal residential property development (Collins \& Kearns, 2010).

Nowadays, the act of freedom camping is a contested issue in New Zealand between different stakeholder groups. Communities, tourists, and government all have different perceptions of freedom camping's value based upon their interests (Caldicott et al., 2018; Fieger et al., 2019). The idea of freedom camping being a polarising topic is illustrated by Caldicott et al. (2014), who introduces the various views people have about freedom camping. Caldicott et al. (2014, p.418) state that some people view freedom camping as an illegal, destructive and parasitic' activity, and others as a 'lifestyle choice', or even as a necessity due to the rising prices of commercial campgrounds. Growing concerns are being expressed about freedom camping's social, environmental, and economic consequences (Collins et al., 2018). Throughout the summer period of 2015-2016, freedom camping was widely discussed in the New Zealand media, with stories of rubbish, congestion, and offensive behaviour (Hammond, 2016). Most popular camping spots are located on council reserves, and many of the problem spots that received media attention were located alongside the state highways (New Zealand Transport Agency [NZTA]) or DoC owned land. Hammond (2016) argues that the Government has historically supported the activity of freedom camping but has not invested in the necessary facilities required to maintain it. Communities in the areas where freedom camping regularly occurs are now questioning how DoC and NZTA will fund the required infrastructure for nonself-contained freedom camping.

Legislation addressing the activity of freedom camping was introduced in New Zealand, prior to the start of the 2011 Rugby World Cup. The Freedom Camping Act 2011 (FCA) enables freedom camping to be controlled and managed better, as many New Zealanders were concerned about protecting their right to freedom camp (MBIE, 2018). The FCA also empowers local councils to introduce bylaws that restrict or prohibit freedom camping in designated areas, where required to prevent adverse effects (Collins et al., 2018). According to 
the FCA, freedom camping is permitted in any Local Authority area and conservation land ${ }^{2}$ unless the area is restricted or prohibited through bylaws or under another enactment. The FCA is focused on government-controlled land and therefore does not extend to freedom camping in remote backcountry public spaces or on private land, such as farms. If someone does not adhere to the rules and restrictions of the FCA, they can face various fines. Penalty fees for not adhering to the rules and regulations of the FCA range depending on the severity of the offence committed and the general fee is $\$ 200$.

\subsubsection{Freedom Camping Bylaws}

Under the Freedom Camping Act 2011 (FCA), local authorities can make bylaws that define where in a district or region freedom camping is restricted or prohibited. However, the bylaws must meet the criteria outlined in the FCA and be necessary for one or more of the following purposes: to protect the area, to protect the health and safety of those who may visit the area, and to protect access to that area. It must also be considered the most appropriate and proportionate way of addressing the perceived problem in relation to that area and must be consistent with the New Zealand Bill of Rights Act 1990. Further, the restricted or prohibited areas must be defined in either a description of locality or a map. Under the FCA, prohibitions and restrictions are intended to be exceptions, rather than the rule. This is illustrated by the fact that bylaws are unable to absolutely prohibit freedom camping in a region (Freedom Camping Act 2011).

\subsubsection{New Zealand Freedom Camping Statistics}

Statistics on the activity of freedom camping in New Zealand are recorded in the International Visitor Survey (IVS), which is a survey that provides information on the characteristics, behaviour, and expenditure of international visitors (MBIE, 2019 $)$. The survey assesses the extent of freedom camping by international visitors in New Zealand through two measures; the number of visitors for whom freedom camping was their primary form of accommodation, and the number of visitors who freedom camped at least once. The IVS also contains information on other activities that visitors undertook, which in turn can indicate their economic contribution.

\footnotetext{
${ }^{2}$ A Local Authority area is an area of land that is within the district or region of a Local Authority and is controlled or managed by that authority under any enactment. Conservation land refers to an area of land that is controlled or managed by the Department of Conservation under a conservation Act. Both areas do not include areas of land that are permanently underwater (Freedom Camping Act 2011).
} 
Data from the IVS shows that the number of international visitors participating in some freedom camping in New Zealand has increased from 54,000 in the year ended 2013 to around 123,000 in the year ended 2018, thus accounting for approximately 3.4\% of New Zealand's international visitors in 2017 and 2018 (MBIE, 2019 ) (shown in Figure 2.1). When reviewing data from the IVS between 1997-2018, international visitors who use freedom camping as their primary source of accommodation only accounted for $0.8 \%$ of all visitors (Fieger et al., 2019). The total estimated spending by visitors who participated in some freedom camping while in New Zealand has also seen a significant increase in between 2013 and 2018, from \$210 million in 2013 to $\$ 540$ million in 2018 (MBIE, 2019 ) (shown in Figure 2.2). They are reported as having an average daily spend of $\$ 90$, less than half the amount spent by all visitors $(\$ 190)$. However, they tend to have a higher spend overall as they stay for longer. In 2017, the average length of stay for visitors who did some freedom camping was 46 days, which is almost three times longer than the average of all other visitors (17 days) (MBIE, 2019ª).

When looking at the activity of freedom camping in New Zealand, it is often the international tourists who are perceived by the locals as being the freeloaders and the ones who violate camping practices (Fieger et al., 2019; Kearns et al., 2017). Challenging this perception is a study released by Fieger et al. in 2019 on the economic contribution of international freedom campers to New Zealand, dating from 1997-2018, using the IVS. The study compared those who listed their primary accommodation as freedom camping with tourists staying in other accommodation. Fieger et al. looked at freedom campers' engagement in both low value activities, which are activities that are either free (e.g. hiking) or below $\$ 100$ (e.g. museum visits), and high value activities that are over $\$ 100$ (e.g. bungy jumping). The results of the study found that while freedom campers had a higher engagement in free activities in comparison with tourists staying in motels, hotels and luxury accommodation, they had a similar level of engagement in high value activities to tourists who were recorded as staying in homestays, B\&Bs, and campsites/national parks. Furthermore, freedom campers had a higher engagement in high value activities than tourists staying in private accommodation, such as those staying with friends or family. Fieger et al.'s study therefore disputes the perception that freedom campers are cheap tourists through showing their valid economic contribution to the New Zealand economy. 
Figure 2.1: Number of Visitors Who Did Some Freedom Camping

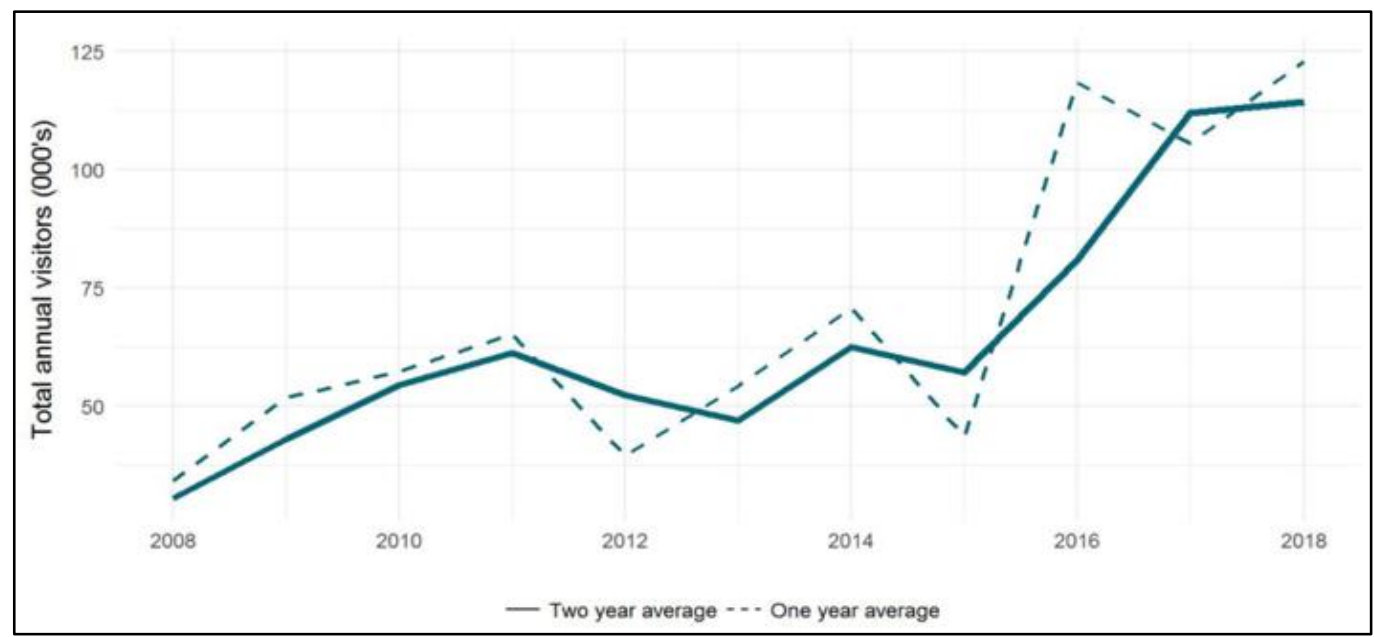

Source: MBIE (2019)

Figure 2.2: Total Spend of Visitors Who Did Some Freedom Camping

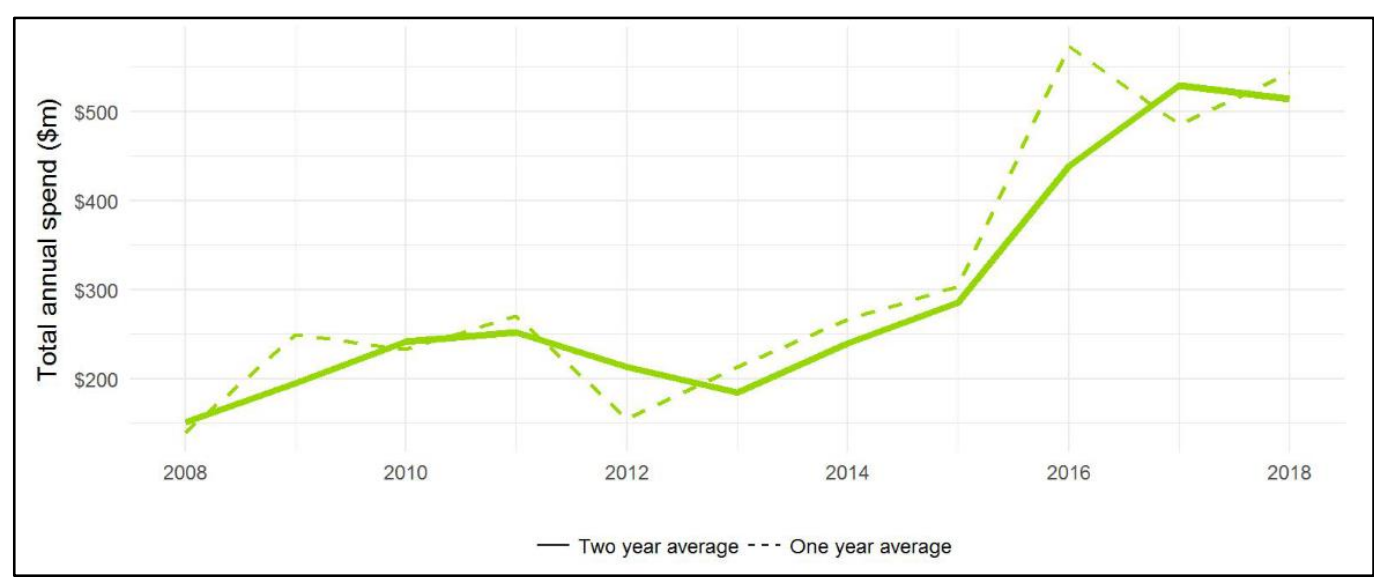

Source: MBIE (2019)

In the context of domestic freedom camping, a Visitor Insights Programme produced by Angus \& Associates (2017) found that between 2014 and 2016, approximately 1\% of domestic tourists used freedom camping as their primary mode of accommodation. In conjunction with this, they also found that between 2013 and 2017 the number of New Zealand Motor Caravan Association memberships increased by almost 20\%, reaching 71,500 members. These findings demonstrate that freedom camping is growing in popularity for domestic tourists, as well as international visitors. Freedom camping's popularity is connected to its ability to offer visitors greater autonomy with their travels. It allows them access to natural and isolated sites, which provides the opportunity for simpler and more self-sufficient leisure (Kearns et al., 2017). 


\subsubsection{New Zealand Freedom Camping Funding and Resources}

In 2007 the Responsible Camping Forum (RCF) was set up by Tourism Industry Aotearoa (TIA). It now has approximately 60 members, consisting of both private sector participants and local government. The central aim of the RCF is to help manage the community, social, and environmental issues that arise from freedom camping (TIA, 2019 ${ }^{\mathrm{b}}$ ). As an extension of the RCF, in 2018 the Responsible Camping Working Group was established as a partnership between industry, the Government and local governments.

In May 2019, Tourism Minister Kelvin Davis announced that an additional \$8 million would be added to the existing $\$ 8.5$ million Responsible Camping Fund, to help encourage responsible camping across New Zealand (TIA, 2019 ${ }^{\mathrm{b}}$ ). The $\$ 16.5$ million total funding was split across New Zealand's 16 regions to enable local councils to invest in temporary facilities for the busy summer period. The Waikato region, which includes the Taupō District, received $\$ 2,462,026$ worth of funding, placing it as the third highest funded region behind the West Coast $(\$ 3,103,372)$ and Canterbury $(\$ 2,539,455)\left(\right.$ MBIE, 2019 $\left.{ }^{b}\right)$. The Taupō District Council received $\$ 145,852$ from the fund for $2019 / 20$ summer period. This money was dedicated to the servicing of toilets and dishwashing stations, and directional signage (MBIE, 2019 ${ }^{\mathrm{b}}$ ). In addition to the creation of temporary facilities, the money was also to be used to cover operational costs such as education, enforcement, and ambassadors' programmes (Cropp, 2019).

The fund also supported the introduction of new initiatives nationwide, such as the installation of artificially intelligent solar-powered cameras to ten freedom camping sites. Through the CamperMate App, these cameras show potential freedom campers if their desired camping spot is full, to reduce overcrowding in popular areas (Radio New Zealand, 2019). A pilot for this initiative was undertaken in 2018 and its results showed that $90 \%$ of campers opted for a different campsite once finding that their first choice was at maximum capacity. Technology such as this therefore helps reduce the strain of physically monitoring the various campsites and discourages unwanted behaviours. Other initiatives included a new app to help camping ambassadors provide advice to campers, more funding for a Tourism New Zealand education campaign, and free access for campers to check the New Zealand Standard for selfcontained vehicles, which had previously cost $\$ 70$. 


\subsubsection{Freedom Camping and Public Awareness}

The COVID-19 global pandemic has had an unprecedented impact on New Zealand's tourism industry. When looking at rebuilding the industry post-pandemic, questions are being asked about the legitimacy of freedom camping. In late April 2020, during New Zealand's COVID-19 Alert Level 4 lockdown, tourism worker, Jennifer Branje, launched a petition to Parliament to ban all freedom camping for non-residents nation-wide, in support of New Zealand tourism providers (Carroll, 2020). In the first week after its launch, the petition gained more than 1500 signatures. The petition was set to finish on $31^{\text {st }}$ July 2020 however, it was withdrawn in May after Branje received violent threats by members of the public. At the time of withdrawal, it had amassed 8000 signatures (Carroll, 2020; Stuff, 2020). This petition, and the public interest it generated, suggests that even with disruptions from COVID-19, the activity of freedom camping remains a divisive topic for the tourism industry. Thus, emphasising the need to gain a greater understanding of the impacts of freedom camping.

\subsection{Freedom Camping in the Taupō District}

Freedom camping in the Taupō District has been receiving additional attention since the Freedom Camping Act 2011 was created. In 2017, a bylaw was introduced by the Taupō District Council to address the community's concerns about freedom camping in the region. Issues regarding freedom camping tend to arise at a designated site when there are a multitude of activities contending for the same area, such as camping, walking, and fishing. According to DoC (2017), for freedom camping to succeed there needs to be a balance between managing the environmental and recreational values of a site. Media articles detail the tumultuous relationship that freedom camping has had with the Taupō District over recent years (listed in Appendix A). Numerous articles detailed the issues of freedom campers defecating in reserves, using waterways to wash their clothing, inhabiting streets, and leaving rubbish behind at locations they have stayed in (Kirkeby, 2016; McMichael, 2017; Shand, 2016 ${ }^{\text {a }}$ Shand, 2017). Further, the media reported repeated complaints about Hipapatua/Reid's Farm Recreation Reserve, and in December 2017 three DoC freedom camping sites were closed (DoC, 2017; Shand, 2016 ${ }^{\mathrm{b}}$ ). Between December 2017 and February 2018, there were 75 fines issued to freedom campers who broke the bylaw (Steven, 2018). However, media coverage of freedom camping has not been all negative. In 2017, the township of Mangakino was reported as expressing their support of freedom camping and proposing six new freedom camping sites (Steven, 2017). 


\subsubsection{Taupō District Council Freedom Camping Bylaw 2017}

The 2017 Freedom Camping Bylaw includes specific areas in the Taupō District where freedom camping is prohibited. One of the most notable prohibited areas is Ferry Road, Taupō, which was originally opened as a freedom camping spot for self-contained vehicles in 2011, but due to public pressure was included in the 2017 Bylaw (Taupō District Council, 2017).

Figure 2.3: Non-Self-Contained Freedom Camping Map: Prohibited Areas

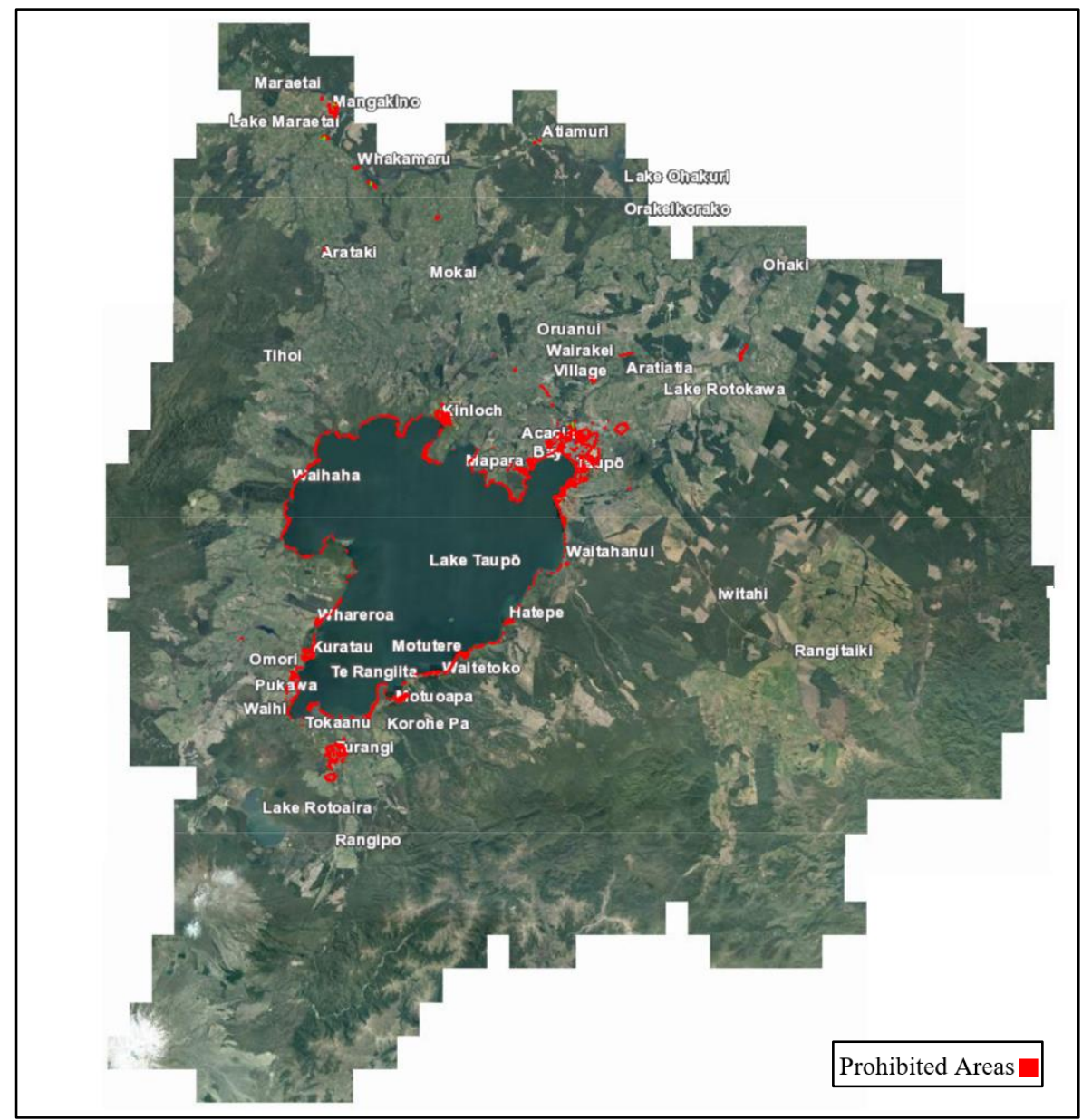

Source: Taupō District Council (2017)

The Bylaw also states that an individual may freedom camp in any local authority area in a self-contained vehicle ${ }^{3}$, which must comply with New Zealand Standard Self Containment of Motor Caravans and Caravans (Taupō District Council, 2017). Self-contained vehicles must display a current self-containment warrant to show that they meet the New Zealand Standard. All non-self-contained freedom camping is restricted to the open freedom camping areas

\footnotetext{
${ }^{3}$ Self-contained vehicles are defined in the Bylaw as, ' a vehicle designed and built for the purpose of camping which has the Self-contained capability of meeting the ablutionary and sanitary needs of occupants of that vehicle for a minimum of three days without requiring any external services or discharging any waste' (Taupō District Council, 2017).
} 
outlined; Hipapatua/Reid's Farm Recreation Reserve, Mangakino Recreation Reserve, Whakamaru Domain and Whakamaru Recreation Reserve, shown in Figure 2.4. Unless otherwise stated, freedom camping in Taupō District is limited to a maximum of three nights/four days and if an individual is asked to move by an enforcement officer, they must relocate at least 500 metres away from their original site.

Figure 2.4: Non-Self-Contained Freedom Camping Map: Open Areas

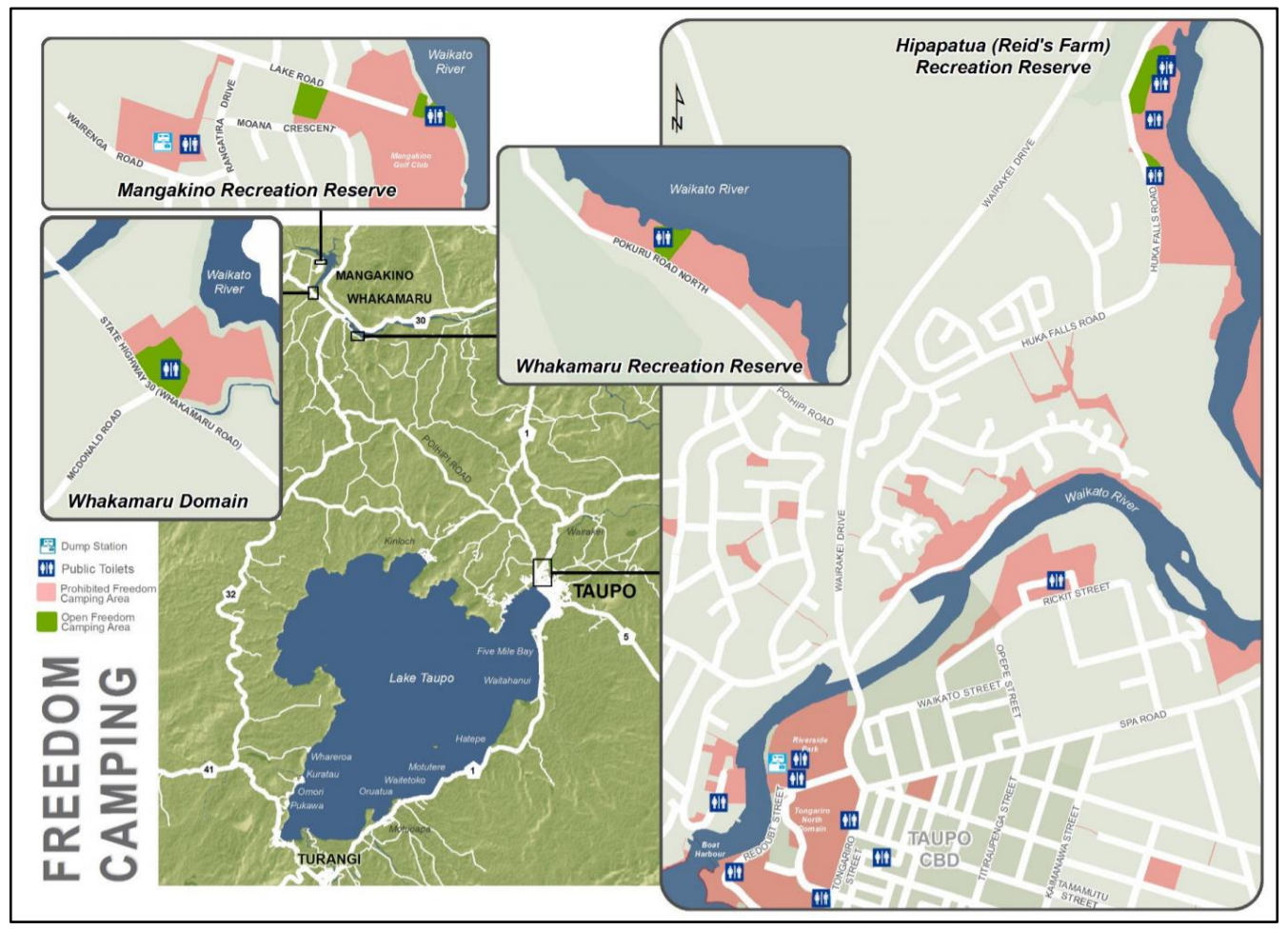

Source: Taupō District Council (2017)

\subsection{Tourism Impacts}

Tourism is a global industry that produces a multitude of impacts in destinations. These impacts can influence how host communities perceive the tourism industry and dictate their support for its further development (Sinclair-Maragh \& Gursoy, 2005; Smallman \& Moore, 2010). The impacts of tourism on a destination are multifaceted. In an attempt to analyse and understand these impacts in greater detail, prior studies have categorised tourism impacts into three core groups; socio-cultural impacts [henceforth referred to as social impacts], environmental impacts, and economic impacts (Andereck et al., 2005; Liu \& Var, 1986; Tosun, 2002). Tosun (2002) suggests that economic impacts from tourism development are perceived as mostly positive as they can benefit the host community financially. Further, residents are likely to oppose tourism development if they consider the costs of tourism to outweigh the benefits (Nunkoo \& Gursoy, 2012). 


\subsubsection{Social Impacts}

The social impacts of tourism are the result of the interaction between the host community and the tourists (Smith, 1995). Moreover, the social impacts from tourism can be seen as the 'people impacts', which focuses on both changes in the everyday quality of life of the host community, and any cultural impacts (Okech, 2010). The perceived negative social impacts as a result of tourism include increased crime (Andereck et al, 2005; Brunt \& Courtney, 1999; Dogan, 1989; Lankford, 1994; McCool \& Martin, 1994; Tosun, 2002), disruption to the peace and tranquillity of recreational parks, maximum capacity being reached on public infrastructure, congestion, and declining resident hospitality (McCool \& Martin, 1994; Liu \& Var, 1986; Zmyślony et al., 2020). Tourism can also create friction between the community and tourists (Andereck et al, 2005; Dogan, 1989; McCool \& Martin, 1994). It can result in impacts affecting the host community's day to day life, such as corporate developments that are deemed to damage the social fabric of local communities (Zmyślony et al., 2020). However, it is also recognised in the literature that there can be positive social impacts associated with the development of tourism in a destination. Tourism has the ability to enhance the cultural identity of a destination through the encouragement of cultural activities and improved cultural heritage (Andereck et al., 2005; Brunt \& Courtney, 1999; McCool \& Martin, 1994). It also offers the host community an opportunity to interact with other cultures, and therefore expose themselves to new perspectives, and increase intercultural communication and understanding (Andereck et al., 2005; Liu \& Var, 1986).

\subsubsection{Environmental Impacts}

The potential environmental consequences of tourism have been examined throughout literature. A key environmental impact highlighted is pollution, from vehicles and tourists, and encompasses rubbish, noise pollution, air pollution, and water pollution (Andereck et al, 2005; Lankford, 1994; Liu \& Var, 1986; Okech, 2010). Furthermore, there can also be damage to geological formations in the destination, through erosion or acts of vandalism (Andereck et al, 2005), along with the destruction of property (Liu \& Var, 1986), and disruption to the destinations natural habitat, which can lead to the disappearance of wildlife (Andereck et al., 2005; Liu \& Var, 1986). Additional negatively perceived environmental impacts highlighted in the literature include litter (Andereck et al, 2005; Brunt \& Courtney, 1999; Lankford, 1994; Liu \& Var, 1986; Okech, 2010), overcrowding, particularly in places such as outdoor recreation facilities and public infrastructure (Andereck et al, 2005; Dogan, 1989; Johnson et al., 1994; 
Liu \& Var, 1986; McCool \& Martin, 1994; Okech, 2010; Sheldon \& Var, 1984), pedestrian congestion (Brunt \& Courtney, 1999), and traffic and parking problems (Andereck et al, 2005). Alternatively, tourism can bring positive environmental impacts, such as the preservation of historical buildings and landmarks (Liu et al., 1987). Furthermore, tourism has the ability to encourage and enhance conservation in nature areas (Andereck et al., 2005; Budowski, 1976).

\subsubsection{Economic Impacts}

Residents generally view the economic impacts of tourism positively, due to the industry's financial contributions to their community (Andereck et al., 2005). The economic impacts of tourism highlighted in literature include personal benefits, such as improved personal income (Andereck et al, 2005; Haralambopoulos \& Pizam 1996; Lankford, 1994), job creation, and employment opportunities (Andereck et al, 2005; Lankford, 1994; Liu \& Var, 1986; Johnson et al., 1994), and improved standard of living (Andereck et al, 2005; Lankford, 1994; Johnson et al., 1994; McCool \& Martin, 1994). Broader positive economic impacts identified include benefits to local businesses (Liu \& Var, 1986; McCool \& Martin, 1994) and economic diversity (Andereck et al, 2005). There are few negative economic impacts mentioned, however, some studies suggest that tourism can also lead to an increased cost of living, as a result of greater demand for goods, services, land, and housing, which is detrimental to those living within the tourism destination (Andereck et al, 2005; Liu \& Var, 1986).

\subsubsection{Freedom Camping Impacts}

The activity of freedom camping is described by Hardy et al. (2013, p.6) as being ' $a$ great challenge facing the tourism industry' due to its varied potential impacts. The infrastructure required to facilitate freedom camping has implications for local councils, who are progressively becoming more involved in the management of freedom camping sites, and also for private campground owners, who may lose business as a result of freedom camping. It is recognised that management dilemmas can occur for the councils where freedom camping frequently occurs in a concentrated area. Alternatively, there are also potential positive impacts from the activity. Freedom camping sites have the ability to attract visitors to more isolated regions, which visitors may not have otherwise stayed in overnight. Therefore, freedom camping helps to disperse visitor expenditure away from popular tourism locations and contributes to local economic development in more remote areas (Collins et al., 2018; Hardy et al., 2013). 
In many instances, designated non-self-contained freedom camping sites lack the necessary facilities for people to stay at them. Often there may be no access to clean water, a lack of rubbish bins, no toilets, and inadequate facilities to dispose of human waste. The absence of these facilities can result in litter and waste being left behind, which may cause pollution in the area (DIA, 2016). These concerns are reflected in research by Angus and Associates (2017), which reported that the biggest complaints in relation to freedom camping in recent years include littering, incorrect wastewater disposal, and human defecation.

The spaces where freedom camping occurs may become sites of contest, or even conflict, depending on how the community responds to the practice. Collins et al. (2018, p.896) report that when freedom camping occurs near residential areas, and is visible or audible to the residents, they may perceive it as being 'a threat to locally constituted notions of propriety and property'. As such, there have been a variety of concerns expressed about the consequences of freedom camping. Collins et al. (2018) state that freedom campers themselves are commonly linked to a variety of behaviours that are considered both antisocial and harmful, such as leaving excrement on roadsides and in reserves, along with causing other adverse environmental effects. Impacts mentioned include parking congestion, noise, sewage, waste, the lighting of illegal fires, over-running public facilities, and undercutting campgrounds ability to contribute to local economies (Collins et al., 2018, p.898). Furthermore, freedom camping may be viewed by some as freeloading, and draining community resources, without contributing to the local economy. Those who hold this view perceive freedom camping as being a low-cost activity and therefore not beneficial to the areas in which it occurs.

\subsection{Social Exchange Theory}

Social exchange theory (SET) is a theory originating from the disciplines of sociology and social psychology (Boley et al., 2014). Initial work on SET was undertaken by Emerson (1976) to analyse human behaviour. Emerson (1976, p.336) summarised it as 'a two-sided, mutually contingent, and mutually rewarding process involving 'transactions' or simply 'exchange'. Subsequent to this, the concept of SET was further developed by Homans (1985, p.606), who conjectured that 'social behavior is an exchange of goods, material goods but also non-material ones, such as the symbols of approval or prestige'.

Perdue, Long and Allen (1987) were the first to suggest the application of SET to tourism, as a potential basis for understanding why residents support or oppose tourism 
development in a destination (Boley et al., 2014). The theory was then explicitly discussed by Ap (1992, p.685), who found SET to be beneficial in a tourism context due to both its logical nature and its ability to account for 'both the positive and negative impacts of tourism as perceived by the host community'. The theory is defined by Ap (1992, p.668) as 'a general sociological theory concerned with understanding the exchange of resources between individuals and groups in an interaction situation'. SET suggests that an individual, or group of people, will willingly become involved in an exchange with another party if they think that there will be a benefit from the exchange (Gursoy \& Kendall, 2006). SET is now recognised as the dominant theory used to study residents' perceptions of tourism impacts based upon their awareness, attitude, and intention (Ap, 1992; Boley et al., 2014). The popularity of SET is credited to its recognition of the heterogeneous nature of a host community (Nunkoo et al., 2013). Although SET has been widely used in tourism research, it has not yet been used to analyse the activity of freedom camping and therefore it is unknown if the same principles apply.

According to Andereck et al. (2005, p.1061), when applying SET in the context of tourism it is theorized that, 'an individual's attitudes toward this industry, and subsequent level of support for its development, will be influenced by his or her evaluation of resulting outcomes in the community'. This coincides with other studies on resident perceptions of tourism impacts, which have shown that residents who are dependent on the industry, or perceive a greater level of economic gain or personal benefit from it, tend to have more positive perceptions of tourism impacts than others (Brunt \& Courtney, 1999; Haralambopoulos \& Pizam, 1996; Lankford \& Howard, 1994; Liu \& Van, 1986; Tosun, 2002). Tosun (2002, p.233) illustrates this by stating, 'residents benefiting from tourism have a higher level of support for it and thus report more positive impacts. 'Within existing tourism literature, there are a number of studies that conclude that residents who benefit economically from tourism tend to hold a more favourable attitude towards the impacts than those who receive fewer or no benefits (Boley et al., 2014; McGehee \& Andereck, 2004). In the context of freedom camping it is also therefore assumed that those who are employed in tourism will have the most positive perceptions of freedom camping's impacts, as freedom camping also generates expenditure in a destination (Fieger et al., 2019).

\subsection{Stakeholder Theory}

Stakeholder theory is frequently used in tourism research. The term 'stakeholder' simply refers to, 'any individual or identifiable group who is affected by, or who can 
affect the achievement of corporate objectives' (Ryan, 2002, p.20). In tourism, stakeholders are described as any individual or group which is involved in, interested in, or affected either positively or negatively by tourism activities (Aas et al., 2005). Swarbrooke (1999) divided tourism stakeholders into five groups; government, tourists, host communities, tourism businesses, and other sectors. Robson and Robson (1996), claim that a core principle of stakeholder theory is that organisations that are active within a community have a 'social contract' with that community. This social contract must be maintained, otherwise there may be conflict, leading to the loss of tourism's social licence to operate (SLO), and thus making it difficult for the industry to continue operating within that community. It is important to consider the concept of SLO in an impact assessment, as the extent to which an activity is regarded as socially acceptable will affect how it is experienced, namely, the impact it will have (Dare et al., 2014). Ultimately, it is recognised that to achieve a sustainable tourism industry, the host community must be supportive of tourism (Andereck \& Vogt, 2000; Andriotis, 2005; Ap, 1992).

Several studies have explored the perceptions and attitudes of individual stakeholder groups, acknowledging their role in the process of tourism development (Andereck \& Vogt, 2000; Brunt and Courtney, 1999). Comparisons of stakeholder groups have revealed there are differences in the perceptions and attitudes of tourism between various groups: residents and tourists (Puczko \& Ratz, 2000); residents and entrepreneurs (Andriotis, 2005; Pizam, 1978); residents, entrepreneurs, and tourists (Kavallinis \& Pizam, 1994); residents, entrepreneurs, and governmental officials (Lankford, 1994), and residents, entrepreneurs, government officials, and tourists (Byrd, Bosley \& Dronberger, 2009).

In this research, the primary stakeholder group being examined is the residents, also referred to as the host community. Previous research has examined differences in residents' perceptions of tourism impacts based on their economic relationship with tourism. Andriotis (2005) compared perceptions based on 'reliance on tourism' and divided the community into the three groups; tourism business people, residents reliant on tourism employment, and residents who are non-reliant on tourism. As described in Section 2.6, those who have higher levels of engagement with the tourism industry, such as employment in it, are more positively inclined towards tourism, and are therefore more likely to express positive views towards its impacts (Andereck \& McGehee, 2008). 


\subsubsection{Host Community}

The connections between the host community in a destination and tourism development has been a key research topic in tourism literature. The host community is defined by Swarbrooke (1999) as 'all those who live within a tourist destination'. This definition groups individuals by their geographic location in relation to a tourism destination, rather than their common interest or concerns. Ryan (2002, p.21) explains that 'host communities are far from homogenous', and while some host community members will recognise the entrepreneurial opportunities that tourism brings, others will remain impartial to the industry, and some may even feel animosity towards it.

The importance of the host community is emphasised by Haywood (1988, p.105), who states, 'healthy, thriving communities are the touchstone for a successful tourism industry'. However, he notes that the substantial development, income, and activity that tourism generates may not always be compatible with a community's other social and economic objectives. Moreover, Haywood emphasises that 'whenever the residents' thresholds of tolerance for tourism and tourists are exceeded, host-tourist encounters sour, and the industry has a tendency to peak, fade, and self-destruct'. Furthermore, tourism is recognised as being a sustainable practice when it adapts to the destination's community and their locally defined set of norms (Vincent \& Thompson, 2002). As freedom camping is a form of tourism it therefore is assumed that these same concepts about the host community's relationship with tourism will also translate into the host community's relationship with freedom camping.

\subsubsection{Host Community Perceptions and Attitudes to Tourism}

Initial studies on resident perceptions and attitudes towards tourism were impact focused and had questionnaires pertaining to various impacts that tourism may cause, with some specifically focusing on environmental or social impacts (Andereck \& Vogt, 2000). Researchers completing these studies adopted either an 'attitudes' or a 'perceptions' approach, however there is no clear distinction between these two approaches, as they predominantly use the same types of measures. Most of the prior studies used agreement scales to measure the attitudes towards tourism or the perceptions of impacts (Andereck \& Vogt, 2000). Residents in previous tourism attitude studies commonly reported positive attitudes towards economic improvement, improved quality of life, improved appearance, encouragement of cultural activities, and more recreation and park opportunities due to tourism (Andereck \& Vogt, 2000). 


\subsection{Literature Gap}

There is limited existing literature on the topic of freedom camping, and it has not been shown whether existing theories and findings about tourism can be applied to this activity. However, there is an evident need to gain a greater understanding of freedom camping impacts on a destination and to what extent freedom camping is accepted by the host community. This research aims to fill the literature gap on perceptions of freedom camping by applying the concepts of social exchange theory and the perceived impacts of tourism to the host community of the Taupō District, see Figure 2.5, below.

Figure 2.5: Literature Gap

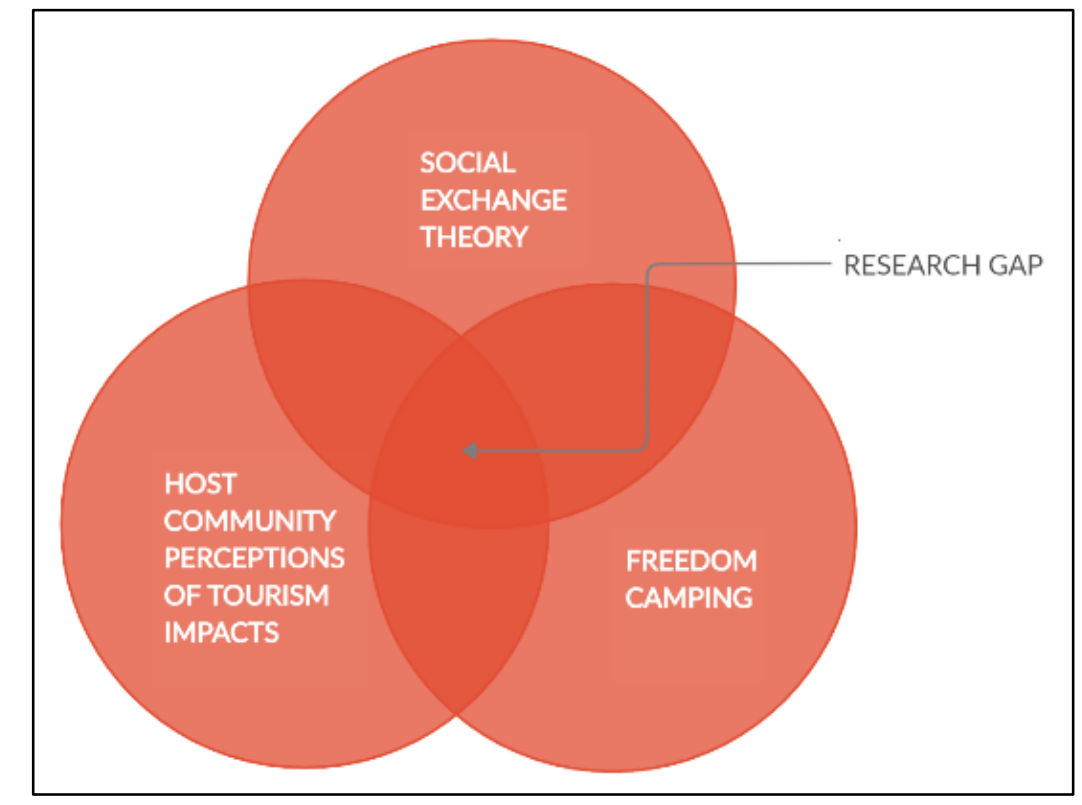

\subsection{Conceptual Framework}

A conceptual framework is a key part of research design as it is a system of assumptions, beliefs, concepts, expectations, and theories that supports and informs the research (Maxwell, 2012). It assists in shaping the research design through helping to identify, define, and operationalise the key concepts that are going to be studied, and the assumed relationships between them (Pearce, 2012). The conceptual framework presented in this study (see Figure 2.6) has been developed from the literature examined. The perceived impacts of freedom camping are derived from the tourism impacts recorded in prior impact studies. These impacts encompass different social, environmental, and economic aspects. Additionally, literature specifically focused on freedom camping has identified potential impacts associated directly with this practice and these have been incorporated into the framework. It is expected 
the host community's perceptions of these impacts are influenced by their employment relationship with tourism and the underlying concept of SET. These perceived impacts help to form an understanding of the host community's overall support for the activity of freedom camping in a destination.

Figure 2.6: Perceived Impacts of Freedom Camping Conceptual Model

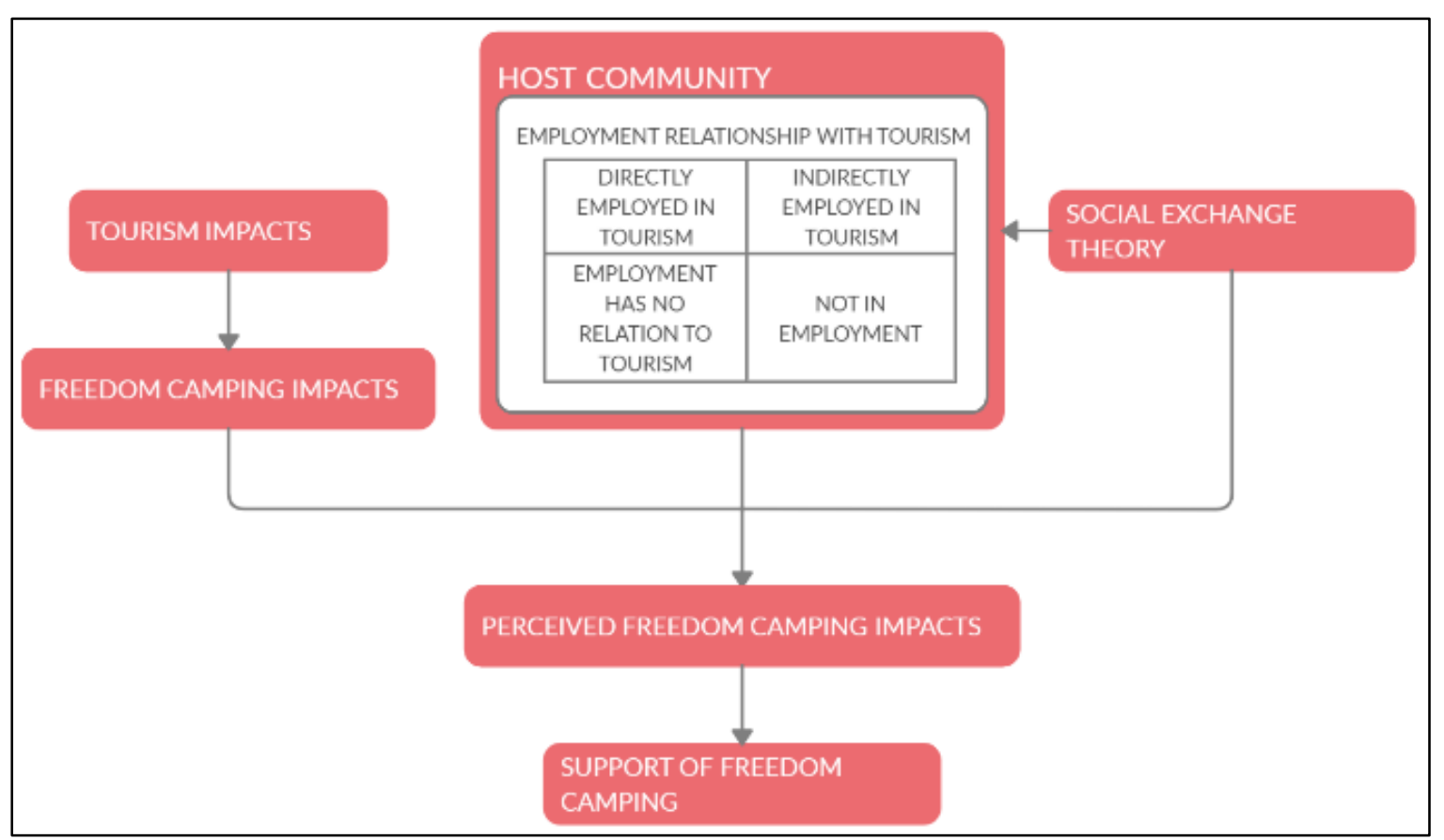

\subsection{Summary}

The literature review sought to develop a fundamental understanding of existing work in the research area addressed in this study. It provided insights into the current status of freedom camping in New Zealand and the Taupō District, along with freedom camping impacts, tourism impacts, social exchange theory, and the importance of the host community. Ultimately, the literature review led to the development of a conceptual framework detailing the core concepts of the thesis topic. 


\section{CHAPTER THREE: RESEARCH METHODOLOGY}

\subsection{Introduction}

This chapter details the research methodology that was used to explore the host community's perceptions of freedom camping impacts in the context of the Taupō District (see Figure 3.1). Firstly, the research paradigm, which is the philosophical underpinnings of the research, is outlined. Next, the research approach and data analysis are detailed. Following on from this, conditions around reliability, validity, and generalisability are discussed. Finally, the limitations that emerge from the methodology are noted. Figure 3.1, below, delineates how this research was conducted and the ensuing data collection process.

Figure 3.1: Research Outline

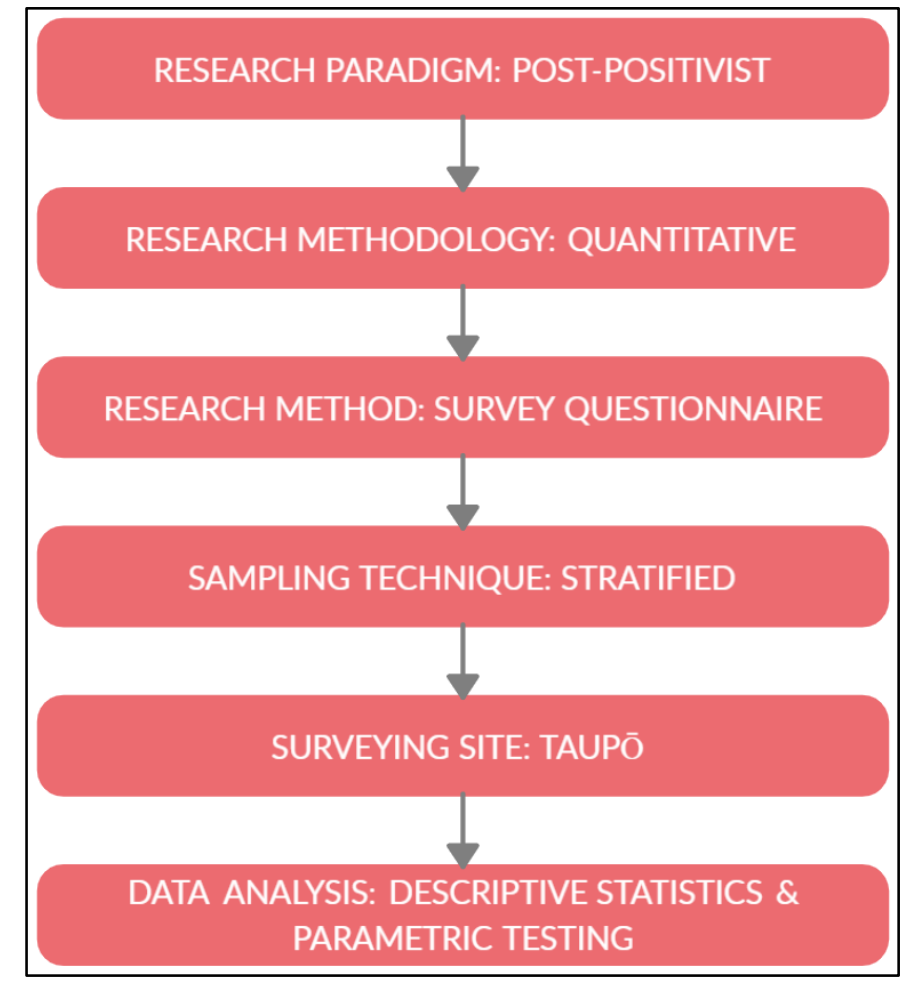

\subsection{Research Paradigm}

The term 'paradigm' is used to refer to the philosophical assumptions or the basic set of beliefs that guide the actions and define the worldview of the researcher (Guba, 1990; Lincoln et al., 2011). The term was introduced by Thomas Kuhn (1970), to deliberate about the shared beliefs, generalisations, and values of a community of specialists regarding the nature of reality and knowledge (Kaushik \& Walsh, 2019, p.255). According to Creswell (2014, p.35) paradigms arise based on discipline orientations, prior research experiences, and 
students' supervisors' dispositions. These factors will consequently determine which type of methodological approach a researcher will embrace in their research.

This research has adopted a post-positivist perspective. Post-positivist research is also referred to as positivist/post-positivist research, empirical science, and post-positivism (Creswell, 2014, p.36). According to Jennings (2007, p.14), post-positivist research is primarily predicated on quantitative methods and deductive reasoning and it recognises that when studying the behaviour and actions of humans, we cannot be positive about claims of knowledge. Knowledge is assumed as being conjectural, and the absolute truth can never be found, as evidence from research is always flawed. Post-positivist research seeks to develop relevant and accurate statements that clarify the situation being examined or that describe relationships of interest (Creswell, 2014; Phillips \& Burbules, 2000). In post-positivist research, a researcher is no longer seen to be independent from the object of study and their bias in the research design is acknowledged (Jennings, 2007). Nevertheless, objectivity is an essential aspect of the post-positivist research and remains an ideal to be achieved (Creswell, 2014; Kaushik \& Walsh, 2019).

A post-positivist perspective was chosen for this research as the research is looking at perceptions and is therefore not completely objective and a purely positivist paradigm does not fit. Further, this paradigm was adopted as it recognises that multiple realities exist, meaning what might be 'truth' for one person or cultural group may not be 'truth' for another (O'Leary, 2004). It also recognises individuals' perspectives are impacted by their inherent biases and different experiences. Thus, the research can explore the realities of those being surveyed but does not claim to present one overarching truth. The post-positivist approach is reflected in the quantitative nature of the research and the aim of theory falsification rather than verification regarding social exchange theory's (SET) influence on the host community perceptions of freedom camping impacts.

\subsection{Research Approach}

Research designs are recognised as strategies of inquiry with quantitative, qualitative, and mixed method approaches that provide direction for the research procedures (Creswell, 2014; Denzin \& Lincoln, 2011). To address the research objectives, a quantitative approach has been used in this study. Quantitative approaches to research are generally backed by postpositivist philosophical assumptions and employ either non-experimental designs, such as surveys, or experimental designs as the strategy of inquiry (Creswell, 2014). Non-experimental 
quantitative research generally uses item based closed-ended questions and employs statistical procedures to analyse the data gathered (Creswell, 2014). This research employed a nonexperimental survey design, which provides a numerical description of perceptions and trends of a sample population.

\subsubsection{Questionnaire}

A structured self-complete questionnaire was chosen as the instrument for data collection. The questionnaire contained a total of 17 questions across four sections. Five-point Likert scales were employed throughout the questionnaire to examine the host community's perceptions of freedom camping impacts, as well as their support for the freedom camping industry. Likert scales are a type of instrument frequently used in research and can be defined as 'a psychometric scale that has multiple categories from which respondents choose to indicate their opinions, attitudes, or feelings about a particular issue' (Nemoto \& Beglar, 2014, p.2). Additionally, an open-ended question was included at the end of the survey to enable respondents to further express their opinions and add depth to the findings. A pilot survey was conducted prior to the data collection to pre-test the questionnaire for the revision of any issues that arose, along with testing the recruitment method employed. A pilot study is a practice which ensures the reliability and validity of questions (Dann, Nash \& Pearce, 1988). Thus, it is important that a pilot study is completed prior to the beginning of the official surveying. The

pilot survey was completed by ten respondents and verbal feedback was received at the end of the questionnaire's completion to make improvements. Those who participated in the pilot were excluded in the main study. Minor adjustments to the questionnaire were made to refine the clarity and flow of the questions, thus ensuring the survey was able to be completed unassisted. It was decided that printed surveys would have a higher level of engagement than online surveys and thus paper surveys with clipboards and pens attached were used.

\subsubsection{Research Design}

The questionnaire consisted of four sections (see Appendix B). Section 1 contained questions about the respondents' connection to the Taupō District and their relationship with freedom camping. It contained questions about the respondents' history in the district (where they live and their length of residency). Further, it enquired about their employment relationship with the tourism industry (what their employment relationship is and, if applicable, what sector they belong to). Respondents self-declared which group they belonged to: those directly employed in tourism, those indirectly employed in tourism, those whose employment has no relation to tourism, and those not in employment. Section 2 addressed the perceived 
impacts associated with freedom camping. To assess this, construct measures were collated from previous validated scales used in tourism literature, that were adapted to fit the context of freedom camping research. Specifically, it was based on the research works of Andereck et al. (2005), Brunt and Courtney (1999), Dogan (1989), Haralambopoulos and Pizam (1996), Johnson et al. (1994), Lankford (1994), Liu and Var (1986), McCool and Martin (1994), Okech (2010), and Tosun (2002), which were discussed throughout Section 2.5. These were combined with the unevaluated freedom camping impacts identified in the literature from Collins et al. (2018) and Hardy et al. (2013) and, to fit this study, were subsequently developed into three impact tables; social impacts, environmental impacts, and economic impacts. As this research is exploratory in nature it adopted these three impact groups, however, it is important to recognise that the items used may logically fit in more than one of the three groups. The social impacts table contained 9 items, the environmental table contained 11 items, and the economic table contained 7 items. At the bottom of each table a space was left for the respondent to contribute any additional impact items that they saw as important. A five-point Likert scale, 1 being Disagree and 5 being Agree, with a midpoint of 3 being Neither Agree nor Disagree, was employed for respondents to rank their responses to statements regarding the impacts of freedom camping. Section 3 focused on the assessment of the respondents' support of freedom camping. Prior literature was used to develop statements pertaining to the support of freedom camping, and these were also ranked using a five-point Likert scale. Additionally, this section contained questions regarding how freedom camping has impacted on Taupō's destination image using a five-point Likert scale, 1 being Worsened and 5 being Improved, with a midpoint of 3 being Not Made a Difference. Another question inquired about the respondents preferred number of freedom campers and tourists using a five-point Likert scale, 1 being [numbers of freedom campers/tourists] Should Decrease and 5 being [numbers of freedom campers/tourists] Should Increase, with a midpoint of 3 being [numbers of freedom campers/tourists] Is Appropriate. Finally, this section contained an open-ended question where respondents were asked to provide their overall thoughts about freedom camping in New Zealand. This question was included to allow respondents to elaborate on their answers and add detail and depth to the analysis. Lastly, section 4 was included to obtain the respondents' personal demographic data, specifically gender, age, and ethnicity. This information was obtained to compare the research sample to the general population of the Taupō District, and therefore understand the generalisability of the results. 


\subsubsection{Sampling}

The sample design of a study should consider the research aims and resources that are available. Sampling is required to maximise the reliability and validity of the data collected (Patton, 1990). In this study, an adapted version of stratified sampling focused on employment strata for Taupō District residents was employed. Stratified sampling is a type of sampling where the population is divided into exclusive groups, known as strata, along a particular dimension such as age or gender, or in this case employment. A sample which involves population members from within each relevant stratum were collected (Lemm, 2012). This approach was implemented through random sampling at seven predetermined survey sites in high-flow public areas to ensure all strata are represented (Lemm, 2012). The sites were spread across Taupō Town and diversified based on the need to recruit different population groups to capture different strata (see Appendix C). When this approach did not yield sufficient responses for some strata, the approach was adapted by randomly approaching employees in tourism related businesses to invite them to participate in the survey.

To be eligible for this study, it was required that respondents be a minimum of 18 years old and permanent residents of the Taupō District. These criteria were established as the research is focused on the perceptions of the host community and is specifically addressing freedom camping in the Taupō District. The characteristics, experiences and knowledge of these respondents match the research objectives. Potential respondents were approached as they passed the chosen data collection locations and asked screening questions to check for eligibility.

\subsubsection{Data Collection}

Data collection commenced in late November and ended in early December 2019, spanning a total of 18 days. This was done to complete the data collection prior to the commencement of the Christmas holidays, as during this time there would be the possibility of locals leaving the district and an increase in tourists to the area. A variety of locations were used to approach respondents to achieve a representative sample across the strata. Data location points were mapped prior to travelling and were revised once in Taupō (see Appendix C). Locations chosen were determined as being high-flow public areas that were likely to enable interactions with locals from the different towns in the district and all four strata (see Figure 3.2 below). The locations had seating available nearby so that respondents could take the survey away to complete in a manner which was convenient for them. A sampling matrix was developed as a key tool to reduce sampling bias (see Appendix D). Countdown and Pak'n'Save 
supermarkets were initially chosen as they were recognised as likely places for locals to visit. Both supermarkets responded positively when contacted about the surveying and granted permission to survey at their stores. However, once the data collection process began these destinations proved to be difficult to recruit respondents at due to a variety of unanticipated challenges. The approved surveying spots at both supermarkets were awkwardly placed between the entrance and exit and lacked both shelter and adequate seating. Due to the exposure to the elements and limited time once shoppers had exited the stores with their groceries, these collection locations were sparsely used. Bunnings Warehouse was another survey location point that was revised prior to the commencement of the data collection as the company did not grant permission for surveying on their premises. The survey location point of the Salvation Army - Op Shop was added on the first day of data collection, as it was used for the pilot survey and proved to attract people who had little time pressure and could afford to stop, as well as providing various seating options. While the study is based on the Taupo District, the surveying was largely conducted in Taupō Town as the focal point of the district, and the town in the region with the highest population and greatest population density.

Figure 3.2: Data Collection Locations

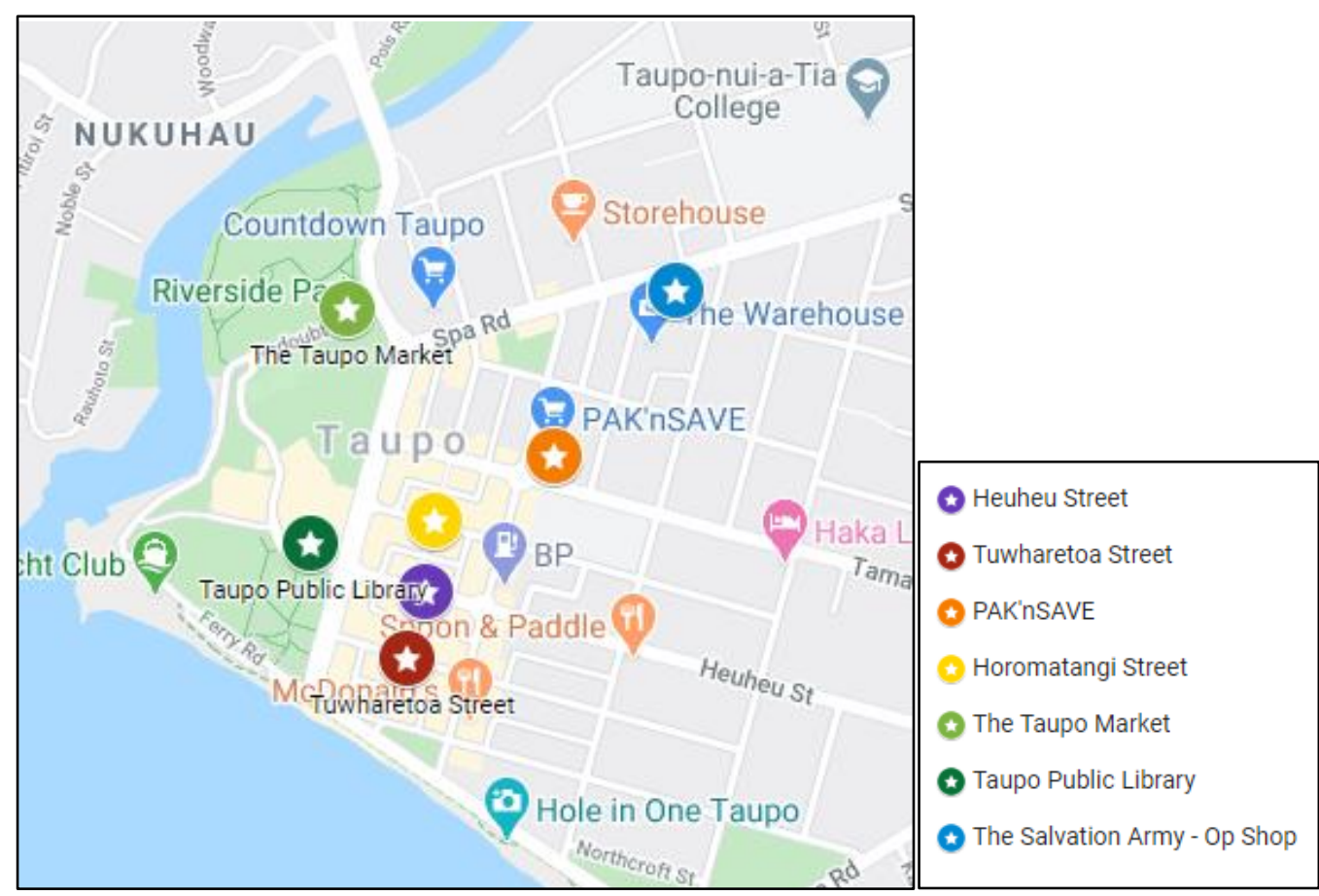

After a review of the 76 surveys obtained in the first week of data collection, it was apparent that there was a lack of representation from workers directly and indirectly employed in tourism. Thus, it was decided that in addition to the public data collection locations, several local tourism-related businesses would be directly approached, and their staff would be invited 
to participate in the survey. Allocated time to visit businesses was incorporated into the sampling matrix. Businesses that were approached were a variety of accommodation, retail, and attractions and activities. The locations of the businesses varied from in Taupō Town to other towns in the popular tourist locations. The surveys were distributed to the staff members and a collection time was organised, ranging from one to four days depending on what the business decided. Tourism related businesses were approached as they had low representation in the random sampling and therefore the adapted sampling approach ensured that all strata were represented. Furthermore, the coverage of different businesses provided for a representative sample of employment, age, and gender.

As an incentive to engage in the research, respondents who completed the survey went into the draw to win one of two $\$ 50$ supermarket vouchers. The prize forms were detachable from the survey questionnaire and collected in a separate box to ensure anonymity.

\subsection{Ethical Considerations}

Ethical considerations are an essential part of conducting responsible research. Research in the social sciences mostly involves dealing with people, organisations, and groups in a situation where they may have to disclose personal information and due to this, ethical issues may arise (Bouma \& Ling, 2004). Therefore, consent is required prior to conducting research. This research was conducted following the requirements of the Human Ethics Committee of Victoria University of Wellington (HEC-VUW). HEC-VUW approval, number: 0000028023, was obtained before the process of data collection commenced. The Treaty of Waitangi was considered in this research and the Tuwharetoa Māori Trust Board was emailed about meeting to discuss the research; however, no reply was received. Taupō District Council was also contacted to inform them of the research.

Data collection was undertaken through a self-complete survey. The random sampling data collection points were spread across Taupō Town and, depending on the location, the relevant business owners were contacted to get their permission to survey outside their premises. None of the questions included in the survey required for the respondent to share sensitive information. Additionally, this study only used respondents aged 18 years or older to ensure their ability to give informed consent. An information sheet was used to inform respondents about the research, detailing that the questionnaire was both voluntary and confidential. Furthermore, it stated that all data collected would be reported in aggregate form to ensure confidentiality. Finally, respondents were informed that access to the research data is 
restricted to the researcher and their supervisor, and would be destroyed once the research had concluded.

\subsection{Data Analysis}

Data analysis is used to understand the data that has been collected. Findings from the data are able be used to accomplish the research objectives. This section details the statistical approaches used in the research and how they correspond with the research objectives (see Figure 3.3). This study employed IMB's Statistical Package for the Social Sciences (SPSS) v.26.0 to analyse and interpret the data. Cross-tabulations were conducted to determine the characteristics of the sample population and compare these against census data. Descriptive statistics were used to measure the perceived impacts and support of freedom camping. To test for differences in perception between the employment groups a principal component analysis (PCA) was run to identify components for testing. Subsequently, one-way analysis of variance (ANOVA) tests were run on these identified components, and the statistical significance was analysed. To analyse the open-ended survey question, a thematic analysis was applied.

\subsection{Analytical Framework}

As proposed by Pearce (2012), analytical frameworks help researchers to structure their data analysis and to clearly communicate their findings. The analytical framework depicted in Figure 3.3 below, shows the proposed analytical tests and how they correspond with the research objectives outlined in Section 1.5.

Figure 3.3: Analytical Framework

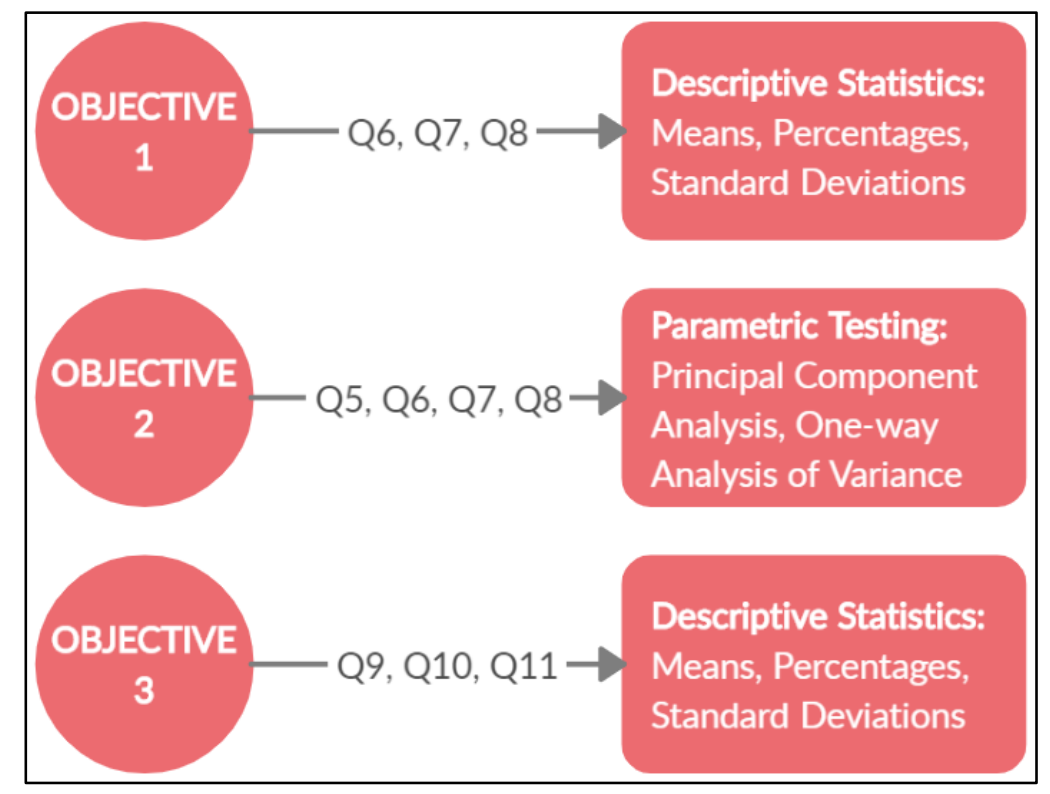




\subsection{Reliability, Validity \& Generalisability}

This section details the reliability, validity, and generalisability, which are recognised as indicators of good research in quantitative studies.

\subsubsection{Reliability}

Carrig and Hoyle (2011, p.127) define reliability as 'the consistency of measure instrument scores across replications of the measure procedure'. O'Leary (2004) elaborates on this stating that reliability is concerned with the internal consistency of the study and whether under repeated trials the data or results collected, measured, or generated will be the same. Reliability assumes that the results of a survey are not dependant on external factors such as who administered the questionnaire. One way to test for reliability is to issue the questionnaire to respondents more than once, however, this was not possible in this study as the research was anonymous. Another way to test reliability is to use multiple questions to measure constructs. This was done for the construct of the perceived impacts of freedom camping where components were extracted from a PCA. Cronbach's $\alpha$ method was used to test for internal consistency. Cronbach (1951), suggested that a high value of alpha is considered 'desirable' when an instrument is being used to assign a score to an individual. However, there is debate over what values are acceptable in research. According to Straub et al. (2004), values of $\alpha=0.70$ and above are acceptable for confirmatory research and values of $\alpha=0.60$ or greater are acceptable for exploratory research. As this research was exploratory in nature, a Cronbach's $\alpha$ of 0.60 or greater was considered acceptable.

\subsubsection{Validity}

Messick (1989, p.13) describes validity as a judgement of the degree to which empirical evidence and theoretical rationales support the appropriateness and fairness of actions and assumptions based on test scores or alternative modes of assessment. Thus, validity is concerned with whether the conclusions made from the research are 'correct' and if the methods, approaches, and techniques that have been employed are relevant to what is being explored (O'Leary, 2004). Good validity signifies that the method used warrants the conclusions that are made in the study. There are three types of validity that are outlined in this section: internal validity, construct validity, and external validity.

Internal validity describes systematic factors of bias and ensures that alternative explanations for findings can be eliminated (Easterby-Smith et al., 2008). In this study, internal 
validity is managed by a comprehensive literature review. The items included in the survey questionnaire were extracted and compiled from the literature examined. Additionally, a pilot study was undertaken prior to the data collection to test the questions and feedback was received from the pilot study's respondents. These measures ensured that the questionnaire could be accurately understood by respondents and was applicable to the situation being researched.

Construct validity is focused on how the essence of a construct is captured through the instrument items used (Straub et al., 2004). This survey included the use of different items measuring the construct of freedom camping impacts. These items were extracted from previously validated items from literature to create a survey. Additionally, a PCA was conducted to group the items together for further analysis.

External validity relates to the generalisability of the findings (Easterby-Smith et al., 2008) and is examined in the following section.

\subsubsection{Generalisability}

The generalisability of the research looks at whether the findings collected, and conclusions made from a sample, group, or setting are directly applicable to a larger population, to another group, or a different setting (O'Leary, 2004). It is recognised that for research findings to be generalisable, the samples taken must be of a sufficient size (Easterby-Smith et al., 2008). In this study, a usable sample size of 182 was obtained. In an attempted to reach respondents with varying demographics, two channels were used, street surveying and directly approaching tourism-related businesses. This research aims to generalise finding only across the Taupō District, and not across all of New Zealand, as other districts have differing relationships with freedom camping depending on their geographical features and population density. An overview of the sample characteristics and a comparison of these with New Zealand's latest census data on the Taupō District is included in Section 4.3.1.

\subsection{Limitations}

The first limitation of the data collection is the possibility for voluntary bias due to the data collection method. The phenomenon of voluntary bias suggests that only those with strong opinions on what is being studied are likely to respond (Kýlýnç \& Fırat, 2017).

The second limitation is that the overall sample size was small compared to the district's population. The participation rate was lower than anticipated, but the timeframe and monetary 
cost of undertaking data collection did not allow the researcher to conduct more extensive surveying.

A third limitation was the sample sizes of the four different employment groups. Despite initially struggling to reach those directly employed in tourism, this ended up being the largest group, with 72 respondents. Conversely, the other three groups had fewer respondents and therefore less representation.

Another limitation of representation arose due to the difficulty of engaging with different demographic groups, specifically individuals accompanied by children. While families were still approached and given the option to return the questionnaire at a time convenient to them, there was a still a high rejection rate from them.

The fifth limitation arises from a general weakness associated with questionnaire survey instruments. The survey instrument was self-administered and therefore questions have the potential to be misunderstood by respondents. To reduce this risk of ambiguity within the questionnaire, a pilot study was run with discussions around feedback at the end. Additionally, during the data collection the researcher was present to answer any respondent questions.

Finally, there were limitations regarding the geographical location of the surveying. The locations originally chosen for the data collection were all based in Taupō Town, which was chosen as the focal town due to the population size and density compared to the rest of the district, as well as due to resource constraints. This meant that respondents living in other towns throughout the district did not have equal opportunity to participate in the survey, though it is noted that respondents from other towns were also present at these sites, and businesses outside of the town were also approached. Due to this, the majority of respondents were from Taupo Town, and the results may not generalise as strongly to the whole of the Taupo District.

\subsection{Summary}

This chapter has sought to explain the philosophical assumptions of the chosen methodology, the research approach, and the data analysis process. Lastly, reliability, validity, and generalisability were discussed, along with the limitations of the data collection. 


\section{CHAPTER FOUR: FINDINGS}

\subsection{Introduction}

Chapter Four is guided by the analytical framework in Section 3.6 and the data analysis and results. Firstly, the response analysis is described, then the characteristics of the sample population are presented and compared with census data, and the characteristics of the four employment groups are outlined. Following this, the perceived impacts of freedom camping are analysed, and the overall support for freedom camping is examined. Next, comparisons are made for the differences in perceptions of freedom camping impacts across the different employment groups. Finally, the opened-ended question is examined.

\subsection{Response Analysis}

A total of 220 surveys were distributed to Taupō District residents during data collection, and a total of 182 valid respondent surveys were gathered as a result, providing a response rate of $82.7 \%$. As outlined in Section 3.3.3, eligible respondents for this survey were permanent residents of the Taupō District, 18 years of age and above. Overall, 111 respondents came from the designated street-based data collection points in Taupō Town and 71 respondents came from directly approaching tourism-related businesses operating across the Taupō District.

\subsection{Sample Characteristics}

\subsubsection{Sample Characteristics Overview}

Firstly, the characteristics of gender, age, and ethnicity of the sample population are examined (see Table 4.1 below). Among the 182 respondents, 39.0\% (71) identified themselves as being male, 59.3\% (108) as female, and 1.6\% (3) as gender diverse. The distribution of age shows that the respondents spanned across all of the defined age groups. Respondents in the age group of 18-24 years were the largest group at 22.0\% (40), however, all age groups were relatively close in size. The ethnicity results showed that most respondents consider themselves as being NZ European (75.3\%), followed by NZ Māori (22.5\%), Other Ethnicity (3.8\%), Asian (2.7\%) and Pacific Islander (1.6\%). Other ethnicities recorded included British, Indian, and South African. It is important to note that while the questionnaire asked respondents to select the ethnicity that they identify with the most, a significant number of respondents ticked more than one ethnicity. Consequently, where people have recorded more than one ethnicity, they have been counted in each of the groups identified and thus the total is over $100 \%$. 
Table 4.1: Sample Demographics

\begin{tabular}{|c|c|c|}
\hline Gender & Frequency & Percentage \\
\hline Male & 71 & 39.0 \\
\hline Female & 108 & 59.3 \\
\hline Gender Diverse & 3 & 1.6 \\
\hline Total & 182 & 100.0 \\
\hline Age & Frequency & Percentage \\
\hline $18-24$ years & 40 & 22.0 \\
\hline $25-34$ years & 23 & 12.6 \\
\hline $35-44$ years & 25 & 13.7 \\
\hline $45-54$ years & 38 & 20.9 \\
\hline $55-64$ years & 24 & 13.2 \\
\hline$\geq 65$ years & 32 & 17.6 \\
\hline Total & 182 & 100.0 \\
\hline Ethnicity $^{\mathbf{a}}$ & Frequency & Percentage \\
\hline NZ European & 137 & 75.3 \\
\hline NZ Māori & 41 & 22.5 \\
\hline Pacific Islander & 3 & 1.6 \\
\hline Asian & 5 & 2.7 \\
\hline Other Ethnicity & 7 & 3.8 \\
\hline Total & 182 & 105.9 \\
\hline
\end{tabular}

a Where people have reported more than one ethnic group they have been counted in each applicable group, due to this the total percentage is over $100 \%$

In this section, the sample populations' length of residency and residential location in the Taupō District is explored (see Table 4.2 below). The survey showed that nearly half the respondents $(49.5 \%)$ have been living in the district for over a decade, with over a quarter (28.6\%) having lived there for 21 years or longer. For the distribution of residents throughout the district, $76.9 \%$ of respondents (140) live in the suburbs of Taupo Town, including Acacia Bay, Boat Harbour, Cherry Islands, Five Mile Bay, Hilltop, Industrial Area, Nukunau, Rainbow Point, Richmond Heights, Tauhara, Taupō CBD, Waipahihi, and Wharewaka. This shows a wide geographical spread of respondents from within Taupō Town. The town of Kinloch had the next highest number of respondents at $7.1 \%$ (13), followed by Waitahanui at $3.8 \%$ (7), Wairakei at 2.2\% (4), Mangakino at $1.6 \%$ (3) and Turangi at 1.1\% (2). Furthermore, $7.1 \%$ of respondents (13) recorded themselves as living in other locations throughout the district; Bonshaw Park, Broadlands Forest, Oruanui, Poihipi Road, Pukawa, Rangatira Park, Rangitaiki, and Reid's Farm (see Figure 4.1 below). 
Table 4.2: Residency in Taupō District

\begin{tabular}{rrrr}
\hline Length of Residency in Taupō District & Frequency & Percentage \\
\hline & $<1$ year & 16 & 8.8 \\
$1-5$ years & 47 & 25.8 \\
$6-10$ years & 29 & 15.9 \\
$11-20$ years & 38 & 20.9 \\
& $\geq 21$ years & 52 & 28.6 \\
\hline Total & 182 & 100.0 \\
\hline Residential Location in Taupō District & & Frequency & Percentage \\
\hline Kinloch & 13 & 7.1 \\
Mangakino & 3 & 1.6 \\
Taupō Town & 140 & 76.9 \\
Turangi & 2 & 1.1 \\
Wairakei & 4 & 2.2 \\
Waitahanui & 7 & 3.8 \\
OTher & 13 & 7.1 \\
Total & 182 & 100.0 \\
\hline
\end{tabular}

Figure 4.1: Respondents' Residential Locations in Taupō District

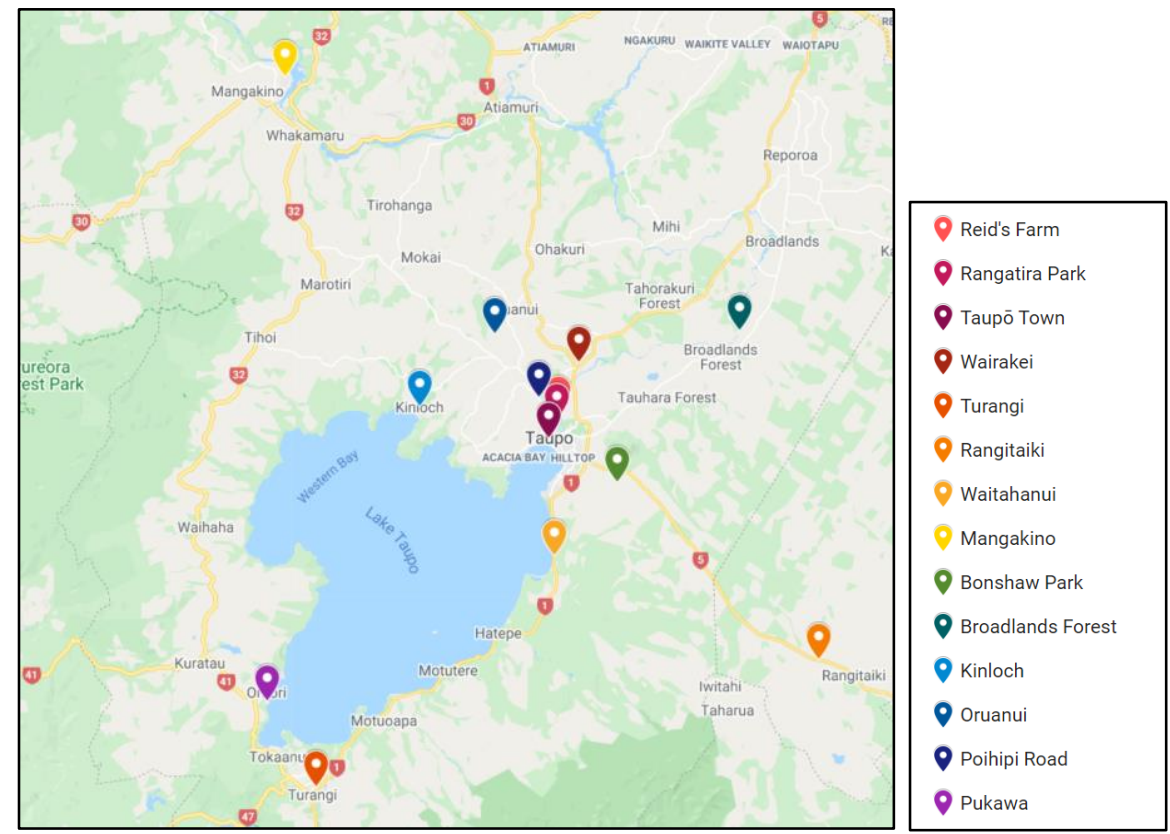

In this section, the demographic characteristics of gender, age, and ethnicity from the research sample are compared with the 2018 New Zealand Census data (see Table 4.3) (Stats NZ, 2018). The sample population consisted of approximately $0.5 \%$ of the total residents living in Taupō District. The gender distribution of the sample population differs from the Taupō District census data, with almost three fifths (59.3\%) of the sample being female and only 39\% being male. In contrast, the census data shows an almost even split between female $(50.2 \%)$ and male (49.8\%). However, it should be noted that the survey recorded residents' gender identity and therefore also included the category of gender diverse, which accounted for $1.6 \%$ of the sample population. When comparing the age groups between the census and the sample, 
it should be noted that the sample was restricted to respondents aged 18 years and over, whereas the census collects data from all ages. Despite this, most of the age groups were similar. There were two groups in the sample population with notably higher representation compared to the census data. The 18-24 years age group in the sample constitutes $22 \%$ of the sample population, which is over twice the size of the 15-24 years age group in the census (10.4\%). Additionally, the $45-54$ years age group made up $20.9 \%$ of the sample population and only $13.4 \%$ of the census population. The ethnic spread across the sample and the census are similar, with both populations predominately identifying as NZ European/European, at $75.3 \%$ and $76.4 \%$ respectively. The census data has a higher percentage of Māori, at 29.9\%, with the sample recording $22.5 \%$ NZ Māori respondents. The sample population also had lower percentages for both Pacific Islander/Pacific Peoples and Asian ethnicities, and a higher percentage of Other Ethnicity.

Table 4.3: Demographic Comparison Between Sample and Taupō District Census Data

\begin{tabular}{|c|c|c|c|}
\hline \multicolumn{4}{|c|}{ Gender } \\
\hline \multicolumn{2}{|c|}{ Research Sample } & \multicolumn{2}{|c|}{ Taupō District Census Data New Zealand 2018} \\
\hline \multirow[t]{2}{*}{ Gender } & $(\%)$ & Sex & $(\%)$ \\
\hline & $(39.0)$ & Male & $(49.8)$ \\
\hline Female & $(59.3)$ & Female & $(50.2)$ \\
\hline Gender Diverse & $(1.6)$ & Total & $(100.0)$ \\
\hline Total & $(100.0)$ & & \\
\hline \multicolumn{4}{|c|}{ Age } \\
\hline \multicolumn{2}{|c|}{ Research Sample } & \multicolumn{2}{|c|}{ Taupō District Census Data New Zealand 2018} \\
\hline Age & $(\%)$ & Age $^{\mathbf{a}}$ & $(\%)$ \\
\hline 18-24 years & $(22.0)$ & $\leq 14$ years & $(20.6)$ \\
\hline 25-34 years & $(12.6)$ & $15-24$ years & $(10.4)$ \\
\hline $35-44$ years & $(13.7)$ & $25-34$ years & $(11.8)$ \\
\hline $45-54$ years & $(20.9)$ & $35-44$ years & $(11.7)$ \\
\hline $55-64$ years & $(13.2)$ & $45-54$ years & $(13.4)$ \\
\hline$\geq 65$ years & $(17.6)$ & $55-64$ years & $(13.1)$ \\
\hline \multirow[t]{2}{*}{ Total } & $(100.0)$ & $\geq 65$ years & $(19.0)$ \\
\hline & & Total & $(100.0)$ \\
\hline \multicolumn{4}{|c|}{ Ethnicity } \\
\hline \multicolumn{2}{|c|}{ Research Sample } & \multicolumn{2}{|c|}{ Taupō District Census Data New Zealand 2018} \\
\hline Ethnicity $^{b}$ & $(\%)$ & Ethnicity $^{b}$ & $(\%)$ \\
\hline NZ European & $(75.3)$ & European & $(76.4)$ \\
\hline NZ Māori & $(22.5)$ & Māori & (29.9) \\
\hline Pacific Islander & $(1.6)$ & Pacific peoples & $(3.2)$ \\
\hline Asian & $(2.7)$ & Asian & $(4.9)$ \\
\hline Other Ethnicity & $(3.8)$ & Other Ethnicity & (1.7) \\
\hline Total & (105.9) & Total & $(116.1)$ \\
\hline
\end{tabular}


This section details the sample population's employment relationship with tourism (see Table 4.4 below). Results show that over one third of respondents $39.6 \%$ (72) are directly employed in the tourism industry, a further $18.1 \%$ (33) of respondents are indirectly employed in tourism, 24.7\% (45) of respondents are employed in jobs that have no relation to tourism, and lastly $17.6 \%$ (32) of respondents reported not being in employment. Of those directly employed in the tourism industry, the accommodation sector accounted for $30.6 \%$, attractions and activities made up 50\%, and transport made up 1.4\%. Those working across a combination of the sectors listed accounted for $6.9 \%$ and lastly, those working in other jobs within the tourism industry not listed in survey accounted for $11.1 \%$. The other jobs recorded included working as a DoC officer, at an i-Site, as a travel agent, or in tourism-based retail such as a souvenir store.

Table 4.4: Employment Relationship with Tourism

\begin{tabular}{|c|c|c|}
\hline Employment Relationship with Tourism & Frequency & Percentage \\
\hline Directly Employed & 72 & 39.6 \\
\hline Indirectly Employed & 33 & 18.1 \\
\hline Employment No Relation & 45 & 24.7 \\
\hline Not in Employment & 32 & 17.6 \\
\hline Total & 182 & 100.0 \\
\hline Directly Employed in the Tourism Industry & Frequency & Percentage \\
\hline Accommodation & 22 & 30.6 \\
\hline Attractions and Activities & 36 & 50.0 \\
\hline Transport & 1 & 1.4 \\
\hline Other & 8 & 11.1 \\
\hline Combination & 5 & 6.9 \\
\hline Total & 72 & 100.00 \\
\hline
\end{tabular}

This section examines the sample population's engagement in freedom camping as a way of indicating their own personal experience with the activity (see Table 4.5 below). Just over a quarter of respondents $25.3 \%$ (46) recorded having freedom camped in the last 10 years, all of whom had freedom camped in New Zealand. Of this, 82.6\% (38) have freedom camped solely in New Zealand and $17.4 \%$ (8) have also freedom camped in overseas locations. The overseas locations recorded in the survey included Australia, France, Portugal, and Spain.

Table 4.5: Experience with Freedom Camping

\begin{tabular}{|c|c|c|}
\hline Freedom Camping in the Last 10 Years & Frequency & Percentage \\
\hline No & 136 & 74.7 \\
\hline Yes & 46 & 25.3 \\
\hline Total & 182 & 100.0 \\
\hline Freedom Camping Locations & Frequency & Percentage \\
\hline New Zealand & 38 & 82.6 \\
\hline New Zealand \& Overseas & 8 & 17.4 \\
\hline Total & 46 & 100.00 \\
\hline
\end{tabular}




\subsubsection{Characteristic Analysis of Groups}

To compare perceptions within the host community later in the chapter, the sample population is divided into four groups based on their employment relationship with tourism. As discussed in Section 3.3.2, the four groups were self-declared in the survey and consist of those directly employed in tourism, those indirectly employed in tourism, those whose employment has no relation to tourism, and those not in employment. In Table 4.6, below, a summary of the characteristics of the four different employment groups is presented. The table displays both the frequency $(n)$ and percentage (\%) across each of the categories.

Table 4.6: Characteristic Analysis of Groups

\begin{tabular}{|c|c|c|c|c|c|c|c|c|}
\hline & \multicolumn{2}{|c|}{$\begin{array}{c}\text { Directly } \\
\text { Employed }\end{array}$} & \multicolumn{2}{|c|}{$\begin{array}{l}\text { Indirectly } \\
\text { Employed }\end{array}$} & \multicolumn{2}{|c|}{$\begin{array}{c}\text { Employment } \\
\text { No Relation }\end{array}$} & \multicolumn{2}{|c|}{$\begin{array}{c}\text { Not in } \\
\text { Employment }\end{array}$} \\
\hline & $\mathrm{n}=72$ & $(\%)$ & $\mathbf{n}=\mathbf{3 3}$ & $(\%)$ & $\mathrm{n}=\mathbf{4 5}$ & $(\%)$ & $\mathbf{n}=\mathbf{3 2}$ & $(\%)$ \\
\hline \multicolumn{9}{|c|}{ Residential Location } \\
\hline Kinloch & 5 & $(6.9)$ & 4 & $(12.1)$ & 3 & $(6.7)$ & 1 & (3.1) \\
\hline Mangakino & 2 & $(2.8)$ & 0 & (0) & 1 & $(2.2)$ & 0 & (0) \\
\hline Taupō Town & 52 & $(72.2)$ & 25 & $(75.7)$ & 37 & $(82.2)$ & 26 & $(81.2)$ \\
\hline Turangi & 2 & $(2.8)$ & 0 & $(0)$ & 0 & (0) & 0 & $(0)$ \\
\hline Wairakei & 4 & $(5.6)$ & 0 & (0) & 0 & (0) & 0 & (0) \\
\hline Waitahanui & 2 & $(2.8)$ & 2 & (6.1) & 0 & (0) & 3 & (9.4) \\
\hline Other & 5 & (6.9) & 2 & (6.1) & 4 & $(8.9)$ & 2 & (6.3) \\
\hline \multicolumn{9}{|c|}{ Length of Residency } \\
\hline$<1$ year & 3 & $(4.2)$ & 2 & $(6.1)$ & 5 & $(11.1)$ & 6 & (18.8) \\
\hline $1-5$ years & 22 & $(30.6)$ & 8 & $(24.2)$ & 9 & $(20.0)$ & 8 & $(25.0)$ \\
\hline $6-10$ years & 9 & $(12.5)$ & 7 & $(21.2)$ & 10 & $(22.2)$ & 3 & $(9.4)$ \\
\hline $11-20$ years & 14 & (19.4) & 5 & $(15.2)$ & 13 & $(28.9)$ & 6 & (18.8) \\
\hline$\geq 21$ years & 24 & $(33.3)$ & 11 & $(33.3)$ & 8 & $(17.8)$ & 9 & $(28.1)$ \\
\hline \multicolumn{9}{|l|}{ Age } \\
\hline $18-24$ & 25 & $(34.7)$ & 10 & $(30.3)$ & 2 & $(4.4)$ & 3 & (9.4) \\
\hline $25-34$ & 14 & (19.4) & 6 & $(18.2)$ & 2 & $(4.4)$ & 1 & (3.1) \\
\hline $35-44$ & 9 & $(12.5)$ & 4 & (12.1) & 10 & $(22.2)$ & 2 & $(6.3)$ \\
\hline $45-54$ & 16 & $(22.2)$ & 5 & (15.2) & 13 & (28.9) & 4 & (12.5) \\
\hline $55-64$ & 4 & $(5.6)$ & 6 & $(18.2)$ & 10 & $(22.2)$ & 4 & (12.5) \\
\hline$\geq 65$ & 4 & $(5.6)$ & 2 & $(6.1)$ & 8 & $(17.8)$ & 18 & $(56.2)$ \\
\hline \multicolumn{9}{|l|}{ Gender } \\
\hline Male & 21 & $(29.2)$ & 17 & $(51.5)$ & 19 & $(42.2)$ & 14 & $(43.8)$ \\
\hline Female & 49 & $(68.0)$ & 15 & $(45.5)$ & 26 & $(57.8)$ & 18 & $(56.2)$ \\
\hline Gender Diverse & 2 & $(2.8)$ & 1 & $(3.0)$ & 0 & $(0)$ & 0 & $(0)$ \\
\hline \multicolumn{9}{|l|}{ Ethnicity ${ }^{a}$} \\
\hline NZ European & 52 & $(72.2)$ & 23 & $(69.7)$ & 35 & $(77.8)$ & 27 & $(84.4)$ \\
\hline NZ Māori & 17 & $(23.6)$ & 9 & $(27.3)$ & 8 & $(17.8)$ & 7 & (21.9) \\
\hline Pacific Islander & 2 & $(2.8)$ & 0 & $(0)$ & 1 & $(2.2)$ & 0 & (0) \\
\hline Asian & 2 & $(2.8)$ & 1 & $(3.0)$ & 2 & (4.4) & 0 & (0) \\
\hline Other Ethnicity & 4 & $(5.6)$ & 1 & $(3.0)$ & 1 & $(2.2)$ & 1 & (3.1) \\
\hline
\end{tabular}

a Where people have reported more than one ethnic group they have been counted in each applicable group, due to this the total percentage is over $100 \%$

Those directly employed in the tourism, is the biggest group $(n=72)$ and has the widest geographical spread throughout the district, with at least two respondents coming from each of 
the seven recorded locations. This group also has the equal highest percentage of people having lived in the district for 21 years, at $33.3 \%$. Approximately one third of the group (34.7\%) is 18 24 years old. This group also has the most significant gender imbalance, with $68.0 \%$ female respondents. NZ European is noticeably the most common ethnicity at $72.2 \%$, followed by $N Z$ Māori at $23.6 \%$. However, this is also the most ethnically diverse group, with the highest percentage $(11.2 \%)$ of respondents outside of the two aforementioned ethnicities.

Those indirectly employed in tourism are the third largest of the four groups $(n=33)$, with the majority of respondents coming from Taupo Town $(75.5 \%)$ and no respondents from the townships of Mangakino, Turangi, or Wairakei. This group, along with the directly employed group, had the highest number of respondents $(33.3 \%)$ having lived in the district for 21 years or more. This group also recorded a low average age, with $30.3 \%$ of respondents being between 18-24 years old. Those indirectly employed in tourism are the only group to have more male than female respondents, however, the split is comparable, with $51.5 \%$ and $45.5 \%$ respectively. Although NZ European is the most dominant ethnicity $69.7 \%$, the indirectly employed group has the highest percentage of NZ Mãori respondents (27.3\%).

The group with no employment relationship to tourism is the second biggest group ( $n$ =45). It has the highest percentage of people coming from Taupō Town (82.2\%) and the highest percentage of people having lived in the district for 11-20 years (28.9\%). This group also has the highest number of respondents aged 45-54 years (28.9\%), and the lowest number of respondents aged $18-24$ years (4.4\%). NZ European is once again the most common ethnicity (77.8\%). This group has the highest percentage of Asian respondents (4.4\%).

Lastly, those not in employment is the smallest of the four groups $(n=32)$. As with all other groups, the majority of respondents (81.2\%) live in Taupō Town, however it also has the highest percentage of respondents living in Waitahanui, at 9.4\%. This group also has the highest number (18.8\%) of respondents living in the district for less than 1 year and the highest number of respondents aged 65 years and above (56.2\%). As with the other three groups, $N Z$ European is the dominant ethnicity $(84.4 \%)$, however this group is the least ethnically diverse, with no respondents identifying in Pacific Islander or Asian ethnic groups.

All four groups have respondents who had participated in freedom camping in the last 10 years. Those directly employed in tourism have the highest rate of freedom camping experience, at $31.9 \%$. Additionally, approximately one fifth of respondents in the other three groups have participated in freedom camping, with $21.2 \%$ in the indirectly employed in tourism 
group, $20.0 \%$ in the employment has no relation to tourism group, and $21.9 \%$ in the not in employment group.

\subsection{Perceived Impacts of Freedom Camping}

This section details the perceived impacts of freedom camping according to the sample population using descriptive statistics. The impacts are measured in Q6, Q7, Q8 with 27 survey items (see Appendix B). The results indicate that some items are perceived as having a greater impact on the host community than others. Table 4.7, below, presents the percentage distribution of the responses to each survey item, as measured on a five-point Likert scale. The table also shows the overall mean and standard deviation $(S D)$ of each item.

Table 4.7: Freedom Camping Impacts

\begin{tabular}{|c|c|c|c|c|c|c|c|c|}
\hline & \multirow[t]{2}{*}{ Impacts } & \multicolumn{5}{|c|}{ Percentage of Responses } & \multirow[t]{2}{*}{ Mean $^{\mathbf{a}}$} & \multirow[t]{2}{*}{ SD } \\
\hline & & 1 & 2 & 3 & 4 & 5 & & \\
\hline Q6(A) & $\begin{array}{l}\text { I think freedom camping enhances the } \\
\text { community's cultural identity }\end{array}$ & 26.4 & 13.7 & 25.3 & 23.6 & 11.0 & 2.79 & 1.35 \\
\hline Q6(B) & $\begin{array}{l}\text { I think freedom camping increases the } \\
\text { level of crime in the community }\end{array}$ & 18.1 & 20.3 & 36.3 & 21.4 & 3.8 & 2.73 & 1.11 \\
\hline Q6(C) & $\begin{array}{l}\text { I think freedom camping causes friction } \\
\text { between the community and tourists }\end{array}$ & 7.1 & 10.4 & 14.2 & 41.2 & 26.4 & 3.69 & 1.18 \\
\hline Q6(D) & $\begin{array}{l}\text { I think freedom camping causes } \\
\text { congestion in public spaces }\end{array}$ & 10.4 & 13.2 & 19.8 & 25.3 & 31.3 & 3.54 & 1.33 \\
\hline Q6(E) & $\begin{array}{l}\text { I think freedom camping enables me to } \\
\text { interact with other cultures }\end{array}$ & 12.6 & 8.8 & 23.6 & 28.6 & 26.4 & 3.47 & 1.31 \\
\hline Q6(F) & $\begin{array}{l}\text { I think freedom camping puts pressure on } \\
\text { public facilities and infrastructure }\end{array}$ & 7.1 & 13.2 & 8.8 & 28.0 & 42.9 & 3.86 & 1.30 \\
\hline Q6(G) & $\begin{array}{l}\text { I think freedom camping negatively } \\
\text { impacts on my day to day life }\end{array}$ & 44.0 & 11.5 & 27.5 & 12.1 & 4.9 & 2.23 & 1.27 \\
\hline Q6(H) & $\begin{array}{l}\text { I think freedom camping disrupts the } \\
\text { peace and tranquility of recreational parks }\end{array}$ & 17.6 & 13.7 & 20.3 & 28.6 & 19.8 & 3.19 & 1.38 \\
\hline Q6(I) & $\begin{array}{l}\text { I think freedom camping leads to } \\
\text { overcrowding }\end{array}$ & 14.3 & 12.1 & 22.0 & 26.9 & 24.7 & 3.36 & 1.35 \\
\hline Q7(A) & $\begin{array}{l}\text { I think freedom camping negatively } \\
\text { impacts the natural environment }\end{array}$ & 6.0 & 8.2 & 15.4 & 40.1 & 30.2 & 3.80 & 1.14 \\
\hline Q7(B) & $\begin{array}{l}\text { I think freedom camping supports the } \\
\text { development of public infrastructure }\end{array}$ & 18.1 & 15.9 & 37.9 & 15.9 & 12.1 & 2.88 & 1.23 \\
\hline Q7(C) & $\begin{array}{l}\text { I think freedom camping causes physical } \\
\text { pollution }\end{array}$ & 3.8 & 7.7 & 11.0 & 40.1 & 37.4 & 3.99 & 1.07 \\
\hline Q7(D) & $\begin{array}{l}\text { I think freedom camping causes noise } \\
\text { pollution }\end{array}$ & 14.3 & 15.4 & 33.0 & 24.2 & 13.2 & 3.07 & 1.22 \\
\hline Q7(E) & $\begin{array}{l}\text { I think freedom camping has increased the } \\
\text { amount of litter }\end{array}$ & 4.9 & 3.3 & 12.6 & 29.7 & 49.5 & 4.15 & 1.09 \\
\hline
\end{tabular}




\begin{tabular}{|c|c|c|c|c|c|c|c|c|}
\hline $\mathrm{Q} 7(\mathrm{~F})$ & $\begin{array}{l}\text { I think freedom camping leads to the } \\
\text { destruction of property }\end{array}$ & 13.7 & 7.7 & 32.4 & 23.6 & 22.5 & 3.34 & 1.29 \\
\hline Q7(G) & $\begin{array}{l}\text { I think freedom camping increases } \\
\text { vandalism }\end{array}$ & 18.1 & 15.4 & 36.8 & 15.4 & 14.3 & 2.92 & 1.27 \\
\hline Q7(H) & $\begin{array}{l}\text { I think freedom camping leads to the } \\
\text { maintenance of public spaces }\end{array}$ & 7.1 & 11.0 & 23.1 & 26.9 & 31.9 & 3.65 & 1.23 \\
\hline Q7(I) & $\begin{array}{l}\text { I think freedom camping is harmful to } \\
\text { local wildlife }\end{array}$ & 12.1 & 15.9 & 28.0 & 25.3 & 18.7 & 3.23 & 1.27 \\
\hline Q7(J) & $\begin{array}{l}\text { I think freedom camping causes parking } \\
\text { and traffic problems }\end{array}$ & 9.3 & 16.5 & 13.7 & 34.1 & 26.4 & 3.52 & 1.30 \\
\hline Q7(K) & $\begin{array}{l}\text { I think freedom camping leads to the } \\
\text { creation of recreational parks }\end{array}$ & 16.5 & 15.9 & 36.8 & 19.2 & 11.5 & 2.93 & 1.22 \\
\hline Q8(A) & $\begin{array}{l}\text { I think freedom camping improves my } \\
\text { personal income }\end{array}$ & 48.4 & 9.9 & 23.1 & 12.1 & 6.6 & 2.19 & 1.33 \\
\hline Q8(B) & $\begin{array}{l}\text { I think freedom camping leads to } \\
\text { employment opportunities in the } \\
\text { community }\end{array}$ & 29.1 & 15.4 & 19.8 & 24.2 & 11.5 & 2.74 & 1.40 \\
\hline Q8(C) & $\begin{array}{l}\text { I think freedom camping is a drain on } \\
\text { community resources }\end{array}$ & 11.0 & 15.9 & 25.8 & 22.5 & 24.7 & 3.34 & 1.31 \\
\hline Q8(D) & $\begin{array}{l}\text { I think freedom camping increases the } \\
\text { cost of living }\end{array}$ & 22.0 & 15.9 & 38.5 & 15.4 & 8.2 & 2.72 & 1.21 \\
\hline Q8(E) & $\begin{array}{l}\text { I think freedom camping benefits local } \\
\text { businesses }\end{array}$ & 13.2 & 9.9 & 16.5 & 35.2 & 25.3 & 3.49 & 1.32 \\
\hline $\mathrm{Q} 8(\mathrm{~F})$ & $\begin{array}{l}\text { I think freedom camping attracts more } \\
\text { spending }\end{array}$ & 13.7 & 10.4 & 20.3 & 33.0 & 22.5 & 3.40 & 1.32 \\
\hline Q8(G) & $\begin{array}{l}\text { I think freedom camping is a form of } \\
\text { freeloading }\end{array}$ & 13.2 & 10.4 & 24.7 & 25.8 & 25.8 & 3.41 & 1.33 \\
\hline
\end{tabular}

${ }^{a}$ Scale: 1=Disagree; 2=Somewhat Disagree; 3=Neither Agree nor Disagree; 4=Somewhat Agree; 5=Agree $\mathrm{n}=182$

Bolded impacts discussed in detail

Respondents were given the option to record any other impacts. Many of the impacts recorded were already in the survey and included ideas such as mess, fires, foul language and drunken behaviour, polluting, and disrespecting the cultural significance of whenua.

When examining the distribution of the percentage of responses in Table 4.7, above, six items had over $30 \%$ of respondents answering in the Agree column. The item with the highest percentage of Agree responses is $Q 7(E)$ : I think freedom camping has increased the amount of litter, which has almost half the respondents (49.5\%) answer Agree and a further $29.7 \%$ select that they Somewhat Agree. It also has the second to lowest percentage of respondents selecting Disagree (4.9\%) out of all the items. Item $Q 6(F)$ : I think freedom camping puts pressure on public facilities and infrastructure has the second highest percentage of 'Agree' responses, with over two fifths (42.9\%) of respondents answering Agree and an additional 28.0\% answering Somewhat Agree. This item also has polarising responses, with 
only $8.8 \%$ of people selecting Neither Agree nor Disagree. Respondents also registered strong feelings towards item $Q 7(C)$ : I think freedom camping causes physical pollution. This item has over three quarters of responses in the Agree and Somewhat Agree columns, with $37.4 \%$ and $40.1 \%$ respectively. A similar result is shown for item $Q 7(A)$ : I think freedom camping negatively impacts on the natural environment, with over two thirds of respondents selecting either Agree or Somewhat Agree, with 30.2\% and 40.1\% respectively. Q6(D): I think freedom camping causes congestion in public spaces, and $Q 7(H)$ : I think freedom camping leads to the maintenance of public spaces, are the other two items to have over $30 \%$ in the Agree column, with $31.3 \%$ and $31.9 \%$, respectively. However, both items also contained comparably high percentages in the Somewhat Agree (25.3\% and 26.9\%) and Neither Agree nor Disagree $(19.8 \%$ and $23.1 \%)$ columns.

In Table 4.7 with regard to responses in the Disagree column, there are two items with percentages over $40.0 \%$ and an additional three items with percentages over $20.0 \%$. Item Q8(A): I think freedom camping improves my personal income has the highest percentage of Disagree responses out of all the items, with almost half (48.4\%) of the respondents selecting Disagree. This is followed by item $Q 6(G)$ : I think freedom camping negatively impacts on my day to day life, which has the second highest percentage of Disagree responses, at $44.0 \%$. Items Q8(B): I think freedom camping leads to employment opportunities in the community, and Q6(A): I think freedom camping enhances the community's cultural identity, both have Disagree as their most common responses, at $29.1 \%$ and $26.4 \%$ respectively. The third item with over $20 \%$ of responses in the Disagree column is $Q 8(D)$ : I think freedom camping increases the cost of living at 22.0\%. Further to these results, items Q8(B), Q6(A), and Q8(D) mentioned above all had a notable percentage of responses in the Neither Agree nor Disagree column, indicating that they are less polarising issues.

The results in Table 4.7, show that not all items produced definitive answers from the respondents. Nine items, Q6(B), Q7(B), Q7(D), Q7(F), Q7(G), Q7(I), Q7(K), Q8(C), and Q8(D), all have the majority of responses in the Neither Agree Nor Disagree column and thus recorded a mean value close to the midpoint of 3 - ranging from 2.72 to 3.34. Item $Q 7(B): I$ think freedom camping supports the development of public infrastructure has the highest Neither Agree nor Disagree response rate at 37.9\%.

When analysing the mean values in Table 4.7, the item with the highest mean and thus the highest level of agreement, is Q7(E) with 4.15. The next highest mean belongs to items 
Q7(C) and Q6(F), which have 3.99 and 3.89 respectively. Five other items have mean values over 3.50: Q7(A) with 3.80, Q6(C) with 3.69, Q6(D) with 3.54, Q7(H) with 3.65, and Q7(J) with 3.52. Conversely, there are only two items with notably low mean values, indicating high levels of disagreement. Item Q8(A) has the lowest mean value with 2.19, closely followed by item Q6(G) with 2.23. The standard deviation is similar across the items, with a range of only 0.33. The item with the lowest standard deviation is Q7(C) with 1.07 and the item with the highest standard deviation is Q8(B) with 1.40.

\subsection{Support of Freedom Camping}

This section examines the support of freedom camping by the sample population using descriptive statistics. The support of freedom camping is measured in Q9 through eight survey items (see Appendix B). The results from the support statement section show that respondents have varying opinions on how freedom camping should operate in the Taupō District. Table 4.8 , below, presents the percentage distribution of the responses to each survey item, as measured on a five-point Likert scale. The table also shows the overall mean and standard deviation $(S D)$ of each item.

Table 4.8: Freedom Camping Support

\begin{tabular}{|c|c|c|c|c|c|c|c|c|}
\hline & \multirow[t]{2}{*}{ Support Statement } & \multicolumn{5}{|c|}{ Percentage of Responses } & \multirow[t]{2}{*}{ Mean $^{\mathbf{a}}$} & \multirow[t]{2}{*}{ SD } \\
\hline & & 1 & 2 & 3 & 4 & 5 & & \\
\hline Q9(A) & $\begin{array}{l}\text { I think improving freedom camping facilities is } \\
\text { a waste of ratepayer money }\end{array}$ & 29.1 & 25.3 & 15.9 & 13.2 & 16.5 & 2.63 & 1.44 \\
\hline Q9(B) & $\begin{array}{l}\text { I am against new facilities that will attract more } \\
\text { freedom campers }\end{array}$ & 26.9 & 20.3 & 19.2 & 14.3 & 19.2 & 2.79 & 1.47 \\
\hline Q9(C) & $\begin{array}{l}\text { I think the overall benefits of freedom camping } \\
\text { outweigh the costs }\end{array}$ & 17.0 & 18.1 & 25.3 & 22.5 & 17.0 & 3.04 & 1.33 \\
\hline Q9(D) & $\begin{array}{l}\text { I think the local government should restrict } \\
\text { freedom camping more }\end{array}$ & 14.8 & 13.7 & 23.1 & 29.1 & 19.2 & 3.24 & 1.32 \\
\hline Q9(E) & $\begin{array}{l}\text { Planning by the government can control the } \\
\text { impact of freedom camping on the ecological } \\
\text { environment }\end{array}$ & 3.8 & 3.3 & 17.0 & 35.2 & 40.7 & 4.05 & 1.03 \\
\hline Q9(F) & $\begin{array}{l}\text { I would support local levies on freedom } \\
\text { camping }\end{array}$ & 11.0 & 6.6 & 23.6 & 26.4 & 32.4 & 3.63 & 1.30 \\
\hline Q9(G) & $\begin{array}{l}\text { Freedom campers should pay more than locals } \\
\text { to visit parks and outdoor recreation facilities }\end{array}$ & 26.9 & 11.0 & 20.3 & 22.0 & 19.8 & 2.97 & 1.49 \\
\hline Q9(H) & Freedom camping is a right for New Zealanders & 12.6 & 6.0 & 24.7 & 27.5 & 29.1 & 3.54 & 1.31 \\
\hline
\end{tabular}

a Scale: 1=Disagree; 2=Somewhat Disagree; 3=Neither Agree nor Disagree; 4=Somewhat Agree; $5=$ Agree $\mathrm{n}=182$

Bolded impacts discussed in detail 
When examining the percentage of responses in Table 4.8, two items had over $30 \%$ of respondents answering in the Agree column. The first item, with the highest percentage of Agree responses, is item $Q 9(E)$ : Planning by the government can control the impact of freedom camping on the ecological environment. Three quarters of respondents selected either Agree (40.7\%) or Somewhat Agree (35.2\%) for this item. It also has the lowest percentage of Disagree responses $(3.8 \%)$ across all of the items. Item $Q 9(F)$ : I would support local levies on freedom camping also registered high levels of agreement, with almost one third of respondents selecting Agree (32.4\%) and an additional 26.4\% selecting Somewhat Agree. The results for item $Q 9(H)$ : Freedom camping is a right for New Zealanders also show high levels of agreement, with over half of the respondents selecting either Agree (29.1\%) or Somewhat Agree (27.5\%), and only $12.6 \%$ selecting Disagree.

In contrast, the item with the highest percentage of both Disagree (29.1\%) and Somewhat Disagree (25.3\%) responses is $Q 9(A)$ : I think improving freedom camping facilities is a waste of ratepayer money. This is followed closely by items $Q 9(B)$ : I am against new facilities that will attract more freedom campers, and $Q 9(G)$ : Freedom campers should pay more than locals to visit parks and outdoor recreation facilities, both of which have over a quarter $(26.9 \%)$ of responses in the Disagree column.

However, strong opinions are not registered by respondents for all of the support items. The item with the least decisive result is $Q 9(C)$ : I think the overall benefits of freedom camping outweigh the costs, which has the highest percentage of responses of Neither Agree nor Disagree $(25.3 \%)$. However, the responses to this item were widely distributed, with similar percentages recorded across all the possible responses, with $17.0 \%$ for Disagree, $18.1 \%$ for Somewhat Disagree, $22.5 \%$ for Somewhat Agree, and 17.0\% for Agree.

Table 4.8, above, shows that the items predominately have mean values close to the midpoint of 3, representing Neither Agree nor Disagree. Item Q9(G) is the closest to the midpoint with a mean of 2.97, followed closely by Q9(C) with a mean of 3.04. The item with the highest mean and thus the highest level of agreement, is Q9(E), with 4.05. Conversely, Q9(A) has the lowest mean of 2.63, and thus the highest level of disagreement. The standard deviation is comparable across the items, with a range of 0.46 . The item with the lowest standard deviation is Q9(E) with 1.03 and the item with the highest standard deviation is Q9(G) with 1.49 . 
Next, the impact of freedom camping on Taupō District's destination image was examined. In Table 4.9, below, results of the perceived impact of freedom camping on the destination image of the Taupō District is displayed. The respondents were asked 'How has freedom camping impacted the destination image of Taupō District?', with the level of agreement by respondents measured on a five-point Likert scale (see Appendix B).

Table 4.9: Freedom Camping's Impact on The Destination Image of Taupō District ${ }^{\mathrm{a}}$

\begin{tabular}{lcr}
\hline \multicolumn{1}{c}{ Impact on Destination Image } & Frequency & Percent \\
\hline Worsened & 27 & 14.8 \\
Somewhat Worsened & 46 & 25.3 \\
Not Made a Difference & 65 & 35.7 \\
Somewhat Improved & 27 & 14.8 \\
Improved & 17 & 9.3 \\
Total & 182 & 100.0 \\
\hline $\begin{array}{l}\text { a "Please select which statement you agree with the most. How has freedom camping impacted the destination } \\
\text { image of Taupō District?" Scale: 1=Worsened; 2=Somewhat Worsened; 3=Not Made A Difference; 4=Somewhat } \\
\text { Improved; 5=Improved }\end{array}$
\end{tabular}

Overall, respondents had mixed views about the impact of freedom camping on the destination image. The most popular response was that freedom camping had Not Made a Difference to the destination image, with $35.7 \%$ respondents selecting this answer. However, the results tend towards freedom camping being perceived as having a negative impact on the destination image of Taupō District, with $40.1 \%$ respondents reporting it as Worsened $(14.8 \%)$ or Somewhat Worsened (25.3\%). Notably, only 9.3\% respondents thought that it had Improved the destination image. These results are supported by a comparison across employment groups. Table 4.10, below, shows a comparison of freedom camping's impact on Taupō District's destination image between the employment groups.

Table 4.10: Impact on The Destination Image Across Employment Groups ${ }^{\text {a }}$

\begin{tabular}{|c|c|c|c|c|c|c|c|c|c|c|}
\hline & \multicolumn{2}{|c|}{$\begin{array}{l}\text { Directly } \\
\text { Employed }\end{array}$} & \multicolumn{2}{|c|}{$\begin{array}{l}\text { Indirectly } \\
\text { Employed }\end{array}$} & \multicolumn{2}{|c|}{$\begin{array}{l}\text { Employment } \\
\text { No Relation }\end{array}$} & \multicolumn{2}{|c|}{$\begin{array}{l}\text { Not in } \\
\text { Employment }\end{array}$} & \multicolumn{2}{|c|}{ Overall } \\
\hline & Mean & SD & Mean & SD & Mean & SD & Mean & SD & Mean & SD \\
\hline Destination Image & 2.61 & 1.12 & 2.94 & 1.00 & 2.84 & 1.22 & 2.94 & 1.27 & 2.79 & 1.153 \\
\hline
\end{tabular}


The mean values of all groups are between 2.61 and 2.94, which is close to the overall sample mean of 2.79 , indicating that overall, respondents believe that the destination image has been worsened due to freedom camping. This also reflects that all groups have a similar outlook on freedom camping's impact on the Taupō District's destination image. The Directly Employed group have the most negatively skewed responses, with a mean value of 2.61. The standard deviation is comparable across the groups, with a range of only 0.27 from the lowest (1.00) to the highest (1.27).

A comparison between the desired number of freedom campers and the desired number of tourists in the Taupō District was used to assess resident's support for tourism. Respondents were asked the following statements, 'The number of Freedom Campers in the Taupō District...', and 'The number of Freedom Campers in the Taupo District...', with the level of agreement by respondents measured using a five-point Likert scale (see Appendix B). Table 4.11, below, displays the host community's desired number of freedom campers and desired number of tourists in the Taupō District.

Table 4.11: Desired Number of Freedom Campers and Tourists in The Taupō District ${ }^{\mathrm{a}}$

\begin{tabular}{|c|c|c|c|c|c|}
\hline \multicolumn{6}{|c|}{ Desired Number of Freedom Campers and Tourists } \\
\hline \multicolumn{3}{|c|}{ Freedom Campers } & \multicolumn{3}{|c|}{ Tourists } \\
\hline $\begin{array}{c}\text { The number of freedom } \\
\text { campers in the Taupo } \\
\text { District... }\end{array}$ & Frequency & Percent & $\begin{array}{c}\text { The number of tourists in } \\
\text { the Taupō District... }\end{array}$ & Frequency & Percent \\
\hline Should Decrease & 34 & 18.7 & Should Decrease & 11 & 6.0 \\
\hline Should Somewhat Decrease & 33 & 18.1 & Should Somewhat Decrease & 11 & 6.0 \\
\hline Is Appropriate & 87 & 47.8 & Is Appropriate & 63 & 34.6 \\
\hline Should Somewhat Increase & 20 & 11.0 & Should Somewhat Increase & 42 & 23.1 \\
\hline Should Increase & 8 & 4.4 & Should Increase & 55 & 30.2 \\
\hline Total & 182 & 100.0 & Total & 182 & 100.0 \\
\hline
\end{tabular}

There is a notable distinction between the host community's desired number of tourists, as compared to freedom campers. When examining the desired number of freedom campers, the most popular response is that the current amount of freedom campers Is Appropriate, with almost half of the respondents (47.8\%) selecting this answer. However, the overall response distribution tends towards the host community wanting freedom camping numbers to decrease, with both Should Decrease and Should Somewhat Decrease receiving $18.7 \%$ and $18.1 \%$, 
respectively. Additionally, only $4.4 \%$ of respondents agreed that the number of freedom campers Should Increase. When looking at the desired number of tourists in the Taupō District, the most popular response is also Is Appropriate (34.6\%). However, the response distribution for the desired number of tourists tends towards the host community wanting these numbers to increase, with just under a third of respondents (30.2\%) selecting Should Increase. Furthermore, both Should Decrease and Should Somewhat Decrease only received $6.0 \%$ each. These differences are reflected in the mean values, of which the mean value for desired number of freedom campers is 2.64 , and the mean value for desired number of tourists is 3.65 (see Table 4.12 below).

Table 4.12 displays a comparison between the desired number of freedom campers and tourists across the different employment groups. When examining the desired number of freedom campers, the mean values of all groups are between 2.51 and 2.94, which is close to the overall sample mean value of 2.64. The results from all groups indicate that they would like the nu,ber of freedom campers in the district to either stay the same or somewhat decrease. The Directly Employed group have the most negative response, with a mean value of 2.51 . Conversely, the Indirectly Employed group have the most positive response, with a mean value (2.94) close to the midpoint. The standard deviation for the desired number of freedom campers ranges by 0.19 from the lowest (0.96) to the highest (1.15). In contrast, the mean values of all groups for the desired number of tourists are between 3.38 and 3.94, which is close to the overall sample mean value of 3.65. The results from all groups indicate that they would somewhat like the number of tourists in the district to increase. The Directly Employed group have the most positive response, with a mean value of 3.94, while the Not in Employment group have the least positive response, with a mean value of 3.38. The standard deviation for the desired number of tourists ranges by 0.27 from the lowest (1.00) to the highest (1.27).

Table 4.12: Desired Numbers Across Employment Groups ${ }^{\text {a }}$

\begin{tabular}{lllllllllll}
\hline & $\begin{array}{l}\text { Directly } \\
\text { Employed }\end{array}$ & \multicolumn{2}{l}{$\begin{array}{l}\text { Indirectly } \\
\text { Employed }\end{array}$} & $\begin{array}{l}\text { Employment } \\
\text { No Relation }\end{array}$ & \multicolumn{2}{l}{$\begin{array}{l}\text { Not in } \\
\text { Employment }\end{array}$} & \multicolumn{2}{l}{ Overall } \\
& Mean & SD & Mean & SD & Mean & SD & Mean & SD & Mean & SD \\
\hline Freedom Campers & 2.51 & .96 & 2.94 & 1.06 & 2.62 & 1.15 & 2.66 & 1.04 & 2.64 & 1.05 \\
Tourists & 3.94 & 1.00 & 3.61 & 1.25 & 3.42 & 1.27 & 3.38 & 1.13 & 3.65 & 1.15 \\
\hline
\end{tabular}

a "Please select which statement you agree with the most. The number of Freedom Campers/Tourists in the Taupō District..." Scale: 1=Should Decrease; 2=Should Somewhat Decrease; 3=Is Appropriate; 4=Should Somewhat Increase; $5=$ Should Increase 


\subsection{Relationship Between Perceived Impacts and Employment Group}

To test social exchange theory (SET) and compare the perceptions of freedom camping impacts across the four employment groups examined in Section 4.2.2, parametric testing was conducted.

\subsubsection{Component Development}

A principal component analysis (PCA) was run using SPSS on the portion of the questionnaire measuring the perceived impacts of freedom camping, according to 182 residents of the Taupō District. The suitability of using a PCA for the data was assessed prior to the analysis. The PCA was run on the 27 impact items in Q7-Q9 of the survey (see Appendix B). A selection of items were reverse coded prior to the PCA to ensure response direction consistency. The items reverse coded were as follows; Q6(A), Q6(E), Q7(B), Q7(H), Q7(K), Q8(A), Q8(B), Q8(E) and Q8(F). Sampling adequacy was measured through Kaiser-MeyerOlkin (KMO) (Hadia et al., 2016). The KMO measure was 917 (see Table 4.13 below), thus substantially exceeding the minimum acceptable score of .5 (Kaiser, 1974). According to Kaiser (1974), measures of sampling adequacy above .9 are considered 'marvellous'. Additionally, Bartlett's Test of Sphericity was used to assess the strength of the relationship between items (Bartlett, 1954). Bartlett's Test was statistically significant ( $p<.0005)$, indicating that the data was acceptable to be factorised (Hadia et al., 2016).

Table 4.13: KMO and Bartlett's Test of Sphericity for Perceived Impacts

\begin{tabular}{lrr}
\hline \multicolumn{3}{c}{ KMO and Bartlett's Test } \\
\hline Kaiser-Meyer-Olkin Measure of Sampling Adequacy. & .917 \\
Bartlett's Test of Sphericity & Approx. Chi-Square & 2982.938 \\
& df & 351 \\
& Sig. & .000 \\
\hline
\end{tabular}

The PCA revealed five components that had eigenvalues greater than 1 , which explained $41.15 \%, 10.31 \%, 5.25 \%, 4.28 \%$ and $3.76 \%$ of the total variance respectively (see Table 4.14). A visual inspection of the scree plot indicated that two components should be retained based on the graph's inflection point (see Figure 4.2) (Cattell, 1966). In addition, it was recognised that a two-component solution met the interpretability criteria and made conceptual sense. Subsequently, two components were retained for further analysis. To aid in the interpretability of these components, a Varimax orthogonal rotation was employed. The two-component solution explained $51.5 \%$ of the total variance, with the first component (Component 1) having an eigenvalue equal to 11.111 and explaining $41.2 \%$ of the variance in 
the original data, and the second component (Component 2) having an eigenvalue equal to 2.784 and explaining $10.3 \%$ of the variance (see Table 4.14). Component 1 was identified as 'Environmental and Community Concerns' and Component 2 was identified as 'Personal and Community Benefits'. Component 1 consists of items that address potential issues from freedom camping, such as environmental damage and community pressures. Conversely, Component 2 addresses the potential benefits from freedom camping, such as cultural exchange opportunities, job opportunities, and economic gain.

Table 4.14 presents the rotated components, along with the variance explained by each component, known as their eigenvalue.

Table 4.14: Total Variance Explained

\begin{tabular}{|c|c|c|c|c|c|c|c|c|c|}
\hline \multicolumn{10}{|c|}{ Total Variance Explained } \\
\hline \multirow[b]{3}{*}{ Component } & \multirow{2}{*}{\multicolumn{3}{|c|}{ Initial Eigenvalues }} & \multicolumn{3}{|c|}{ Extraction Sums of Squared } & \multirow{2}{*}{\multicolumn{3}{|c|}{$\begin{array}{l}\text { Rotation Sums of Squared } \\
\text { Loadings }\end{array}$}} \\
\hline & & & & & Loading & & & & \\
\hline & Total & $\begin{array}{c}\% \text { of } \\
\text { Variance }\end{array}$ & $\begin{array}{c}\text { Cumulative } \\
\% \\
\end{array}$ & Total & $\begin{array}{c}\% \text { of } \\
\text { Variance }\end{array}$ & $\begin{array}{c}\text { Cumulative } \\
\% \\
\end{array}$ & Total & $\begin{array}{c}\% \text { of } \\
\text { Variance }\end{array}$ & $\begin{array}{c}\text { Cumulative } \\
\% \\
\end{array}$ \\
\hline 1 & 11.111 & 41.151 & 41.151 & 11.111 & 41.151 & 41.151 & 5.913 & 21.902 & 21.902 \\
\hline 2 & 2.784 & 10.310 & 51.461 & 2.784 & 10.310 & 51.461 & 4.425 & 16.387 & 38.289 \\
\hline 3 & 1.418 & 5.251 & 56.712 & 1.418 & 5.251 & 56.712 & 3.111 & 11.523 & 49.812 \\
\hline 4 & 1.157 & 4.283 & 60.995 & 1.157 & 4.283 & 60.995 & 2.356 & 8.724 & 58.536 \\
\hline 5 & 1.015 & 3.758 & 64.753 & 1.015 & 3.758 & 64.753 & 1.679 & 6.217 & 64.753 \\
\hline 6 & .873 & 3.233 & 67.987 & & & & & & \\
\hline 7 & .824 & 3.052 & 71.038 & & & & & & \\
\hline 8 & .731 & 2.708 & 73.747 & & & & & & \\
\hline 9 & .662 & 2.452 & 76.199 & & & & & & \\
\hline 10 & .610 & 2.259 & 78.457 & & & & & & \\
\hline 11 & .593 & 2.196 & 80.653 & & & & & & \\
\hline 12 & .556 & 2.060 & 82.714 & & & & & & \\
\hline 13 & .543 & 2.013 & 84.726 & & & & & & \\
\hline 14 & .492 & 1.821 & 86.547 & & & & & & \\
\hline 15 & .427 & 1.582 & 88.129 & & & & & & \\
\hline 16 & .414 & 1.533 & 89.662 & & & & & & \\
\hline 17 & .377 & 1.396 & 91.058 & & & & & & \\
\hline 18 & .355 & 1.314 & 92.372 & & & & & & \\
\hline 19 & .324 & 1.200 & 93.572 & & & & & & \\
\hline 20 & .315 & 1.166 & 94.739 & & & & & & \\
\hline 21 & .292 & 1.083 & 95.821 & & & & & & \\
\hline 22 & .245 & .906 & 96.727 & & & & & & \\
\hline 23 & .206 & .764 & 97.491 & & & & & & \\
\hline 24 & .196 & .725 & 98.215 & & & & & & \\
\hline 25 & .191 & .706 & 98.921 & & & & & & \\
\hline 26 & .153 & .567 & 99.488 & & & & & & \\
\hline 27 & .138 & .512 & 100.000 & & & & & & \\
\hline
\end{tabular}

Extraction Method: Principal Component Analysis. 
Figure 4.2, below, depicts the scree plot, which is a plot of the components against their respective eigenvalue. The inflection point, labelled, represents the point where the graph starts to level out, reflecting the decreasing contribution of the subsequent components to the total variance (Cattell, 1996).

Figure 4.2: Scree Plot and Inflection Point

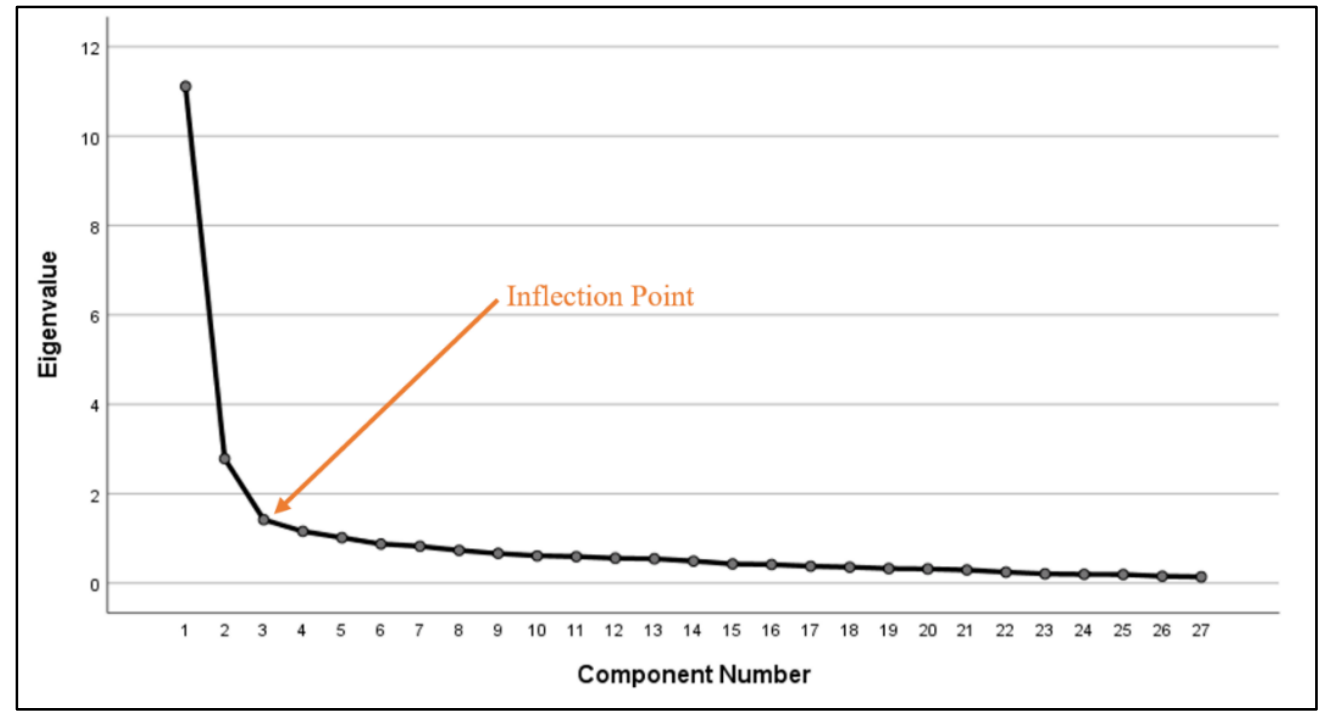

Table 4.15, below, displays the rotated component matrix and the component loadings for each item. Items are grouped based on their belonging to the resulting components. Additionally, within the components, items are ordered according their component loadings.

Table 4.15: Rotated Component Matrix with Loadings

\begin{tabular}{llr}
\hline & & \multicolumn{2}{c}{ Rotated Component Matrix $^{\mathbf{a}}$} & Component Loadings \\
\hline & Component 1: Environmental and Community Concerns & .796 \\
\hline Q7(J) & I think freedom camping causes parking and traffic problems & .790 \\
Q7(G) & I think freedom camping increases vandalism & .754 \\
Q7(A) & I think freedom camping negatively impacts on the natural environment & .748 \\
Q7(I) & I think freedom camping is harmful to local wildlife & .741 \\
Q6(D) & I think freedom camping causes congestion in public spaces \\
Q6(I) & I think freedom camping leads to overcrowding & .726 \\
Q7(F) & I think freedom camping leads to the destruction of property & .718 \\
Q6(H) & I think freedom camping disrupts the peace and tranquility of recreational & .713 \\
& parks & I think freedom camping is a drain on community resources
\end{tabular}


Q6(C) I think freedom camping causes friction between the community and tourists

Q6(F) I think freedom camping puts pressure on public facilities and $\quad .684$ infrastructure

Q7(D) I think freedom camping causes noise pollution

Q7(C) I think freedom camping causes physical pollution $\quad .668$

Q7(E) I think freedom camping has increased the amount of litter $\quad .668$

Q6(G) I think freedom camping negatively impacts on my day to day life $\quad .639$

Q8(D) I think freedom camping increases the cost of living $\quad .630$

Q6(B) I think freedom camping increases the level of crime in my community .630

Q8(G) I think freedom camping is a form of freeloading $\quad .630$

Q7(H)* I think freedom camping leads to the maintenance of public spaces ${ }^{\mathrm{b}} \quad-.412$

\section{Component 2: Personal and Community Benefits}

Q8(B)* I think freedom camping leads to employment opportunities in the $\quad .799$ community

Q8(E)* I think freedom camping benefits local businesses

Q8(F)* I think freedom camping attracts more spending

Q8(A)* I think freedom camping improves my personal income

Q7(B)* I think freedom camping supports the development of public infrastructure

Q6(E)* I think freedom camping enables me to interact with other cultures

Q6(A)* I think freedom camping enhances the community's cultural identity

Q7(K)* I think freedom camping leads to the creation of recreational parks

Extraction Method: Principal Component Analysis.

Rotation Method: Varimax with Kaiser Normalization

${ }^{\text {a }}$ Rotation converged in 3 iterations

${ }^{\mathrm{b}}$ Removed from future calculations

* Reverse Coded

The two components presented a clear grouping of items, with the exception of $Q 7(H)$ : I think freedom camping leads to the maintenance of public spaces, which did not fit neatly within either component (see Figure 4.3). This item had a negative component loading value of -.412 for Component 1 and no component loading value for Component 2. Due to this, item Q7(H) was removed from further analysis.

Figure 4.3, below, displays the component plot in rotated space to visually represent how the different items group together. 
Figure 4.3: Component Plot in Rotated Space

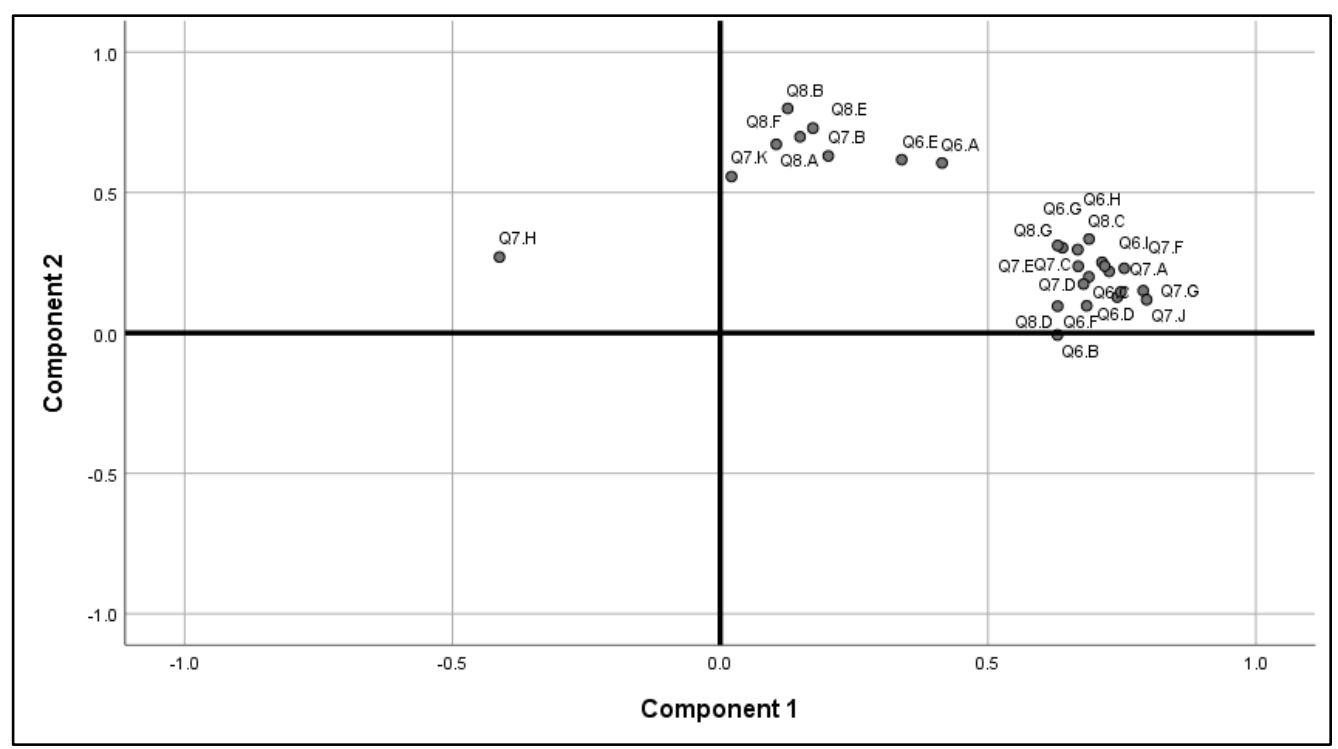

\subsubsection{Reliability Testing}

The two components extracted from the PCA were tested for reliability using Cronbach's alpha $(\alpha)$. The results showed a value of $\alpha=.948$ for Component 1 and $\alpha=.849$ for Component 2 (see Table 4.16 below). Both values exceeded $\alpha=.6$, which is commonly considered to be acceptable in exploratory research (Straub et al., 2004), thus displaying a high level of internal consistency.

Table 4.16: Reliability Statistics

\begin{tabular}{ccc}
\hline \multicolumn{3}{c}{ Reliability Statistics } \\
\hline Component & Cronbach's Alpha & Number of Items \\
\hline Component 1: Environmental and Community Concerns & .948 & 18 \\
Component 2: Personal and Community Benefits & .849 & 8 \\
\hline
\end{tabular}

\subsubsection{Component Comparison Between Groups}

To assess the extent to which each respondents' employment relationship with tourism influenced their perception of the impacts of freedom camping in the Taupō District and thus whether the assumptions made from social exchange theory applied in this context, one-way analysis of variance (ANOVA) tests were used.

A one-way ANOVA test was conducted to determine if the responses for Component 1, Environmental and Community Concerns, was different for groups based on their different employment relationships with tourism. Respondents were classified into four groups: directly 
employed in tourism $(n=72)$, indirectly employed in tourism $(n=33)$, employment has no relation to tourism $(n=45)$, and not in employment $(n=32)$. Normality was assessed visually using boxplots and it was determined that the data is approximately normally distributed (see Appendix E1). The box plots identified one outlier, respondent number 60, in the data set for Component 1. It was established that the outlier was not the result of a data entry error or a measurement error, and that it was a genuinely unusual data point. The one-way ANOVA was run using SPSS both with and without the outlier to determine if it made a difference to the results. The inclusion of the outlier did not appear to influence the result and, without a valid reason to exclude it, the outlier was kept in the analysis. Levene's test of homogeneity of variances was not significant $(p=.608$ ), thus indicating equal variance between groups (see Appendix E1). The mean value decreased from Directly Employed $(M=3.46, S D=0.83)$, to Employment No Relation $(M=3.37, S D=0.91)$, to Not In Employment $(M=3.20, S D=0.99)$, to Indirectly Employed $(M=3.16, S D=0.96)$ (see Appendix E1). However, the one-way ANOVA found that differences between these employment groups was not statistically significant, $F(3,178)=1.153, p=.329($ see Table 4.17$)$.

Table 4.17: One-way ANOVA (Environmental and Community Concerns - Employment Relationship)

\begin{tabular}{llrrrrr}
\hline \multicolumn{9}{c}{ ANOVA } & & & & \\
\hline & \multicolumn{1}{c}{ Sum of Squares } & df & Mean Square & F & Sig. \\
\hline Component 1 & Between Groups & 2.841 & 3 & .947 & 1.153 & .329 \\
& Within Groups & 146.173 & 178 & .821 & & \\
& Total & 149.014 & 181 & & & \\
\hline
\end{tabular}

A second one-way ANOVA test was conducted to determine if the results for Component 2, Personal and Community Benefits, was different for groups based on their different employment relationships with tourism. Respondents were again classified into the four groups: directly employed in tourism $(n=72)$, indirectly employed in tourism $(n=33)$, employment has no relation to tourism $(n=45)$, and not in employment $(n=32)$. Normality was assessed visually using boxplots and it was determined that the data is approximately normally distributed (see Appendix E2). The box plots identified one outlier, respondent number 3 , in the data set for Component 2. It was established that the outlier was not the result of a data entry error or a measurement error, and that it was a genuinely unusual data point. The one-way ANOVA was run using SPSS both with and without the outlier to determine if it made a difference to the results. The inclusion of the outlier did not appear to influence the 
result and, without a valid reason to exclude it, the outlier was kept in the analysis. Levene's test of homogeneity of variances was not significant $(p=.509)$, thus indicating equal variance between groups (see Appendix E2). The mean value decreased from Directly Employed $(M=$ $2.99, S D=.93)$, to Not In Employment $(M=2.97, S D=.79)$, to Employment No Relation $(M=$ 2.88, $S D=.72)$, to Indirectly Employed $(M=2.79, S D=.96)$ (see Appendix E2). However, the one-way ANOVA found that differences between these employment groups was not statistically significant, $F(3,178)=.491, p=.689($ see Table 4.18$)$.

Table 4.18: One-way ANOVA (Personal and Community Benefits - Employment Relationship)

\begin{tabular}{|c|c|c|c|c|c|c|}
\hline \multicolumn{7}{|c|}{ ANOVA } \\
\hline & & Sum of Squares & $\mathrm{df}$ & Mean Square & $\mathrm{F}$ & Sig. \\
\hline \multirow[t]{3}{*}{ Component 2} & Between Groups & 1.100 & 3 & .367 & .491 & .689 \\
\hline & Within Groups & 132.979 & 178 & .747 & & \\
\hline & Total & 134.079 & 181 & & & \\
\hline
\end{tabular}

\subsection{Open-ended Question Analysis}

This section uses a thematic analysis to examine the responses to the open-ended survey question (Q12), which asked respondents to provide their overall thoughts about freedom camping in New Zealand (see Appendix B). The responses reflect a diversity of opinions, however there are several key themes that arose from respondents, indicating that multiple respondents felt strongly about these aspects. Of the 182 surveys, 143 respondents provided comments for Q12.

The theme mentioned the most was Facilities, with 25 respondents (17.5\%) referring to facilities in their comments. Most of the commentary surrounding facilities either highlighted the need for more facilities at freedom camping areas or suggested that freedom campers should be paying to maintain facilities, with comments such as 'I totally agree with freedom camping provided they have the correct facilities on board', and '[needs] more public bathrooms/better facilities at the areas'. After this, the theme next most referred to was Environment, with 20 respondents (14\%) centring their comments around it. Most of these comments showed concern for freedom camping's impact on the environment, with one respondent describing freedom camping as an 'environmental disaster' and equating it to being worse than dairy farming, while another stated that it 'leads to environmental destruction'. 
Conversely, some comments indicated a positive connection between freedom camping and the environment, with one respondent stating that freedom camping is 'a great way of connecting to and enjoying our environment'. Other popular commentary surrounds the issue of freedom camping leaving behind rubbish. Almost one quarter $(23.1 \%)$ of respondents mentioned the words Rubbish, Litter, Trash, or Waste as an issue. One respondent stated their 'main concern is the amount of rubbish', suggesting that this is a common concern across the host community. Overseas/foreign freedom campers were also a notable subject of discussion, with some comments alluding to freedom campers from outside of the country as being the ones who are disrespectful, with comments such as 'freedom camping as a New Zealander should be our right... tourist freedom campers seem to ruin it for the rest of freedom campers', and 'foreign travellers can be very disrespectful to our culture and environment'.

Another emergent aspect commented on was the management and control of freedom camping impacts. Local council and government were mentioned in the comments of 11 respondents $(7.7 \%)$, with comments suggesting that these regulators need to do more to manage freedom camping and protect destinations where it occurs, 'the government needs to put more systems and facilities in place to minimise the effects on the environment'. Several comments suggested that respondents do not mind freedom camping occurring if certain conditions are met, with several stating 'as long as they're tidy I'm okay with it', 'no worries if they keep the place clean', and 'no problem with freedom campers as long as they respect the environment and are self-contained'. Other respondents feel that more significant changes are needed before they can support it as a legitimate source of accommodation, with respondents stating freedom camping, 'needs to be monitored more closely', 'needs to be more maintenance of sites', and 'needs more controls.' A few respondents (8.4\%) also suggested that small levies or fees should be introduced to reduce the burden on the ratepayers in the destination, commenting that ' $a$ small levy may help pay for facilities, maintenance etc', and 'should be a small fee for camping to maintain the area, clean, tidy'.

\subsection{Summary}

Chapter Four has presented the research findings. It summarised the characteristics of the sample population and compared these with the 2018 Census data to evaluate the representation of the sample. The key freedom camping impacts according to the host community were identified, based on the percentage distribution and mean values of responses. Following this, the overall support of freedom camping was evaluated. A PCA was conducted 
on the impact items, and the four employment groups were tested for differences in their perceptions using one-way ANOVA tests. Lastly, the open-ended question was thematically analysed to extract keywords and note the overall views that the host community has about freedom camping in New Zealand. 


\section{CHAPTER FIVE: DISCUSSION}

\subsection{Introduction}

Chapter Five discusses the findings from the previous chapter to address the thesis research objectives. Using a combination of concepts from tourism impact literature, freedom camping literature, social exchange theory, and stakeholder theory, inferences are made to interpret and discuss the outcomes of the statistical tests. The discussion is structured by the research objectives. Firstly, the perceived impacts from freedom camping are analysed, with key concerns highlighted. Following this, the perceptions of the employment groups are compared, along with explanations for the results. Next, the support of freedom camping is reviewed. Finally, the implications of the findings are considered. Throughout this chapter, extracted quotations from Q12 of the survey (see Appendix B) will be used to supplement the findings, and add depth to the discussion.

\subsection{Research Objectives Revisited}

As stated in Section 1.5, the aim of this research is to understand the host community's perceptions of the impacts of freedom camping impacts on the Taupō District, through the lens of social exchange theory (SET), and to evaluate the host community's overall support of freedom camping. Subsequently, the following research objectives were developed:

1. Determine how the host community of the Taupō District perceives the impacts of freedom camping.

2. Examine how these perceptions differ depending on the host community members' employment relationship with the tourism industry using SET. Four host community groups are identified for this purpose - those directly employed in tourism, those indirectly employed in tourism, those whose employment has no relation to tourism, and those not in employment.

3. Evaluate the host community's overall support of the freedom camping industry.

\subsection{Host Community Perceptions of Freedom Camping Impacts}

This section focuses on the first research objective. The survey results of this study show that the host community perceive freedom camping as having both positive and negative impacts on the Taupō District. The most negatively perceived impacts of freedom camping are largely associated with the environment, with the host community in overall agreement that 
freedom camping can negatively impact on the natural environment (Q7(A)). The most considerable impact, with the highest level of agreement from the host community, is that freedom camping increases the amount of litter $(\mathrm{Q} 7(\mathrm{E}))$. This perception aligns with the studies cited in Section 2.5.4, which suggest that litter is one of the most significant complaints surrounding freedom camping in New Zealand in recent years (Angus \& Associates, 2017; DIA, 2016). Additionally, it is consistent with the tourism literature in Section 2.5.2, which details litter to be a prominent perceived impact of tourism (Andereck et al., 2005; Brunt \& Courtney, 1999; Lankford, 1994; Liu \& Var, 1986; Okech, 2010). The association between freedom camping and increased litter was further illustrated by respondents in the open-ended question analysed in Section 4.7, with almost one quarter of comments mentioning litter as a concern. One respondent stated that freedom camping 'creates more dirty litter', while another said they 'worry about the environmental impact by waste and rubbish'. Moreover, freedom camping is agreed to cause substantial physical pollution $(\mathrm{Q} 7(\mathrm{C}))$, with notable commentary surrounding human waste being found in freedom camping locations. One respondent declared that '[freedom campers] are dirty and leaving stuff wherever they park up', while another emphasised '[freedom campers] often disrespect the environment by using wooded areas for toilets'.

Conversely, the impact of noise pollution was found to negligible (Q7(D)). While tourism literature suggests that noise pollution, along with air and water pollution, can be an issue for residents living in tourism destinations (Andereck et al., 2005; Lankford, 1994; Liu \& Var, 1986; Okech, 2010), the host community of the Taupō District had no strong feelings about noise being an issue. This may be because the open freedom camping areas in the Taupo District are in public reserves on the outskirts of townships, and most respondents lived inside townships where both self-contained and non-self-contained freedom camping is prohibited. As Collins et al. (2018) suggests, issues tend to arise when freedom camping is audible and visible to the residents, rather than when it occurs away from residents. Alternatively, negative perceptions of environmental impacts can be expected, as freedom camping tends to be restricted to natural outdoor areas, where the impact is more visible.

Results of this study also found that the activity of freedom camping is perceived to put public facilities and infrastructure under pressure (Q6(E)). Multiple respondents mentioned the need for more facilities to manage freedom camping waste, and that freedom campers need to pay to contribute to the maintenance of facilities. Respondents reported freedom camping, 'puts pressure on public facilities' and one suggested that 'maybe they need to pay a tax to contribute 
to roading and upgrading of toileting facilities.' Another stated that 'any travellers should [...] use facilities appropriately and contribute to the cost of maintaining the facilities they use'. The concern surrounding the pressure freedom camping puts on public infrastructure and facilities is consistent with the attitude that freedom campers use what is freely available without contributing to the cost of maintenance or development, which instead it falls on the residents to pay the associated expenses through rates and taxes (Collins et al., 2018). This was emphasised by one respondent who stated, '[freedom camping] needs to be managed and paid for by those using space that NZ ratepayers are being charged for', with another asserting freedom camping 'is a stress on local infrastructure paid by ratepayers'. However, despite the freedom campers not contributing the infrastructure they use, respondents did agree that freedom camping leads to the maintenance of public spaces $(\mathrm{Q} 7(\mathrm{H}))$.

As discussed in Section 2.5.4, literature suggests that sites where freedom camping occurs are often considered contested, as a multitude of activities can be competing with one another in the same space. Furthermore, freedom camping can only succeed when there is a balance of environmental and recreational management of a site (Collins et al., 2018; DoC, 2017). This study found site competition to be a notable issue regarding freedom camping impacts, with respondents largely agreeing that freedom camping leads to both overcrowding (Q6(I)) and congestion in public places (Q6(D)). One respondent found that 'public spaces become unavailable for casual users as freedom campers take them over', while another stated that freedom camping 'takes up best areas in some locations. Pushes locals out of scenic areas'. Additionally, it is perceived that public spaces cannot keep up with the demand from freedom camping, with one respondent stating, 'many natural sites in and around Taupō District are at or beyond capacity'. This perception was also evident in the media, with one article on freedom camping in Turangi detailing how freedom campers were inhabiting areas and spreading their belongings everywhere (Shand, 2016 $6^{\mathrm{a}}$ ). While initiatives to combat overcrowding have been introduced, such as the CamperMate App mentioned in Section 2.3.3, the issue is still prevalent, indicating that either these initiatives are not effective enough, or that more time is needed for host community perceptions to change. Moreover, findings of this study suggest that the host community perceive that freedom camping causes traffic and parking problems $(\mathrm{Q} 7(\mathrm{~J}))$. Freedom camping in New Zealand is predominately confined to motor vehicles and thus where the activity occurs, there will consequently be increased road usage. One respondent mentioned their concern about 'campervans parking in car spaces in town', alluding to the perception that freedom campers are occupying what is considered to be 
resident spaces. However, it is important to note that overcrowding and traffic problems are not unique to freedom camping, but tourism in general. As previously stated, the Taupō District is renowned for its natural attractions and thus is a popular holiday destination in New Zealand (see Section 1.4.3). In addition to the location's popularity, New Zealand relies heavily on roads for transportation, and the use of motor vehicles is popular for both international and domestic tourists to travel the country. Thus, these impacts are not limited to freedom camping. These results are also consistent with prior tourism studies which identify issues of traffic, congestion, and overcrowding as major concerns (Andereck et al., 2005; Brunt \& Courtney, 1999).

This study shows no clear indication that residents perceive that freedom camping increases vandalism $(\mathrm{Q} 7(\mathrm{G}))$ or the level of crime in the community $(\mathrm{Q} 6(\mathrm{~B}))$. However, there is slight agreement amongst the host community that freedom camping does lead to the destruction of property $(\mathrm{Q} 7(\mathrm{~F}))$. This finding ties back to the aforementioned issues of litter and physical pollution at freedom camping sites.

The findings of this study show that freedom camping does not have consequential impacts on the cultural identity of the Taupō District (Q6(A)). However, it is thought to somewhat allow residents to interact with other cultures (Q6(E)), presumably as freedom camping is popular with international tourists. The cultural identity impacts of freedom camping were perhaps not so significant to the host community, as the tourism industry is quite mature in the Taupō District and the region has already been shaped by it. Furthermore, cultural impacts as a whole did not have a dedicated section in the survey as they were grouped with wider social impacts, and thus, they may have been less obvious for the respondents. Only two respondents commented on culture in the open-ended question, both of whom found it to be negatively impacted by freedom camping. One stated, 'I find foreign travellers can be very disrespectful to our culture and environment', however, this does not necessarily pertain solely to freedom campers, as the respondent references foreign travellers as a collective.

Generally, tourism literature suggests that the economic impacts of tourism on a destination are the most positively perceived by residents (Tosun, 2002). However, this study found the economic impacts from freedom camping to be less significant than those of tourism in other studies mentioned in Section 2.5.3, with most economic-based impacts recording neutral results (see Table 4.7). Freedom camping is perceived to have slight benefits for local businesses based on the survey results $(\mathrm{Q} 8(\mathrm{E}))$, however, the commentary surrounding the 
impact on local businesses was largely negative. It centred on freedom camping taking away from the commercial campsites and alternative accommodation providers in the area, with one respondent stating, 'it takes away business from actual holiday parks/camps who must adhere to council compliance to operate'. The experience of another respondent is that freedom camping in Taupō District doesn't contribute to complimentary tourism businesses either: ' $I$ run a tourist business and look after a carpark where freedom camping is allowed. We get no business from freedom campers but do a lot of work to keep the carpark tidy'.

Another perception of the host community is that freedom camping did not create employment opportunities in the community $(\mathrm{Q} 8(\mathrm{~B}))$. As freedom camping sites are predominately managed by local council there are no recognisable jobs being created as a result of freedom camping, as the accommodation aspect does not generate income in itself. This also suggests that residents do not perceive freedom camping to be a sizeable enough segment of the tourism industry in Taupō District to generate jobs in other spheres, such as hospitality. This result contrasts with tourism literature, which finds that tourism has a significant influence on job creation and employment opportunities in a destination (Andereck et al., 2005; Lankford, 1994; Liu \& Var, 1986; Johnson et al., 1994).

The findings suggest that the host community agree freedom camping brings a slight increase in spending $(\mathrm{Q} 8(\mathrm{~F}))$, even though freedom campers save money on accommodation costs. This perception is illustrated through one respondent who stated, 'by allowing them to freedom camp they are able to spend more money on tourism activities'. Freedom camping is not perceived to have an impact on the cost of living for the host community (Q8(D)), which can be the case for other forms of tourism (Liu \& Var, 1986). There was strong agreement however, that freedom camping did not improve the host community's personal income (Q8(A)). Additionally, just over half of the respondents were somewhat in agreement that freedom camping was a form of freeloading $(\mathrm{Q} 8(\mathrm{G})$ ) (see Table 4.7). These findings largely fit with the reported perceptions of freedom camping being a low-cost activity that does not significantly benefit the local economy (Collins et al., 2018; Kearns et al., 2017), even though data from the International Visitors Survey (IVS) shows that freedom campers do in fact have a significant economic contribution (Fieger et al., 2019). The IVS shows that freedom campers' economic contribution is considered comparable to tourists staying in homestays, B\&B's, and campsites/national parks (Fieger et al., 2019). Furthermore, almost half of the respondents somewhat agreemed that freedom camping is a drain on community resources $(\mathrm{Q} 8(\mathrm{C}))$, which 
ties back to the discussion of public facilities and infrastructure and who these are, or should be, funded by.

The results of the study found that freedom camping is creating friction between the host community of Taupō District and tourists (Q6(C)) (see Table 4.7). One reason for this is that it may be hard for locals to differentiate between freedom campers and other tourists in certain situations, and therefore any hostilities residents feel due to the negative impacts of freedom camping may be applied to tourists as a collective. A particular example of this is Hipapatua Reserve/Reid's Farm, where there can be a variety of tourists and locals sharing the same space and public facilities. As stated in Section 2.7, stakeholders that are active within a community, such as tourists and freedom campers, have a social contract with that community that must be maintained (Robson \& Robson, 1996). When friction between stakeholders and the host community is not dealt with, any negative feelings surrounding freedom camping's impacts can be transferred onto other tourists in a destination, and the tourism industry risks losing its social license to operate (SLO) in that destination. Thus, emphasising the need to focus on improving how freedom camping operates. In this study however, despite the negative impacts noted by comments from respondents, the survey results found that very few host community members think that freedom camping negatively impacts on their day-to-day life $(\mathrm{Q} 6(\mathrm{G}))$.

\subsection{Employment Groups Impact on Perceptions}

This section is centred on the second research objective. As discussed in Section 2.6, literature on social exchange theory (SET) suggests that residents who benefit financially from the tourism industry will have a more positive outlook on tourism impacts in a destination than those who gain no direct financial benefits (Andereck et al., 2005; Ap, 1992; Tosun, 2002). In the context of this research, it was therefore assumed that those directly and indirectly employed in tourism would have a more positive perception of freedom camping's impacts on the Taupō District over those whose employment is not related to tourism and those not in employment. This assumption was made as freedom campers are a subset of tourists, and therefore also bring economic contributions to the destinations in which they stay. While it is recognised that freedom campers do not contribute to the economy through paying for accommodation, they do spend money on supplies and services, such as on food and drink, fuel, attractions, and activities (Collins et al., 2018; Kearns et al., 2017). As discussed in Section 2.3.2, visitors who freedom camp in New Zealand contribute more than half a billion 
dollars to the economy each year (MBIE, 2019 $)$. To determine SET's impact on the host community's perceptions, one-way ANOVA tests were conducted on the two components identified through the PCA in Section 4.6.

Component 1, labelled Environmental and Community Concerns, consists of the impact items that are recognised as potential issues from freedom camping, such as environmental damage and community pressures. Component 2, labelled Personal and Community Benefits, encompasses the potential benefits of freedom camping, such as economic gain and exchange opportunities. The one-way ANOVA results in Section 4.6.3 showed the differences between the four employment groups for both Component 1, Environmental and Community Concerns, and Component 2, Personal and Community Benefits, were not statistically significant. This indicates that SET did not apply to the activity of freedom camping in this study when looking at host community members' employment relationship.

There are a variety of explanations as to why there are no significant differences in the perceptions between the four groups in this research. Firstly, SET has only been tested in the context of tourism, not freedom camping, and therefore the same principles have not been shown to apply. This could be because freedom camping is only a subset of tourism and has its own complexity and nuance due to the nature of the activity. It is recognised that not all who work in tourism benefit from freedom camping, particularly those who work in the accommodation sector. Further, the 'freedom' aspect of freedom camping is not only related to the flexibility the activity offers but also to financial freedoms (Kearns et al., 2017). Freedom campers avoid paying campsite fees by staying on public land, which is funded by local authorities. Therefore, the economic benefits for those employed in tourism is not universally applicable. As the title of freedom camping includes the word 'free', people who do experience economic benefits from freedom camping may simply not perceive this to be the case.

Secondly, it is acknowledged that the group containing those directly employed in tourism includes those who are employed in the accommodation sector. As freedom camping is a form of accommodation, it therefore can be considered direct competition to alternative accommodation offerings, particularly by commercial campgrounds (Collins et al., 2018). As such, accommodation workers are more likely to view freedom camping, and its impacts, in a negative light. This would consequently influence the results for this group, especially as accommodation workers accounted for almost one third of the directly employed group (see Table 4.4). Furthermore, the questionnaire only asked people about their current employment 
at the time of surveying and did not account for people's past employment nor their aspirational employment. As such, it is possible that people's perceptions were skewed as they may have previously had economic benefit from tourism or may be likely to have economic benefit from tourism in the future.

Additionally, despite its long history in New Zealand (Collins \& Kearns, 2010), freedom camping as a defined tourism activity is only in its infancy. Therefore, it is possible that there is a general lack of understanding about freedom camping. People may not distinguish freedom camping as its own sector and thus the impacts that it causes, both positive and negative, may not be salient to them. This is supported by comments from a respondent who said, 'I personally don't know much about it, sounds like a fun idea for people to try but does need the proper facilities to ensure the cleanliness of NZ' and another who said 'not that knowledgeable about the issue so it's hard to have an opinion on the matter'.

Lastly, people's perceptions are not only shaped by their own experiences but also by other external influences, such as the media and word of mouth (WOM) from family and friends. In essence, WOM is recognised as a process of personal influence, where interpersonal communications between a sender and a receiver can change the receiver's perceptions or behaviours (Merton, 1968). The questionnaire was not restricted to individuals who had personal freedom camping experiences and therefore some of the respondents may have only been able to answer based on what they knew of freedom camping from other sources. As discussed in Section 2.4, there are a lot of negative impacts of freedom camping in the Taupō District presented in the media (Kirkeby, 2016; McMichael, 2017; Shand, 2016 ${ }^{\mathrm{a}}, 2016^{\mathrm{b}}$ ). Thus, these external influences could be a contributing factor to people's negative perceptions of freedom camping that goes beyond their own personal experiences with it.

It is evident that perceptions of freedom camping are complex and influenced by a variety of factors. Therefore, the application of SET to freedom camping needs to be examined further. One avenue for future research would be to separate out those directly employed in tourism who have competing interests with freedom camping, such as commercial campgrounds and other accommodation providers, as their own distinct group.

\subsection{Support of Freedom Camping}

This section focuses on the third research objective. The survey results from this study show that the host community have varying levels of support for freedom camping in the Taupō 
District. Respondents agreed that planning by the Government can control the impact of freedom camping on the ecological environment (Q9(E)), which is consistent with results from tourism literature (Liu \& Var, 1986). This suggests that the residents do believe Government intervention is both needed, and wanted, to manage freedom camping impacts.

Additionally, support was shown for the idea of introducing local levies for freedom camping $(\mathrm{Q} 9(\mathrm{~F}))$. This result coincides with the commentary mentioned around the introduction of fees to pay for the cost of maintenance. Respondents suggested ideas for fees, such as a compulsory levy for hire companies who rent out their vehicles to freedom campers. Alternatively, one respondent suggested that freedom campers could pay a levy when entering the country, similar to the $\$ 35$ International Visitor Conservation and Tourism Levy (IVL) that was introduced by the Government in July 2019. The IVL directly funds the protection of the environment and public infrastructure (MBIE, 2020). However, despite supporting the idea of introducing levies, there was no consensus about freedom campers paying more than locals to visit parks and outdoor recreation facilities $(\mathrm{Q} 9(\mathrm{G}))$. This result is consistent with tourism literature, which found there to be an even split between those who wanted tourists to pay more than locals to visit these areas and those who did not (Perdue et al., 1990).

Since the Freedom Camping Act 2011 (FCA) was introduced, there have been measures put in place by the Taupō District Council to both restrict and prohibit freedom camping in certain areas in the Taupō District. The 2017 Bylaw saw freedom camping in areas such as Ferry Road become prohibited. As well as this, the Department of Conservation (DoC) closed three sites to freedom camping (DoC, 2017; Taupō District Council, 2017). However, despite these measures, there was still some agreement from the host community that the Government should restrict freedom camping more (Q9(D)). This viewpoint was backed up in the commentary with respondents stating, 'perhaps more restrictions can be put in place', and that 'there should be more rules and restrictions to where people can freedom camp'. Nonetheless, it is important to note that there were still many respondents who felt it did not need more restricting or that the current restrictions were adequate.

Overall, this research indicates that the host community of Taupō District are not against new facilities that will attract more freedom campers (Q9(B)), nor do they think that improving freedom camping facilities is a waste of ratepayer money (Q9(A)).

Freedom camping was once considered the norm in New Zealand (Collins \& Kearns, 2010) and therefore it is unsurprising to see that in general, respondents felt that the activity of 
freedom camping is a right for New Zealanders $(\mathrm{Q} 9(\mathrm{H}))$. This viewpoint was reiterated in the comments with one respondent stating, 'as a New Zealander we should have a right to freedom camp', while another said 'freedom camping as a New Zealander should be our right as long as people respect and do not trash the place'. However, some felt that this inherent right has ceased to apply given the current climate of tourism in New Zealand, regarding both the volume of tourists and the level of respect tourists show, 'yes freedom camping was once a right of all New Zealanders, unfortunately times change and now it's no longer the case'.

There was no clear consensus as to whether the benefits of freedom camping outweigh the negatives for the Taupō District (Q9(C)), with residents producing very neutral responses on the matter. The inconclusive view is exemplified by a respondent who stated, 'the misuse of it needs to be monitored and enforced more closely to maximise the benefits that can come from it as it is not all negative as most people think'.

Tourism research shows that the industry has a positive impact on the destination image of a location (Tosun, 2002). Evidently, the host community had mixed opinions on freedom camping's impact on Taupō Districts destination image, with the overall result suggesting that it is somewhat worsened by freedom camping. Interestingly, it was those directly employed in tourism who viewed freedom camping's impact on the destination image most negatively (see Table 4.10). This perception of worsened destination image may be tied back to the way freedom camping has been negatively portrayed in the media, especially in contrast with other forms of tourism in Taupō District, such as the large luxury tourism segment.

The host community's desired number of freedom campers was compared to their desired number of tourists to gain insights into how the level of support differed between the two. Unsurprisingly, the consensus was that the desired number of tourists is higher than the desired number of freedom campers (see Table 4.11). This result can be linked back to SET and how the host community do not appear to perceive benefits from freedom camping, but do from tourism. While respondents largely felt that the current number of freedom campers is appropriate, there were more who felt this number should decrease than those who felt it should increase. Those directly employed in tourism, once again, had the most negative outlook. Conversely, it was mostly agreed that the number of tourists in the Taupō District should increase, with those directly employed in tourism having the highest level of agreement.

The varying levels of support for freedom camping reflect the need to improve how freedom camping operates in the Taupō District to maximise the benefits of it, and to ensure 
the host community do not build animosity towards it, which could lead to tourism losing its social license to operate.

\subsection{Implications and Recommendations}

There are several implications and recommendations that are presented based on the research findings. The recommendations are predominately directed at the public sector, namely local council and the Government, as they have the ability to mitigate the negative impacts of freedom camping and help expand and capitalise on the benefits of it.

The findings of this study reinforce the need for more management and better facilities at freedom camping sites. It was apparent that residents are not happy paying for facilities and infrastructure that they do not feel benefit them. Overall, they would like the freedom camping sites to contain adequate facilities in order to mitigate the negative impacts that rubbish and waste can have when not managed properly. As stated in Section 2.3.3, within the last couple of years the Government and Taupō District Council have introduced initiatives to better manage freedom camping (MBIE, 2019 ; TIA, 2019 ). While initiatives such as more toilets and wash facilities, freedom camping ambassadors, and the AI solar-powered cameras, have recently been introduced at Hipapatua Reserve/Reid's Farm (Marshall, 2019), these have not been established more widely. The Taupō District Council could look to implement initiatives such as these at the other non-self-contained freedom camping sites in the district, namely Mangakino Recreation Reserve, Whakamaru Domain, and Whakamaru Recreation Reserve. This would ensure that all sites have the same necessary facilities, and the same benefits to freedom campers staying in those locations.

The Freedom Camping Act 2011 (FCA) was introduced in response to the need for regulating freedom camping in New Zealand while the country hosted the Rugby World Cup that year (September-October 2011). Since the World Cup ended, regions such as the Taupō District have taken the initiative to create their own bylaws to further manage freedom camping. However, rather than relying on local councils setting bylaws that differ across the country, the FCA could be revisited to ensure it still is suitable for the current climate of freedom camping, given the increasing popularity and expansion of freedom camping areas. Furthermore, the Government need to take residents' perceptions and attitudes towards freedom camping into consideration as, if they continue to promote freedom camping without addressing concerns, they risk tourism losing its social license to operate across different locations in New Zealand. 
Another initiative that the Government could implement to improve the image and perception of freedom camping in New Zealand is to shift from the title of 'freedom camping' to 'responsible freedom camping', or 'simply responsible camping', to align with the Responsible Camping Forum and the Responsible Camping Working Group, both of which are responsible for managing freedom camping in New Zealand. The name shift would not only create cohesion between the activity and the current stakeholder initiatives in place, but would also help to combat the negative connotations that come with the title of 'freedom camping'.

Additionally, one of the main suggestions by respondents in their comments was that freedom camping should no longer be 'free'. Rather, those participating should have to contribute a small fee or levy to help fund the maintenance of the sites which they use. Whilst there is a Freedom Camping Fund that is dedicated to issues such as toilets and waste (MBIE, $2019^{\mathrm{b}}$ ), it seems that spread across 16 regions of New Zealand, the financial contribution is not enough to negate these problems and does not make a noticeable difference to residents. Introducing an affordable levy for freedom campers would help to change the common perception that freedom camping is a form of freeloading (Collins et al., 2018) and does not contribute to the local economy. Furthermore, a levy would also reduce the strain on Government funding. The need for the introduction of a freedom camping levy is consistent with findings from Schott (2018), where both freedom campers and residents thought this would be an effective way to manage freedom camping. It is recommended that if a levy is introduced it is restricted to international freedom campers only. This is because the activity of freedom camping is an established form of recreation in New Zealand and is considered by many New Zealanders to be a right for them, as they contribute to its operation through taxes and rates. A levy for international freedom campers would also be consistent with other differential pricing schemes in tourism in New Zealand where international visitors are charged more than locals.

Looking towards the future, freedom camping sites should be purpose built and not impose on existing recreational sites. Having designated freedom camping spaces would help to avoid the conflicts that arise when sites are used for several competing activities. Further, these designated freedom camping spaces could be funded by the proposed freedom camping levy.

Additionally, freedom campers themselves can mitigate some of these negatively perceived impacts through monitoring their behaviour at sites. It is imperative that freedom 
campers are aware of and educated on best practice behaviours. As discussed in Section 2.3.3, educational campaigns and ambassador programmes have been a focus of freedom camping funding in recent years (Cropp, 2019). In addition to this, Taupō District Council should ensure that all freedom camping sites have codes of conduct and clear instructions about restrictions signposted. Further, vehicle rental companies should give visitors hiring self-contained vehicles a briefing on freedom camping expectations in New Zealand.

This study also presents numerous implications for academia regarding future research opportunities, which will be addressed in Chapter Six.

\subsection{Summary}

Chapter Five, guided by the research objectives, discussed the findings of the study, evaluated the overall support of freedom camping by the host community, and presented various implications for managing the perceived impacts of freedom camping. It also identified the key concerns relating to freedom camping and found that the host community's employment relationship with tourism did not significantly impact on their perceptions. 


\section{CHAPTER SIX: CONCLUSION}

\subsection{Introduction}

In this chapter, the key findings of the research are synthesised, and the study's contributions to literature and stakeholders are discussed. Following this, the limitations of the research are addressed and suggestions for avenues of future research conferred.

\subsection{Key Research Findings}

The Taupō District, New Zealand, is reliant on its tourism industry for economic stability. To maintain a successful tourism industry in a destination, it is vital to appreciate the host community's perceptions and preferences regarding tourism (Haywood 1986; Lankford, 1994). This study adopted and applied these principles in the context of freedom camping. The purpose of this study was to establish what the host community's perceptions of freedom camping impacts are, how these perceptions differ across employment groups using social exchange theory (SET), and gauge the host community's overall support of freedom camping in the Taupō District. As discussed in Section 2.6, SET suggests that a group will willingly become involved in an exchange with another party if they think that there will be a benefit from it (Gursoy \& Kendall, 2006). In the context of this research, SET suggested that those who are employed in tourism will have more positive perceptions of freedom camping impacts than those who are not, as they are assumed to benefit financially from it.

The first objective of the study was to determine how the host community of the Taupō District perceives the impacts of freedom camping. The study found that the host community had mixed views on freedom camping's impacts. The main concern for the host community was identified as being the detrimental environmental impacts that freedom camping can cause. Litter was noted as the most common complaint, followed by freedom camping putting pressure on public facilities and infrastructure. These concerns were also prevalent throughout the tourism impact literature examined (Andereck et al, 2005; Brunt \& Courtney, 1999; Dogan, 1989; Johnson et al., 1994; Lankford, 1994; Liu \& Var, 1986; McCool \& Martin, 1994; Okech, 2010; Sheldon \& Var, 1984). Unlike the tourism literature examined in Section 2.6.3, which found the economic impacts to be viewed most positively (Andereck et al., 2005; Tosun, 2002), the findings of this study suggest the positive economic contribution of freedom camping is largely not recognised by the host community of the Taupō District. Many respondents felt that freedom camping had few financial benefits for them, particularly when considering their own personal income and employment opportunities. Rather, there was agreement amongst many 
respondents that freedom camping is a form of freeloading, which is consistent with freedom camping literature (Collins et al., 2018).

The second research objective was to use SET to examine how perceptions of freedom camping impacts differ depending on the host community members' employment relationship with the tourism industry (Andereck \& McGehee, 2008; Andriotis, 2005). To accomplish this, the host community was grouped into those directly employed in tourism, those indirectly employed in tourism, those whose employment has no relation to tourism, and those not in employment. Findings deduced that there was no significant difference between host community perceptions based on their employment relationship with tourism. It was conjectured that this is due to freedom camping being a complex activity to define, and that its benefits are not as straight forward as those of the tourism industry. Further, those directly employed in tourism encompassed host community members working in the accommodation sector, who are in direct competition with freedom camping. Additionally, it is acknowledged that the negative portrayal of freedom camping in the media (Kirkeby, 2016; McMichael, 2017; Shand, 2016 ${ }^{\mathrm{a}}, 2016^{\mathrm{b}}$ ) may have had a significant impact in shaping people's perceptions, along with word of mouth from family and friends, as not all respondents have had first-hand experiences with freedom camping or freedom campers. Therefore, this suggests that SET may not be the most suitable theory to adopt when looking at the relationship between the host community and freedom camping impacts.

The final research object was to evaluate the host community's overall support for the freedom camping industry. The findings suggest that the freedom camping industry is largely supported by the host community of the Taupō District, however, this support is conditional, and therefore changes need to be made so that the positive perceptions of freedom camping impacts outweigh the negatives. The majority of the host community felt that the Government could do more to control freedom camping's impact on the ecological environment. They also supported the idea of introducing a levy to help fund the maintenance of freedom camping facilities. Thus, highlighting the importance of cooperation between stakeholder groups in a destination, to ensure the host community continue to support tourism and its social license to operate is maintained (Robson \& Robson, 1996).

\subsection{Contributions}

By fulfilling the objectives of the research, the study has contributed to tourism literature, literature on the activity of freedom camping, and further produced valuable findings 
to support the management of the activity of freedom camping. Firstly, this study is the first in tourism literature to examine the host community perceptions of freedom camping impacts. It has identified the key perceived impacts that freedom camping has on a destination, according to the host community. Secondly, it is the first study in freedom camping literature to apply SET to examine how perceptions differ across the host community by dividing the population into four groups based on their employment relationship with tourism. This study has determined that SET did not apply in this context, and employment in tourism did not influence the host community's perceptions of freedom camping impacts. This result contrasted with tourism literature, which finds those employed in the industry have the most positive perceptions. This study has also contextualised these findings within the Taupō District of New Zealand. Thus, the research has filled the literature gap identified of investigating host community perceptions of freedom camping impacts using a SET perspective. As discussed in Section 5.5, the study also contributed research applications for local council and the Government to support decision making for the management of freedom camping, and to mitigate the negative impacts and perceptions.

\subsection{Future Research Opportunities}

Through this research, limitations have been identified and recognised as avenues for future research in the subject area of freedom camping.

As discussed in Section 3.8, there were limitations that arose from the methodology employed in the study. These were largely related to the sample population and surveying method, such as the distribution of respondents across the groups, voluntary bias, overall sample size, and geographical locations of data collection.

In this research, the perceived cultural impacts from both tourism and freedom camping have been integrated into the social impacts in the literature review and the survey. A result of this was a lack of focus on cultural elements. Future research should look to include perceived cultural impacts as its own section of surveying to develop a greater understanding of the relationship between freedom camping and a destination's culture.

The survey did not distinguish between freedom campers who were non-self-contained and those using self-contained vehicles, as both fall under the scope of freedom camping. This distinction may have led to different results as many respondents found lack of facilities to be a deciding factor in their perception of the impacts and support for freedom camping. This was 
illustrated by one respondent who stated, 'first people need to realise the difference between freedom campers that are sleeping in the back of a car or tent and littering/toileting on the ground and self-contained campers that take rubbish with them and leave areas clean and tidy'. Thus, future research could look to compare between these two variants of freedom camping.

In the current research, the data collection was conducted from late November to early December, at the beginning of the peak summer tourism season. This meant that the impacts of freedom camping on the destination may not have been as evident to the respondents at the time. Had the survey been undertaken at the end of the peak tourism season, the results may have been more polarising. Further, previous studies show that host communities' perceptions of tourism impacts are not constant, and they can fluctuate continuously between the negative and the positive (Pizam, 1978). As this same principle is likely to apply to the activity of freedom camping it is recommended that future studies could adopt a longitudinal approach to test for differences in host community perceptions across different visitor seasons, for example, comparing between summer and winter.

This research was underpinned by SET and focused on four different groups based on their employment relationship with the tourism industry. As discussed, those employed in tourism do not universally benefit from freedom camping. Future studies could therefore test SET using differently defined groups. Researchers could focus solely on those directly employed in tourism, and test for differences in perception based on the varying sectors within the tourism industry, such as accommodation, transport, attractions and activities. Additionally, it is recognised that the study only examined the host community's employment relationship with tourism at the time of the survey and did not account for the possibility of people having previously worked in the sector or people wanting to work in the tourism sector in the future, as this could also have an influence on their perceptions. Thus, future research could also look to distinguish between past employment and aspirational employment when creating distinct groups to compare. Alternatively, SET could be integrated with stakeholder theory, and researchers could test for differences in perceptions between tourism stakeholder groups, such as the public sector and private sector, as well as the host community. Further, as freedom campers themselves are considered a critical stakeholder group in the management of freedom camping (Schott, 2018) future researchers could explicitly compare those in the host community who freedom camp and those who do not. 
Following on from the public petitions discussed in Section 2.3.4, it will be important to monitor the impact that the COVID-19 pandemic has on the future of freedom camping in New Zealand. As the tourism industry rebuilds, researchers can examine how the Government responds to public conversation surrounding COVID-19 and freedom camping; whether they decide to restrict it further or promote it. Additionally, future research can explore COVID19's impact on freedom camping demand. With New Zealand households facing increasing financial pressures and international travel restrictions in place as a result of the pandemic, there may be an increase in domestic tourists wanting to engage in freedom camping as a lowcost accommodation alternative.

\subsection{Final Comments}

The findings presented in this study explore the perceived impacts of freedom camping in the Taupō District, according to the host community. Recommendations for future research examining the activity of freedom camping are discussed. Additionally, findings provide insights that have practical value for local council and the Government in addressing potential negative impacts from the activity of freedom camping to ensure that the host community is satisfied, and tourism maintains its social licence to operate in Taupō District. 


\section{REFERENCES}

Aas, C., Ladkin, A. \& Fletcher, J. (2005). Stakeholder collaborations and heritage management. Annals of Tourism Research, 32(1), 28-48.

Andereck, K. L., Valentine, K. M., Knopf, R. C. \& Vogt, C. A. (2005). Residents‘ perceptions of community tourism impacts. Annals of Tourism Research, 32(4), 1056-1076.

Andriotis, K. (2005). Community Groups' Perceptions of and Preferences for Tourism Development: Evidence from Crete. Journal of Hospitality \& Tourism Research, 29(1), 67-90.

Angus \& Associates (2017). Freedom Camping Literature Review. Retrieved from: https://tia.org.nz/assets/Uploads/cd0023cf72/Freedom-Camping-Literature-ReviewReport-March-2018.pdf [20 Oct 19].

Ap, J. (1992) Residents' Perceptions of Tourism Impacts. Annals of Tourism Research, 19, 665-690.

Bartlett, M. S. (1954). A note on the multiplying factors for various chi square approximation. Journal of Royal Statistical Society, 16(Series B), 296-8.

Boley, B. B., McGehee, N. G., Perdue, R. R. \& Long, P. (2014). Empowerment and resident attitudes toward tourism: Strengthening the theoretical foundation through a Weberian lens. Annals of Tourism Research, 49, 33-50.

Bouma, G. D. \& Ling, R. (2004). The research process. USA: Oxford University Press.

Brooker, E. \& Joppe, M. (2013). Trends in camping and outdoor hospitality - An international review. Journal of Outdoor Recreation and Tourism, 3-4(4), 1-6.

Brunt, P., \& Courtney, P. (1999). Host Perceptions of Sociocultural Impacts. Annals of Tourism Research 26, 493-515.

Budowski, G. (1976). Tourism and Environmental Conservation: Conflict, Coexistence, or Symbiosis? Environmental Conservation, 3(1), 27-31.

Byrd, E. T., Bosley, H. E. \& Dronberger, M. G. (2009). Comparisons of stakeholder perceptions of tourism impacts in rural eastern North Carolina. Tourism Management, 30(5), 693-703.

Caldicott, R., Scherrer, P., \& Jenkins, J. (2014). Freedom camping in Australia: Current status, key stakeholders and political debate. Annals of Leisure Research, 17, 417-442.

Carrig, M. M. \& Hoyle, R. H. (2011). Measurement Choices: Reliability, Validity, and Generalizability. In A. T. Panter \& S. K. Sterba (Eds.), Multivariate applications series. Handbook of Ethics in Quantitative Methodology (pp.127-157). Routledge/Taylor \& Francis Group.

Carroll, J. (2020). Calls to ban freedom camping post-Covid 19. Retrieved from: https://www.stuff.co.nz/travel/news/121414848/calls-to-ban-freedom-campingpostcovid-19 [6 Aug 20]. 
Cattell, R. B. (1966). The scree test for the number of factors. Multivariate Behavioral Research, 1, 245-276.

Collins, D., Kearns, R. (2010). 'Pulling up the Tent Pegs?' The Significance and Changing Status of Coastal Campgrounds in New Zealand. Tourism Geographies, 12(1), 53-76.

Collins, D., Kearns, R., Bates, L. \& Serjeant, E. (2018). Police power and fettered freedom: regulating coastal freedom camping in New Zealand. Social \& Cultural Geography, 19(7), 894-913.

Creswell, J. W. (2014). Research Design: Qualitative, Quantitative, and Mixed Methods Approaches, $4^{\text {th }}$ ed. Thousand Oaks, CA: Sage Publications.

Cronbach, L. J. (1951). Coefficient alpha and the internal structure of tests. Psychometrika, 16(3), 297-334.

Cropp, A. (2019). Another $\$ 8$ million to manage freedom camping. Retrieved from: Stuff.co.nz:https://www.stuff.co.nz/business/112788264/another-8-million-tomanage-freedom-camping [3 Mar 20].

Dann, G., Nash, D., \& Pearce, P. (1988). Methodology in tourism research. Annals of Tourism Research, 15(1), 1-28.

Dare, M. L., Schirmer, J. \& Vanclay, F. (2014). Community engagement and social licence to operate. Impact Assessment and Project Appraisal, 32(3), 188-197.

Denzin, N. K. \& Lincoln Y. S. (2011). The Sage Handbook of Qualitative Research (Ed.). Thousand Oaks, CA: Sage Publications.

Department of Conservation [DoC] (2006). Review of camping opportunities in New Zealand. Heritage Appreciation Unit Research, Development \& Improvement, Department of Conservation.

DoC (2017). Status change to three campsites. Retrieved from: https://www.doc.govt.nz/news/media-releases/2017/status-change-to-three-campsites/ [28 Mar 20].

Department of Internal Affairs [DIA] (2016). Managing Freedom Camping in Public Places. Retrieved from: https://www.lgnz.co.nz/assets/Uploads/d3b76e001c/FreedomCamping-Situational-Analysis-16.12.pdf [20 Mar 20].

Dogan, H. (1989) Forms of Adjustment: Sociocultural Impacts of Tourism. Annals of Tourism Research, 16, 216-236.

Easterby-Smith, M., Thorpe, R., \& Jackson, P. R. (2008). Management Research (3rd ed.). Los Angeles: Sage Publications.

Emerson, R. M. (1976). Social exchange theory. Annual Review of Sociology, 2, 335-362. 
Fieger, P., Prayag, G., Hall, M. C. \& North, C. (2019). The tourism value of international freedom campers to New Zealand. Tourism Recreation Research, 1-6.

Freedom Camping Act 2011.

Graefe, D. A., \& Dawson, C. P. (2013). Rooted in place: Understanding camper substitution preferences. Leisure Sciences, 35, 365-381.

Guba, E. G. (1990). The alternative paradigm dialog. In E. G. Guba (Ed.), The paradigm dialog (pp. 17-30). Newbury Park, CA: Sage Publications.

Gursoy, D. and Kendall, K. (2006), Hosting mega events: modelling locals' support. Annals of Tourism Research, 33(3), 603-623.

Hadia, NU., Abdullaha, N. \& Sentosa, I. (2016). An Easy Approach to Exploratory Factor Analysis: Marketing Perspective. Journal of Educational and Social Research, 6(1), 215-223.

Hammond, D. (2016). Freedom camping: Who should pay? Local Government Magazine.

Haralambopoulos, N., and Pizam, A. (1996). Perceived Impacts of Tourism: The Case of Samos. Annals of Tourism Research, 23, 503-526.

Hardy, A., Wickham, M. \& Gretzel, U. (2013). Neglected Stakeholder Groups: Conceptualising a Dynamic Model for Neglected Stakeholder Analysis and Engagement. Corporate Ownership and Control, 11(1), 348-359.

Haywood, K. M. (1988). Responsible and responsive tourism planning in the community. Tourism Management, 9(2), 105-118.

Homans, G. C. (1958). Social Behavior as Exchange. American Journal of Sociology, 63(6), 597-606.

Jennings, G. (2007). Advances in Tourism Research: Theoretical Paradigms and Accountability. In A. Matias, P. Nijkamp and P. Nero (Eds.), Advances in Modern Tourism Research. Economic Perspectives. (p. 9-35). Physica-Verlag Heidelberg.

Johnson, J., Snepenger, D. \& Akis, S. (1994). Residents' Perceptions of Tourism Development. Annals of Tourism Research, 21, 629-642.

Kaiser, H. F. (1974). An index of factorial simplicity. Psychometrika, 39, 32-36.

Kaushik, V. \& Walsh, C. A. (2019). Pragmatism as a Research Paradigm and Its Implications for Social Work Research. Social Sciences, 8(9), 255-272.

Kavallinis, I. \& Pizam, A. (1994). The Environmental Impacts of Tourism- Whose Responsibility Is It Anyway? The Case Study of Mykonos. Journal of Travel Research, 33(2), 26-32.

Kearns, R., Collins, D. \& Bates, L. (2017). "It's freedom!”: examining the motivations and experiences of coastal freedom campers in New Zealand. Leisure Studies, 36(3), 395408. 
Kirkeby, L. (2016). Bush-pooping freedom campers shock walker. Retrieved from: https://www.stuff.co.nz/environment/87994964/bush-pooping-freedom-campersshock [1 Apr 20].

Kuhn, T. S. (1970). The Structure of Scientific Revolutions, 2nd ed. Chicago: University of Chicago Press.

Kýlýnç, H \& Fırat, M. (2017). Opinions of Expert Academicians on Online Data Collection and Voluntary Participation in Social Sciences Research. Kuram ve Uygulamada Egitim Bilimler, 17(5), 1461-1486.

Lankford, S. V. (1994). Attitudes and Perceptions Towards Tourism and Rural Regional Development. Journal of Tourism Research, 35-43.

Lankford, S. V., \& Howard, D. R. (1994). Developing a tourism impact attitude scale. Annals of Tourism Research, 21, 121-139.

Lemm, K. M. (2012). Stratified Sampling. In N. J. Salkind (Eds.), Encyclopaedia of Research Design (pp. 1452-1454). Thousand Oaks, CA: SAGE Publications.

Lincoln, Y., Lynham, S. A. \& Guba, E. G. (2011). Paradigms and perspectives in contention. In N. K. Denzin \& Y. S. Lincoln (Ed.), The Sage Handbook of Qualitative Research (pp. 91-95). Thousand Oaks, CA: Sage Publications.

Liu, J. C. \& Var, T. (1986). Resident attitudes toward tourism impacts in Hawaii. Annals of Tourism Research, 13, 193-214.

Liu, J. C., Sheldon, P. J. \& Var, T. (1987). Resident Perception of The Environmental Impacts of Tourism. Annals of Tourism Research, 14, 17-37.

Marshall, C. (2019). Campground AI camera on the way for Taupō Reid's Farm. Retrieved from: https://www.stuff.co.nz/travel/news/117917896/campground-ai-camera-on-theway-for-taup-reids-farm [20 Jul 20].

Maxwell, J. A. (2012). Qualitative research design: An interactive approach. Thousand Oaks, CA: Sage Publications.

McCool, S., \& Martin. S. (1994). Community Attachment and Attitudes Towards Tourism Development. Journal of Travel Research 32(3), 29-34.

McMichael, L. (2017). Freedom campers banned from three Taupō reserves. Retrieved from: https://www.nzherald.co.nz/rotorua-dailypost/news/article.cfm?c_id=15034o38\&objectid=11950487 [30 Mar 20].

Merton, R. K. (1968). Social Theory and Social Structure. New York, NY: The Free Press.

Messick, S. (1989). Validity. In R. L. Linn (Ed.), The American Council on Education/Macmillan series on higher education. Educational measurement (p.13103). Macmillan Publishing Co, Inc; American Council on Education.

Ministry of Business, Innovation \& Employment [MBIE] (2018). Terms of reference for the freedom camping working group. https://www.mbie.govt.nz/dmsdocument/1239freedom-camping-working-group-terms-of-reference-pdf [20 Feb 20].

MBIE (2019) $)^{\text {a }}$ Freedom camping by international visitors in New Zealand. Retrieved from: https://www.mbie.govt.nz/immigration-and-tourism/tourism-research-and- 
data/tourism-data-releases/international-visitor-survey-ivs/international-visitorsurvey-analysis-and-research/freedom-camping-by-international-visitors-in-newzealand/ [20 Aug 19].

MBIE (2019) ${ }^{\mathrm{b}}$ Responsible Camping. Retrieved from: https://www.mbie.govt.nz/immigration-and-tourism/tourism/tourismprojects/responsible-camping/ [12 Mar 20].

MBIE (2020). How the IVL works. Retrieved from: https://www.mbie.govt.nz/immigrationand-tourism/tourism/tourism-funding/international-visitor-conservation-and-tourismlevy/how-the-ivl-works/ [12 Aug 20].

Nemoto, T., \& Beglar, D. (2014). Likert-scale questionnaires. In JALT 2013 Conference Proceedings, 1-8.

Nunkoo, R \& Gursoy, D. (2012). Residents' Support for Tourism: An Identity Perspective. Annals of Tourism Research, 39(1), 243-268.

Nunkoo, R., Smith, S. L. J., \& Ramkissoon, H. (2013). Residents' attitudes to tourism: A longitudinal study of 140 articles from 1984 to 2010. Journal of Sustainable Tourism, $21(1), 5-25$.

Okech, R. N. (2010). Tourism Impacts on Local Communities Around Costal Zones: Issues of Sustainable Development. Journal of Tourism Challenges and Trends, 3(1), 189-120.

Patton, M. Q. (2002). Qualitative Research and Evaluation Methods, 3rd ed. Thousand Oaks, CA: Sage Publications.

Pearce, D. G. (2012). Frameworks for Tourism Research. Wallingford, Oxfordshire; Cambridge, MA: CABI.

Perdue, R. R., Long, P. T. \& Allen, L. (1987). Rural Resident Tourism Perceptions and Attitudes. Annals of Tourism Research, 14(3), 420-429.

Phillips, D. C., \& Burbules, N. C. (2000). Postpositivism and educational research. Lanham, MD: Rowman \& Littlefield.

Pizam, A. (1978). Tourism's Impacts: The Social Costs to the Destination Community as Perceived by its Residents. Journal of Travel Research, 16(4), 8-12.

Puczkó, L. \& Rátz, T (2000). Tourist and Resident Perceptions of the Physical Impacts of Tourism at Lake Balaton, Hungary: Issues for Sustainable Tourism Management. Journal of Sustainable Tourism, 8(6), 458-478.

Radio New Zealand (2019). Artificial intelligence, solar powered cameras for new responsible camping scheme. https://www.rnz.co.nz/news/national/404661/artificial-intelligencesolar-powered-cameras-for-new-responsible-camping-scheme [26 February 2020].

Regional Tourism New Zealand (2020). Destinations. Retrieved from: https://rtnz.org.nz/destinations\# [28 Mar 20]. 
Robson, J. \& Robson, I. (1996). From shareholders to stakeholders: Critical issues for tourism marketers. Tourism Management, 17(7), 533-540.

Ryan, C. (2002). Equity, management, power sharing and sustainability - issues of the "new tourism'. Tourism Management, 23, 17-26.

Shand, M. (2016) ${ }^{\mathrm{a}}$. Freedom campers could be banned in Taupō. Retrieved from: https://www.stuff.co.nz/travel/travel-troubles/77005051/freedom-campers-could-bebanned-in-taupo?rm=m [2 Apr 20].

Shand, M. (2016) ${ }^{\mathrm{b}}$. Reid's Farm could close due to complaints. Retrieved from: https://www.stuff.co.nz/national/80391585/reids-farm-could-close-due-to-complaints [1 Apr 20].

Shand, M. (2016) ${ }^{\mathrm{c}}$. Last day for Reid's Farm camping. Retrieved from: https://www.stuff.co.nz/waikato-times/news/taupo-times/80819541/last-day-for-reidsfarm-camping [1 Apr 20].

Shand, M. (2017). Turangi picks its ideal freedom campers. Retrieved from: https://www.stuff.co.nz/waikato-times/news/taupo-times/90453695/turangi-picks-itsideal-freedom-campers [30 Mar 20].

Sheldon, P. \& Var, T. (1984). Resident Attitudes to Tourism in North Wales. Tourism Management 5(1), 40-47.

Sinclair-Maragh, G. \& Gursoy, D. (2015). Imperialism and tourism: The case of developing island countries. Annals of Tourism Research, 50, 143-158.

Smallman, C. \& Moore, K. (2010). Process Studies of Tourist' Decision Making. Annals of Tourism Research, 37(2), 397-422.

Smith, S. J. L. (1995). Tourism Analysis: A Handbook. Harlow: Longman.

Stats NZ (2018). Taupō District. https://www.stats.govt.nz/tools/2018-census-placesummaries/taupo-district\#population-and-dwellings [30 Apr 19].

Stats NZ (2020). International travel: January 2020. Retrieved from: https://www.stats.govt.nz/tereo/information-releases/international-travel-january-2020 [25 Mar 20].

Steven, R. (2017). Mangakino keen for more campers. Retrieved from: https://www.stuff.co.nz/waikato-times/92723992/mangakino-keen-for-more-campers [31 Mar 20].

Steven, R. (2018). Taupō District Council says freedom camping bylaw is working. Retrieved from: https://www.stuff.co.nz/travel/101671787/taupo-district-council-says-freedomcamping-bylaw-is-working [2 Apr 20].

Straub, D., Boudreau, M. C., Gefen, D. (2004). Validation Guidelines for IS Positivist Research. Communications of the Association for Information Systems, 13, 380-427. 
Stuff (2020). Petition seeking freedom camping ban withdrawn after organiser is threatened. Retrieved from: https://www.stuff.co.nz/travel/news/121466053/petition-seekingfreedom-camping-ban-withdrawn-after-organiser-is-threatened [7 Aug 20].

Swarbrooke, J. (1999). Sustainable tourism Management. Oxford, NY: CABI Pub.

Taupō District Council. (2017). Freedom Camping Bylaw 2017. Retrieved from: https://www.taupodc.govt.nz/repository/libraries/id:25026fn3317q9slqygym/hierarch y/our-council/policies-plans-andbylaws/bylaws/documents/Freedom\%20Camping\%20Bylaw\%202017.pdf [15 Dec 19].

Taupō District Council. (2020) $)^{\mathrm{a}}$. About Our District. Retrieved from: https://www.taupodc.govt.nz/community/about-our-district [20 Feb 20].

Taupō District Council. (2020) ${ }^{\mathrm{b}}$. Three council freedom camping areas now closed. Retrieved from: https://www.taupodc.govt.nz/council/news?item=id:29erix2ok1cxbygxvh86 [22 Jun 20].

Tosun, C. (2002). Host Perceptions of Impacts: A comparative tourism study. Annals of Tourism Research, 29(1), 231-253.

Tourism Industry Aotearoa [TIA] (2019) . Tourism by the Numbers. Retrieved from: https://tia.org.nz/about-the-industry/quick-facts-and-Figures/ [20 Mar 20].

TIA (2019) ${ }^{\mathrm{b}}$. Responsible Camping. Retrieved from: https://tia.org.nz/advocacy/tiaprojects/responsible-camping/ [12 Nov 19].

Tourism New Zealand (2019). About the tourism industry. Retrieved from: https://www.tourismnewzealand.com/about/about-the-tourism-industy/ [20 Dec 19].

Vincent, V. C. \& Thompson, W. (2002). Assessing community support and sustainability for ecotourism development. Journal of Travel Research, 41(2), 153-160.

Watson, M. (2012). Taupō wants freedom campers away from lake, town. Retrieved from: http://www.stuff.co.nz/dominion-post/news/6808215/Taupo-wants-freedom-campersaway-from-lake-town [1 Apr 20].

Zmyślony, P., Kowalczyk-Anioł, J. \& Dembińska, M. (2020). Deconstructing the Overtourism-Related Social Conflicts. Sustainability, 12(4), 1695-1721. 
APPENDICES 
APPENDIX A: Media Articles

\begin{tabular}{|c|c|c|c|c|c|}
\hline Author & Date & Title & Source & Stance & Content of The Article \\
\hline Watson, M. & April 2012 & $\begin{array}{l}\text { Taupō wants freedom } \\
\text { campers away from } \\
\text { lake, town }\end{array}$ & $\begin{array}{l}\text { Dominion Post, } \\
\text { Stuff.co.nz }\end{array}$ & Mixed & $\begin{array}{l}\text { In } 2012 \text { the Ferry Road freedom camping site, which was restricted to self-contained } \\
\text { vehicles and located in central Taupō beside the lake, had been attracting non-self- } \\
\text { contained freedom campers such as those using cars, vans, and tents. Commercial } \\
\text { operators had taken photographic evidence of non-approved vehicles at the site, as well } \\
\text { as campers bathing naked and urinating in the lake. At the time of the article, there } \\
\text { were } 1500 \text { designated campsites in Taupō, and commercial operators were struggling } \\
\text { to compete with the freedom camping sites, with holiday parks reportedly losing } \\
\$ 165,000(15 \%) \text { revenue between November } 2011 \text { and January } 2012 \text {. Conversely, the } \\
\text { NZMCA supported the site and a survey showed that each camper spent an average of } \\
\$ 400 \text { in the town. }\end{array}$ \\
\hline Shand, M. ${ }^{\mathrm{a}}$ & $\begin{array}{l}\text { February } \\
2016\end{array}$ & $\begin{array}{l}\text { Freedom campers } \\
\text { could be banned in } \\
\text { Taupō }\end{array}$ & Stuff.co.nz & Negative & $\begin{array}{l}\text { In February } 2016 \text { freedom camping was at risk of being banned in Taupō, after campers } \\
\text { angered residents and councillors by defecating in reserves and washing their clothes } \\
\text { in local swimming pools. Tension with freedom campers was also growing in Turangi, } \\
\text { where campers had inhabited a non-residential cul-de-sac and spread their belongings } \\
\text { over the road. Councillor, Dean Cozens, said this type of occurrence was becoming } \\
\text { more prevalent in the area. }\end{array}$ \\
\hline Shand, M. ${ }^{\mathrm{b}}$ & May 2016 & $\begin{array}{l}\text { Reid's Farm could } \\
\text { close due to } \\
\text { complaints }\end{array}$ & Stuff.co.nz & Negative & $\begin{array}{l}\text { In May } 2016 \text { Hipapatua/Reid's Farm Recreation Reserve, which is Taupō's most } \\
\text { popular designated freedom camping spot, was announced as being at risk of closure } \\
\text { due to complaints about the freedom campers. Between September } 2014 \text { and May } \\
2016 \text {, the Taupō District Council had received } 69 \text { complaints about freedom camping. } \\
\text { Eleven of the complaints were about Reid's Farm, making it the only site to have } \\
\text { repeated complaints made against it. Additionally, the police also had concerns about } \\
\text { the site, saying it was a danger to people's health and safety as well as being a drain } \\
\text { on their resources. Between December } 2015 \text { and January } 2016 \text {, the police had } \\
\text { reportedly responded to } 10 \text { serious offences at the reserve, including assaults, burglary } \\
\text { and discharging a firearm. }\end{array}$ \\
\hline
\end{tabular}




\begin{tabular}{|c|c|c|c|c|c|}
\hline Author & Date & Title & Source & Stance & Content of The Article \\
\hline Shand, M. ${ }^{c}$ & June 2016 & $\begin{array}{l}\text { Last day for Reid's } \\
\text { Farm camping }\end{array}$ & $\begin{array}{l}\text { Taupō Times, } \\
\text { Waikato Times, } \\
\text { Stuff.co.nz }\end{array}$ & Neutral & $\begin{array}{l}\text { From June } 2016 \text { until October } 2016 \text {, Reid's Farm was closed for freedom camping. } \\
\text { The closure was to allow the council to carry out any maintenance required at the site } \\
\text { and the reverse remained open for day visitors. }\end{array}$ \\
\hline Kirkeby, L. & $\begin{array}{l}\text { December } \\
2016\end{array}$ & $\begin{array}{l}\text { Bush-pooping } \\
\text { freedom campers } \\
\text { shock walker }\end{array}$ & Stuff.co.nz & Negative & $\begin{array}{l}\text { A resident complained of finding piles of used toilet paper and human waste along the } \\
\text { Redwoods Bike Track opposite Reid's Farm }\end{array}$ \\
\hline Shand, M. & $\begin{array}{l}\text { March } \\
2017\end{array}$ & $\begin{array}{l}\text { Turangi picks its } \\
\text { ideal freedom } \\
\text { campers }\end{array}$ & $\begin{array}{l}\text { Taupō Times, } \\
\text { Waikato Times, } \\
\text { Stuff.co.nz }\end{array}$ & Mixed & $\begin{array}{l}\text { The Turangi Tongariro Community Board expressed their frustration with freedom } \\
\text { campers, particularly those in non-self-contained vehicles. Board member Tangouni } \\
\text { Kingi explained they want freedom campers who are members of the NZMCA and do } \\
\text { not want freedom campers who buy a cheap car and drive around the country 'drying } \\
\text { their undies out the window'. There had also been reports made of freedom campers } \\
\text { assembling washing lines in carparks along with using Turangi's public facilities to do } \\
\text { their laundry. }\end{array}$ \\
\hline Steven, R. & May 2017 & $\begin{array}{l}\text { Mangakino keen for } \\
\text { more campers }\end{array}$ & $\begin{array}{l}\text { Taupō Times, } \\
\text { Waikato Times, } \\
\text { Stuff.co.nz }\end{array}$ & Positive & $\begin{array}{l}\text { Mangakino expressed its support of freedom camping, with councillor Kirsty Trueman } \\
\text { stating the town welcomes campervan visitors. The town was proposing six new } \\
\text { freedom camping sites, five of which would have a public toilet nearby and only one } \\
\text { of which would be restricted to self-contained vehicles. Trueman said that she was } \\
\text { unaware of any negative impacts from the campers and instead felt that they added to } \\
\text { the vibrancy of the waterfront. }\end{array}$ \\
\hline
\end{tabular}




\begin{tabular}{|c|c|c|c|c|c|}
\hline Author & Date & Title & Source & Stance & Content of The Article \\
\hline $\begin{array}{l}\text { McMichael, } \\
\text { L. }\end{array}$ & $\begin{array}{l}\text { November } \\
2017\end{array}$ & $\begin{array}{l}\text { Freedom campers } \\
\text { banned from three } \\
\text { Taupō reserves }\end{array}$ & $\begin{array}{l}\text { Rotorua Daily } \\
\text { Post, NZ Herald }\end{array}$ & Negative & $\begin{array}{l}\text { Complaints of human excrement, used sanitary items, toilet paper and general rubbish } \\
\text { being left by campers, as well as campers using the streams to wash both themselves } \\
\text { and their clothes. The issues are thought to come from non-self-contained 'sliding } \\
\text { door' van campers and not the NZMCA members, who are generally believed to take } \\
\text { good care of the reserve. According to the author during the freedom camping bylaw } \\
\text { hearings, residents from the towns of Omori and Kuratau specifically requested that } \\
\text { the Taupō District Council ensure freedom camping, both self-contained and non-self- } \\
\text { contained, remains prohibited on all council reserves in their townships at the southern } \\
\text { end of Lake Taupō. }\end{array}$ \\
\hline DoC & $\begin{array}{l}\text { December } \\
2017\end{array}$ & $\begin{array}{l}\text { Status change to three } \\
\text { campsites }\end{array}$ & $\begin{array}{l}\text { DoC Media } \\
\text { Release }\end{array}$ & Neutral & $\begin{array}{l}\text { December } 2017 \text { saw the closure of three DoC freedom camping areas in the Taupō } \\
\text { District. The Omori Stream carpark, Oruatua picnic site and the Land Reverse/Taupo } \\
\text { Boat Harbour had previously been restricted areas, which allowed self-contained } \\
\text { camping, however these all changed to become prohibited sites. }\end{array}$ \\
\hline Steven, R. & $\begin{array}{l}\text { February } \\
2018\end{array}$ & $\begin{array}{l}\text { Taupō District } \\
\text { Council says freedom } \\
\text { camping bylaw is } \\
\text { working }\end{array}$ & Stuff.co.nz & Positive & $\begin{array}{l}\text { Between } 1^{\text {st }} \text { December } 2017 \text { and } 23^{\text {rd }} \text { February } 2018 \text { there were } 75 \text { fines issued for } \\
\text { campers who broke the Taupo District's Freedom Camping Bylaw. According to the } \\
\text { council communication manager the Bylaw was working and had effectively reduced } \\
\text { the community's concern. Additionally, it was reported that most freedom campers } \\
\text { were happy to comply with the new rules. }\end{array}$ \\
\hline Marshall, C. & $\begin{array}{l}\text { December } \\
2019\end{array}$ & $\begin{array}{l}\text { Campground AI } \\
\text { camera on the way } \\
\text { for Taupō Reid's } \\
\text { Farm. }\end{array}$ & Stuff.co.nz & Positive & $\begin{array}{l}\text { Tourism Minister Kelvin Davis announced that Hipapatua Reserve (Reid's Farm) will } \\
\text { be included in an expanded pilot for artificially intelligent (AI) solar-powered cameras } \\
\text { that are being used to help manage overcrowding at freedom camping sites through the } \\
\text { CamperMate App. The cameras are also hoped to encourage good behaviour at the site. }\end{array}$ \\
\hline $\begin{array}{l}\text { Taupō } \\
\text { District } \\
\text { Council }^{\mathrm{b}}\end{array}$ & $\begin{array}{l}\text { March } \\
2020\end{array}$ & $\begin{array}{l}\text { Three council } \\
\text { freedom camping } \\
\text { areas now closed }\end{array}$ & $\begin{array}{l}\text { Taupō District } \\
\text { Council }\end{array}$ & Neutral & $\begin{array}{l}\text { In March } 2020 \text { three council run freedom camping sites (Hipapatua / Reid's Farm } \\
\text { Recreation Reserve, Whakamaru Domain and Mangakino Recreation Reserve) were } \\
\text { closed due to Covid-19. All freedom campers were instead encouraged to support local } \\
\text { camping grounds. }\end{array}$ \\
\hline
\end{tabular}




\section{APPENDIX B: Survey Questionnaire}

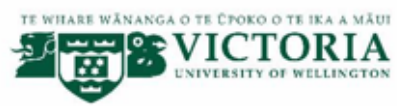

\section{Perceived Impacts of Freedom Camping}

Researcher: Adele Lonergan, School of Management, Victoria University of Wellington

Purpose: I am conducting research on the perceived social, environmental, and economic impacts that the activity of freedom camping has on Taupō District. I value your opinions as a resident of Taupō District and would like to gain a better understanding of your views on freedom camping.

Research Ethics: This research project has received approval by the Pipitea Human Ethics Committee $\# 0000028023$ and is conducted under the following terms:

$>$ You are under no obligation to participate in this research.

$>$ You may withdraw from this research at any point during the questionnaire without providing a reason. You may also withdraw at any time before March $15^{\text {th }}, 2020$ and any information that you have provided will be destroyed.

$>$ Any information you provide may be included in a final report, but responses will only be displayed in aggregated format and personal information such as age and gender is collected for segmentation purposes only.

$>$ The identifiable information you have provided, such as the demographic data provided in sections 1 and 4 , will be destroyed on July $1^{\text {st }}, 2020$.

$>$ Any information you provide will be treated as confidential and only seen by the researcher and the supervisor.

$>$ The information you provide will be stored securely.

Findings will be used for this Master's thesis and may be used for academic publications/presented to conferences/future research projects (e.g. $\mathrm{PhD}$ ).

Human Ethics Committee Information: If you have any concerns about the ethical conduct of the research, you may contact the Victoria University HEC Convenor: Dr Judith Loveridge. Email hec@vuw.ac.nz or telephone +64$4-4636028$

What to do next: It takes approximately 5-10 minutes to complete the questionnaire and your completion of the questionnaire will be understood as agreement with the points outlined above.

$>$ Please turn over to complete the questionnaire. It would help the research if you answered all the questions.

$>$ Please return the questionnaire to the box when completed. If you choose not to participate, please return the uncompleted questionnaire to the box.

Thank you very much for your time and your valuable input.

Best wishes,

Adele Lonergan

You are welcome to retain this cover sheet for your information

\section{Notes:}

- As a thank you for your participation in this questionnaire you can go in the draw to win 1 of $2 \$ 50$ supermarket gift cards. You may choose your preferred supermarket and provide your details for the draw on the final page of the questionnaire.

- If you would like further information about the research, please contact me (lonergadel@myvuw.ac.nz) or my supervisor Dr Christian Schott (christian.schott@vuw.ac.nz). If you would like a summary of the findings, please tick the box provided on the final page of the questionnaire. 


\section{Perceived Impacts of Freedom Camping}

\section{Freedom Camping}

The activity of freedom camping is when a person stays overnight on public land

that is not a recognised camping ground or holiday park without paying a fee.

\section{Taupō District}

Taupō District is situated in the North Island of New Zealand. The district stretches from Mangakino in the northwest to Tongariro National Park in the south, and east into the Kaingaroa Forest (outlined on map).

Section 1: This section focuses on your relationship with Taupo District, freedom camping and tourism.

\section{Q1. Where in Taupō District do you live?}

$\square$ Kinloch

$\square$ Mangakino

$\square$ Taupō Town (please specify which suburb)

$\square$ Turangi

$\square$ Wairakei

$\square$ Waitahanui

$\square$ Other (please specify)

Q2. How long have you been living in Taupō District?
$\square$ Less than 1 year
$\square 11-20$ years
$1-5$ years
$\square 21+$ years
$\square$ 6-10 years

Q3. Have you been freedom camping in the last 10 years?

$\square$ Yes

$\square$ No (please continue to question 5)

Q4. If yes, where did you freedom camp?

$\square$ New Zealand

$\square$ Overseas (please specify)

Q5. What is your employment relationship with tourism?

$\square$ Directly employed in tourism e.g. Tour operator, i-Site staff member, Hotel worker

$\square$ Indirectly employed in tourism e.g. Supermarket worker, Café worker

$\square$ Employment has no relation to tourism e.g. Accountant, Nurse

$\square$ Not in employment

If you are directly employed in tourism, please indicate which sector you belong to

$\square$ Accommodation

$\square$ Attractions and Activities

- Transport

$\square$ Other (please specify) 
Section 2: This section focuses on the perceived social, environmental, and economic impacts that the activity of Freedom Camping has on Taupō District.

Q6. This question focuses on the social impacts of freedom camping on Taupō District.

Please state your level of agreement with each of the following statements by ticking one of the boxes.

\begin{tabular}{|c|c|c|c|c|c|}
\hline $\begin{array}{l}\text { I think freedom } \\
\text { camping... }\end{array}$ & $\begin{array}{l}\text { Disagree } \\
\text { (1) }\end{array}$ & $\begin{array}{l}\text { Somewhat } \\
\text { Disagree } \\
\text { (2) }\end{array}$ & $\begin{array}{l}\text { Neither Agree nor } \\
\text { Disagree } \\
\text { (3) }\end{array}$ & $\begin{array}{l}\text { Somewhat } \\
\text { Agree } \\
\text { (4) }\end{array}$ & $\begin{array}{l}\text { Agree } \\
\text { (5) }\end{array}$ \\
\hline $\begin{array}{l}\text { a) enhances the } \\
\text { community's cultural } \\
\text { identity }\end{array}$ & $\square$ & $\square$ & $\square$ & $\square$ & $\square$ \\
\hline $\begin{array}{l}\text { b) increases the level } \\
\text { of crime in the } \\
\text { community }\end{array}$ & $\square$ & $\square$ & $\square$ & $\square$ & $\square$ \\
\hline $\begin{array}{l}\text { c) causes friction } \\
\text { between the } \\
\text { community and } \\
\text { tourists }\end{array}$ & $\square$ & $\square$ & $\square$ & $\square$ & $\square$ \\
\hline $\begin{array}{l}\text { d) causes congestion } \\
\text { in public spaces }\end{array}$ & $\square$ & $\square$ & $\square$ & $\square$ & $\square$ \\
\hline $\begin{array}{l}\text { e) enables me to } \\
\text { interact with other } \\
\text { cultures }\end{array}$ & $\square$ & $\square$ & $\square$ & $\square$ & $\square$ \\
\hline $\begin{array}{l}\text { f) puts pressure on } \\
\text { public facilities and } \\
\text { infrastructure }\end{array}$ & $\square$ & $\square$ & $\square$ & $\square$ & $\square$ \\
\hline $\begin{array}{l}\text { g) negatively impacts } \\
\text { on my day to day life }\end{array}$ & $\square$ & $\square$ & $\square$ & $\square$ & $\square$ \\
\hline $\begin{array}{l}\text { h) disrupts the peace } \\
\text { and tranquility of } \\
\text { recreational parks }\end{array}$ & $\square$ & $\square$ & $\square$ & $\square$ & $\square$ \\
\hline $\begin{array}{l}\text { i) leads to } \\
\text { overcrowding }\end{array}$ & $\square$ & $\square$ & $\square$ & $\square$ & $\square$ \\
\hline $\begin{array}{l}\text { i) Other (please } \\
\text { specify) }\end{array}$ & $\square$ & $\square$ & $\square$ & $\square$ & $\square$ \\
\hline
\end{tabular}


Q7. This question focuses on the environmental impacts of freedom camping on Taupō District.

Please state your level of agreement with each of the following statements by ticking one of the boxes.

\begin{tabular}{|c|c|c|c|c|c|}
\hline $\begin{array}{l}\text { I think freedom } \\
\text { camping... }\end{array}$ & $\begin{array}{c}\text { Disagree } \\
\text { (1) }\end{array}$ & $\begin{array}{l}\text { Somewhat } \\
\text { Disagree } \\
\text { (2) }\end{array}$ & $\begin{array}{c}\text { Neither Agree nor } \\
\text { Disagree } \\
\text { (3) }\end{array}$ & $\begin{array}{l}\text { Somewhat } \\
\text { Agree } \\
(4) \\
\end{array}$ & $\begin{array}{l}\text { Agree } \\
(5)\end{array}$ \\
\hline $\begin{array}{l}\text { a) negatively impacts } \\
\text { the natural } \\
\text { environment }\end{array}$ & $\square$ & $\square$ & $\square$ & $\square$ & $\square$ \\
\hline \begin{tabular}{l||} 
b) supports the \\
development of \\
public infrastructure
\end{tabular} & $\square$ & $\square$ & $\square$ & $\square$ & $\square$ \\
\hline $\begin{array}{l}\text { c) causes physical } \\
\text { pollution }\end{array}$ & $\square$ & $\square$ & $\square$ & $\square$ & $\square$ \\
\hline $\begin{array}{l}\text { d) causes noise } \\
\text { pollution }\end{array}$ & $\square$ & $\square$ & $\square$ & $\square$ & $\square$ \\
\hline $\begin{array}{l}\text { e) has increased the } \\
\text { amount of litter }\end{array}$ & $\square$ & $\square$ & $\square$ & $\square$ & $\square$ \\
\hline $\begin{array}{l}\text { f) leads to the } \\
\text { destruction of } \\
\text { property }\end{array}$ & $\square$ & $\square$ & $\square$ & $\square$ & $\square$ \\
\hline $\begin{array}{l}\text { g) increases } \\
\text { vandalism }\end{array}$ & $\square$ & $\square$ & $\square$ & $\square$ & $\square$ \\
\hline $\begin{array}{l}\text { h) leads to the } \\
\text { maintenance of } \\
\text { public spaces }\end{array}$ & $\square$ & $\square$ & $\square$ & $\square$ & $\square$ \\
\hline $\begin{array}{l}\text { i) is harmful to local } \\
\text { wildlife }\end{array}$ & $\square$ & $\square$ & $\square$ & $\square$ & $\square$ \\
\hline $\begin{array}{l}\text { i) causes parking and || } \\
\text { traffic problems }\end{array}$ & $\square$ & $\square$ & $\square$ & $\square$ & $\square$ \\
\hline $\begin{array}{l}\text { k) leads to the } \\
\text { creation of } \\
\text { recreational parks }\end{array}$ & $\square$ & $\square$ & $\square$ & $\square$ & $\square$ \\
\hline $\begin{array}{l}\text { l) Other (please } \\
\text { specify) }\end{array}$ & $\square$ & $\square$ & $\square$ & $\square$ & $\square$ \\
\hline
\end{tabular}


Q8. This question focuses on the economic impacts of freedom camping on Taupō District.

Please state your level of agreement with each of the following statements by ticking one of the boxes.

\begin{tabular}{|c|c|c|c|c|c|}
\hline $\begin{array}{l}\text { I think freedom } \\
\text { camping... }\end{array}$ & $\begin{array}{l}\text { Disagree } \\
\text { (1) }\end{array}$ & $\begin{array}{c}\text { Somewhat } \\
\text { Disagree } \\
(2) \\
\end{array}$ & $\begin{array}{c}\text { Neither Agree nor } \\
\text { Disagree } \\
\text { (3) }\end{array}$ & $\begin{array}{c}\text { Somewhat } \\
\text { Agree } \\
(4) \\
\end{array}$ & $\begin{array}{c}\text { Agree } \\
\text { (5) }\end{array}$ \\
\hline $\begin{array}{l}\text { a) improves my } \\
\text { personal income }\end{array}$ & $\square$ & $\square$ & $\square$ & $\square$ & $\square$ \\
\hline $\begin{array}{l}\text { b) leads to } \\
\text { employment } \\
\text { opportunities in the } \\
\text { community }\end{array}$ & $\square$ & $\square$ & $\square$ & $\square$ & $\square$ \\
\hline $\begin{array}{l}\text { c) is a drain on } \\
\text { community resources }\end{array}$ & $\square$ & $\square$ & $\square$ & $\square$ & $\square$ \\
\hline $\begin{array}{l}\text { d) increases the cost } \\
\text { of living }\end{array}$ & $\square$ & $\square$ & $\square$ & $\square$ & $\square$ \\
\hline $\begin{array}{l}\text { e) benefits local } \\
\text { businesses }\end{array}$ & $\square$ & $\square$ & $\square$ & $\square$ & $\square$ \\
\hline $\begin{array}{l}\text { f) attracts more } \\
\text { spending }\end{array}$ & $\square$ & $\square$ & $\square$ & $\square$ & $\square$ \\
\hline $\begin{array}{l}\text { g) is a form of } \\
\text { freeloading }\end{array}$ & $\square$ & $\square$ & $\square$ & $\square$ & $\square$ \\
\hline $\begin{array}{l}\text { h) Other (please } \\
\text { specify) }\end{array}$ & $\square$ & $\square$ & $\square$ & $\square$ & $\square$ \\
\hline
\end{tabular}


Section 3: This section focuses on your overall attitudes towards Freedom Camping in Taupō District.

Q9. Please state your level of agreement with each of the following statements by ticking one of the boxes.

\begin{tabular}{|c|c|c|c|c|c|}
\hline & $\begin{array}{c}\text { Disagree } \\
\text { (1) }\end{array}$ & $\begin{array}{c}\text { Somewhat } \\
\text { Disagree } \\
(2)\end{array}$ & $\begin{array}{c}\text { Neither Agree nor } \\
\text { Disagree } \\
\text { (3) }\end{array}$ & $\begin{array}{c}\text { Somewhat } \\
\text { Agree } \\
(4)\end{array}$ & $\begin{array}{c}\text { Agree } \\
(5)\end{array}$ \\
\hline $\begin{array}{l}\text { a) I think improving } \\
\text { freedom camping } \\
\text { facilities is a waste of } \\
\text { ratepayer money }\end{array}$ & $\square$ & $\square$ & $\square$ & $\square$ & $\square$ \\
\hline $\begin{array}{l}\text { b) I am against new } \\
\text { facilities that will } \\
\text { attract more freedom } \\
\text { campers }\end{array}$ & $\square$ & $\square$ & $\square$ & $\square$ & $\square$ \\
\hline $\begin{array}{l}\text { c) I think the overall } \\
\text { benefits of freedom } \\
\text { camping outweigh } \\
\text { the costs }\end{array}$ & $\square$ & $\square$ & $\square$ & $\square$ & $\square$ \\
\hline $\begin{array}{l}\text { d) I think local } \\
\text { government should } \\
\text { restrict freedom } \\
\text { camping more }\end{array}$ & $\square$ & $\square$ & $\square$ & $\square$ & $\square$ \\
\hline $\begin{array}{l}\text { e) Planning by the } \\
\text { government can } \\
\text { control the impact of } \\
\text { freedom camping on } \\
\text { the ecological } \\
\text { environment }\end{array}$ & $\square$ & $\square$ & $\square$ & $\square$ & $\square$ \\
\hline $\begin{array}{l}\text { f) I would support } \\
\text { local levies on } \\
\text { freedom camping }\end{array}$ & $\square$ & $\square$ & $\square$ & $\square$ & $\square$ \\
\hline $\begin{array}{l}\text { g) Freedom campers } \\
\text { should pay more } \\
\text { than locals to visit } \\
\text { parks and outdoor } \\
\text { recreation facilities }\end{array}$ & $\square$ & $\square$ & $\square$ & $\square$ & $\square$ \\
\hline $\begin{array}{l}\text { h) Freedom camping } \\
\text { is a right for New } \\
\text { Zealanders }\end{array}$ & $\square$ & $\square$ & $\square$ & $\square$ & $\square$ \\
\hline
\end{tabular}


Q10. Please select which statement you agree with the most.

\begin{tabular}{|c|c|c|c|c|c|}
\hline & $\begin{array}{l}\text { Worsened } \\
\text { (1) }\end{array}$ & $\begin{array}{l}\text { Somewhat } \\
\text { Worsened } \\
\text { (2) }\end{array}$ & $\begin{array}{c}\text { Not Made a } \\
\text { Difference } \\
\text { (3) }\end{array}$ & $\begin{array}{l}\text { Somewhat } \\
\text { Improved } \\
\text { (4) }\end{array}$ & $\begin{array}{c}\text { Improved } \\
\text { (5) }\end{array}$ \\
\hline $\begin{array}{l}\text { a) How has freedom } \\
\text { camping impacted } \\
\text { the destination } \\
\text { image of Taupō } \\
\text { District? }\end{array}$ & $\square$ & $\square$ & $\square$ & $\square$ & $\square$ \\
\hline
\end{tabular}

Q11. Please select which statement you agree with the most.

\begin{tabular}{l||c|c|c|c|c|} 
& $\begin{array}{c}\text { Should Decrease } \\
\text { (1) }\end{array}$ & $\begin{array}{c}\text { Should } \\
\text { Somewhat } \\
\text { Decrease } \\
\text { (2) }\end{array}$ & $\begin{array}{c}\text { Is Appropriate } \\
\text { (3) }\end{array}$ & $\begin{array}{c}\text { Should } \\
\text { Somewhat } \\
\text { Increase } \\
\text { (4) }\end{array}$ & $\begin{array}{c}\text { Should Increase } \\
\text { (5) }\end{array}$ \\
\hline $\begin{array}{l}\text { a) The number of } \\
\text { freedom campers } \\
\text { in Taupō District... }\end{array}$ & $\square$ & $\square$ & $\square$ & $\square$ & $\square$ \\
\hline $\begin{array}{l}\text { b) The number of } \\
\text { tourists in Taupō } \\
\text { District ... }\end{array}$ & $\square$ & $\square$ & $\square$ & $\square$ & $\square$ \\
\hline
\end{tabular}

Q12. Please provide your overall thoughts about freedom camping in New Zealand.

Section 4: This section contains questions about your demographics

Q13. Please indicate which age group you belong to.
18-24
25-34
व 35-44
口 45-54
55-64
$\square 65+$

Q14. Please indicate your gender.
$\square$ Male
$\square$ Female
$\square$ Gender Diverse

Q15. Please indicate which ethnic group you identify the most with. (tick only one)
$\square$ NZ European
口 NZ Māori
$\checkmark$ Pacific Islander
$\square$ Asian
$\checkmark$ Other Ethnicity (please specify)

Thank you very much. Your views will contribute to the understanding of freedom camping impacts. Please return questionnaire to the sealed box. 


\section{Perceived Impacts of Freedom Camping}

Thank you for your participation in this research.

If you would like to go in the draw to win 1 of $2 \$ 50$ supermarket gift cards please complete and return this form to the sealed box provided (please separate this sheet from your questionnaire).

Preferred Supermarket (please tick one):

$\square$ Countdown $\quad \square$ PAK'nSAVE

Name:

Email Address:

If you win, you will be contacted via the email address provided and asked to supply a postal address for the delivery of the $\$ 50 \mathrm{Gift}$ Card.

Additionally, if you would like to receive a summary of the findings from this survey questionnaire, please tick the following box:

$\square$ Yes, I would like to receive a summary of the findings. 


\section{APPENDIX C: Data Collection Locations}

\section{Planned Locations}

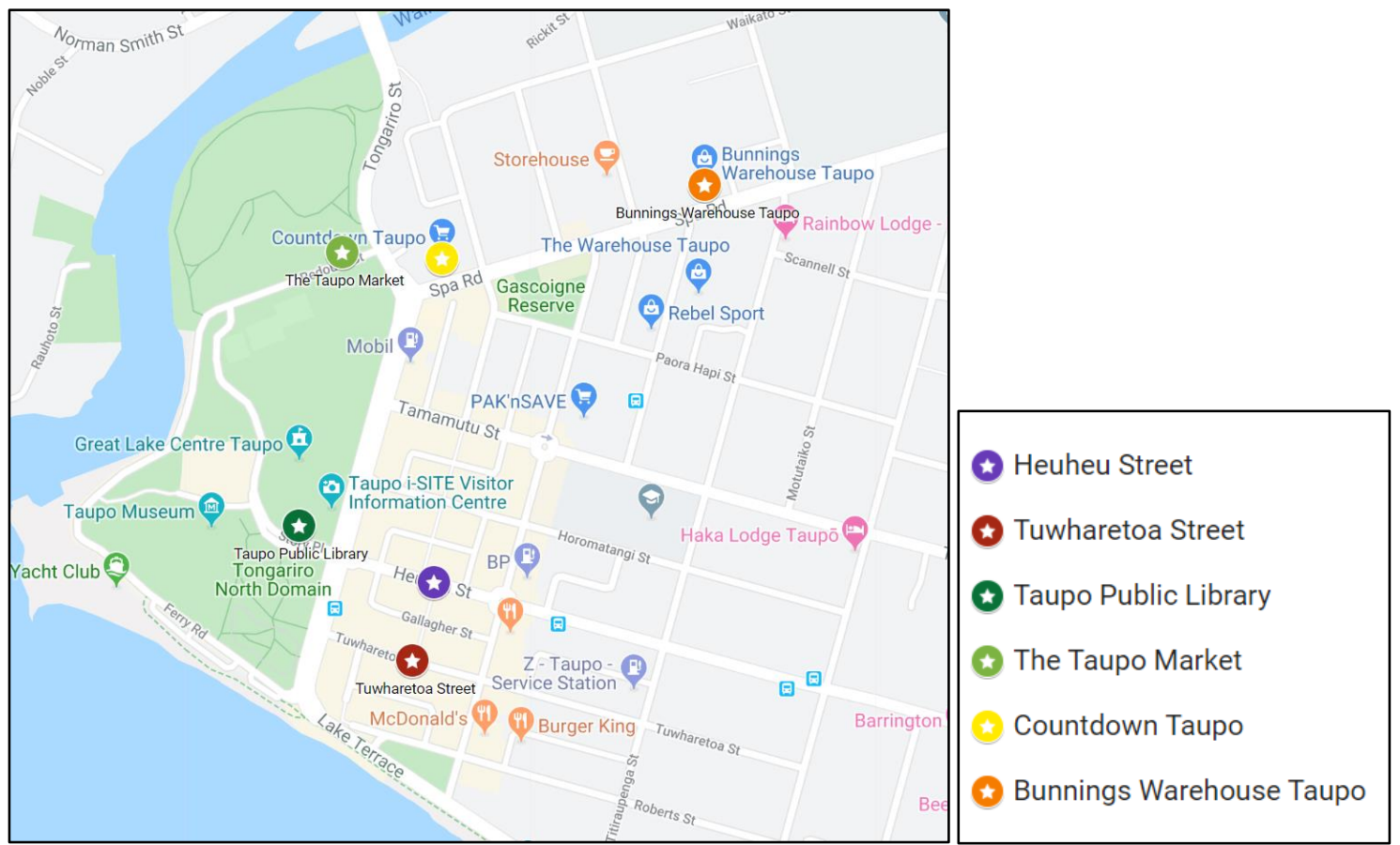

Google Maps (2020)

\section{Used Locations}

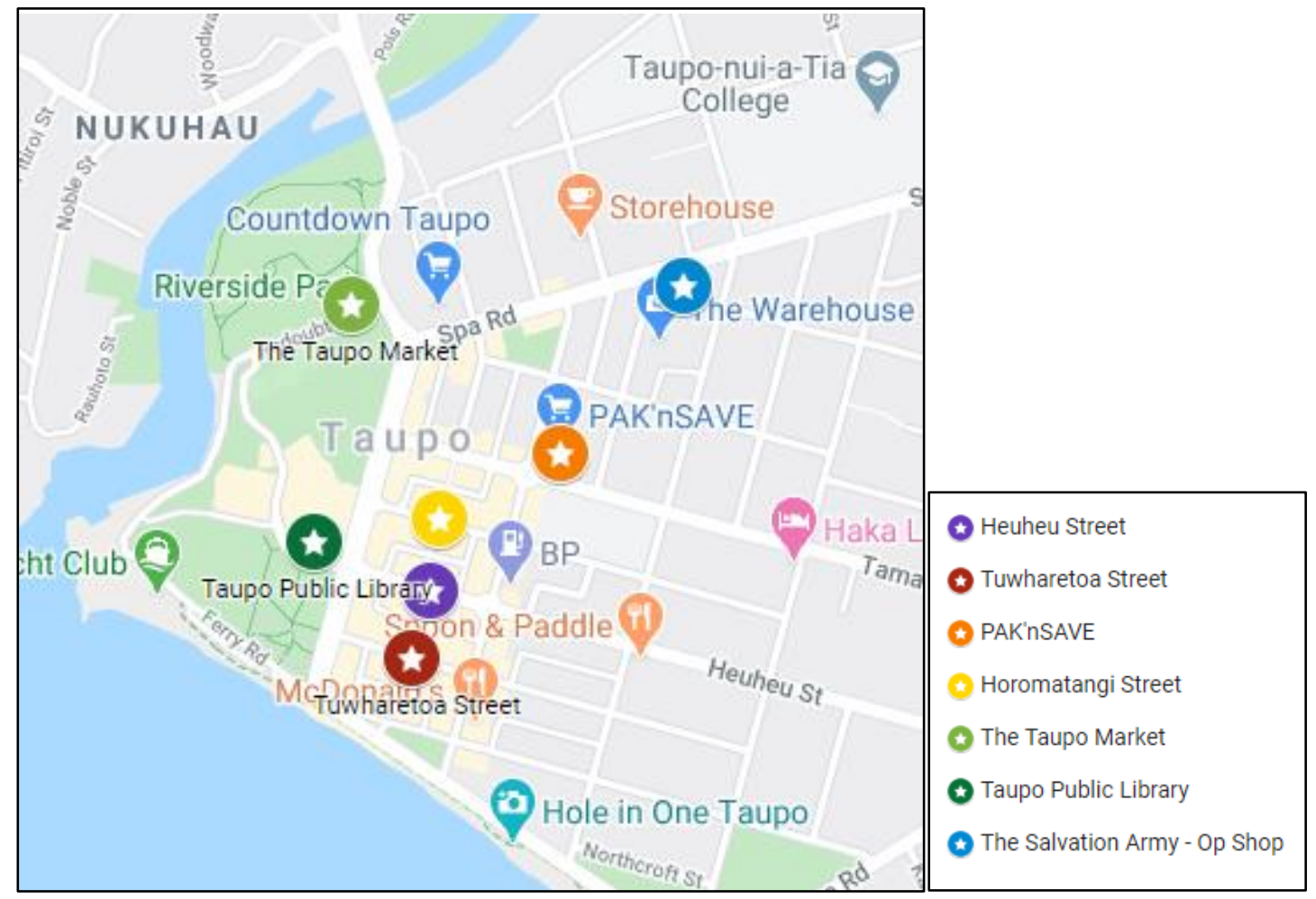

Google Maps (2020) 
The Salvation Army - Op Shop tr
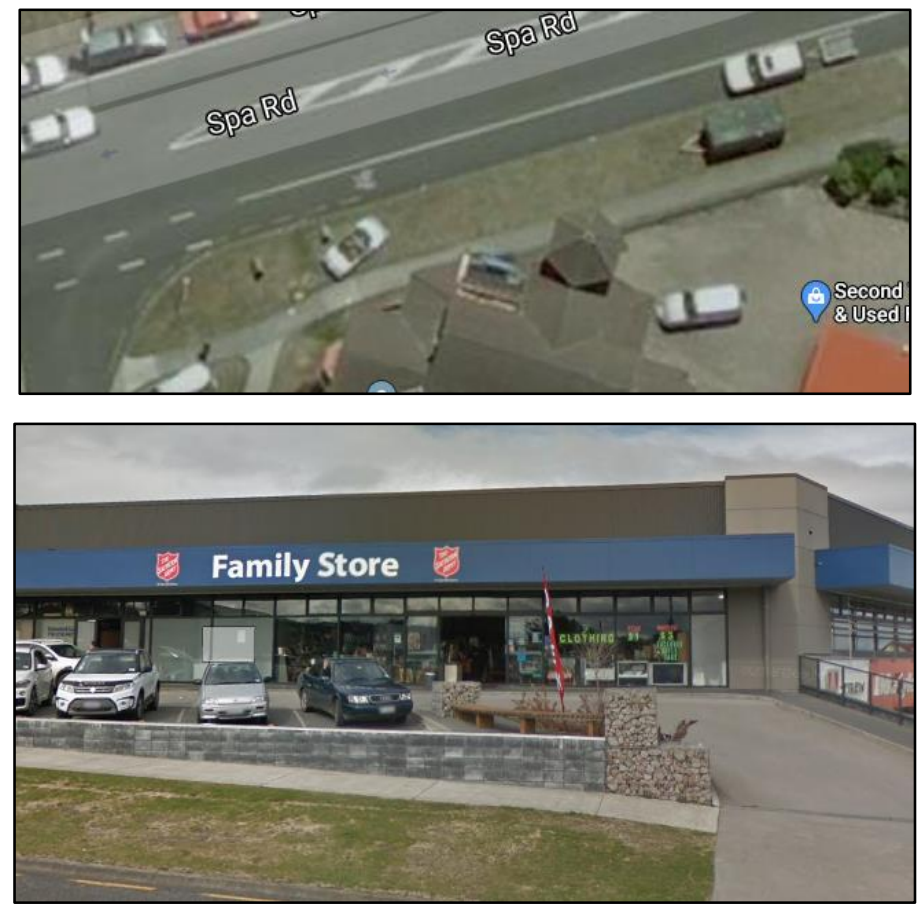

Google Maps (2020)

\section{Horomatangi Street}
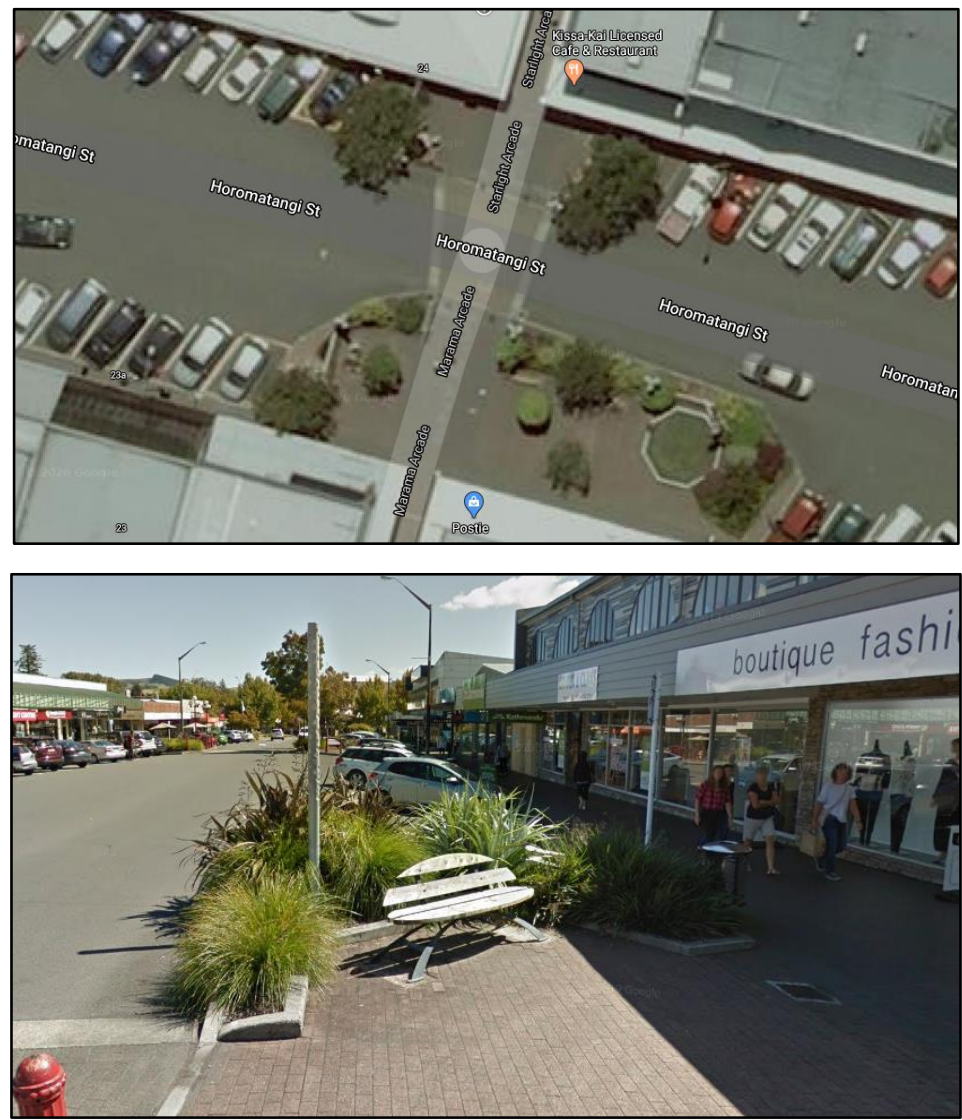

Google Maps (2020) 

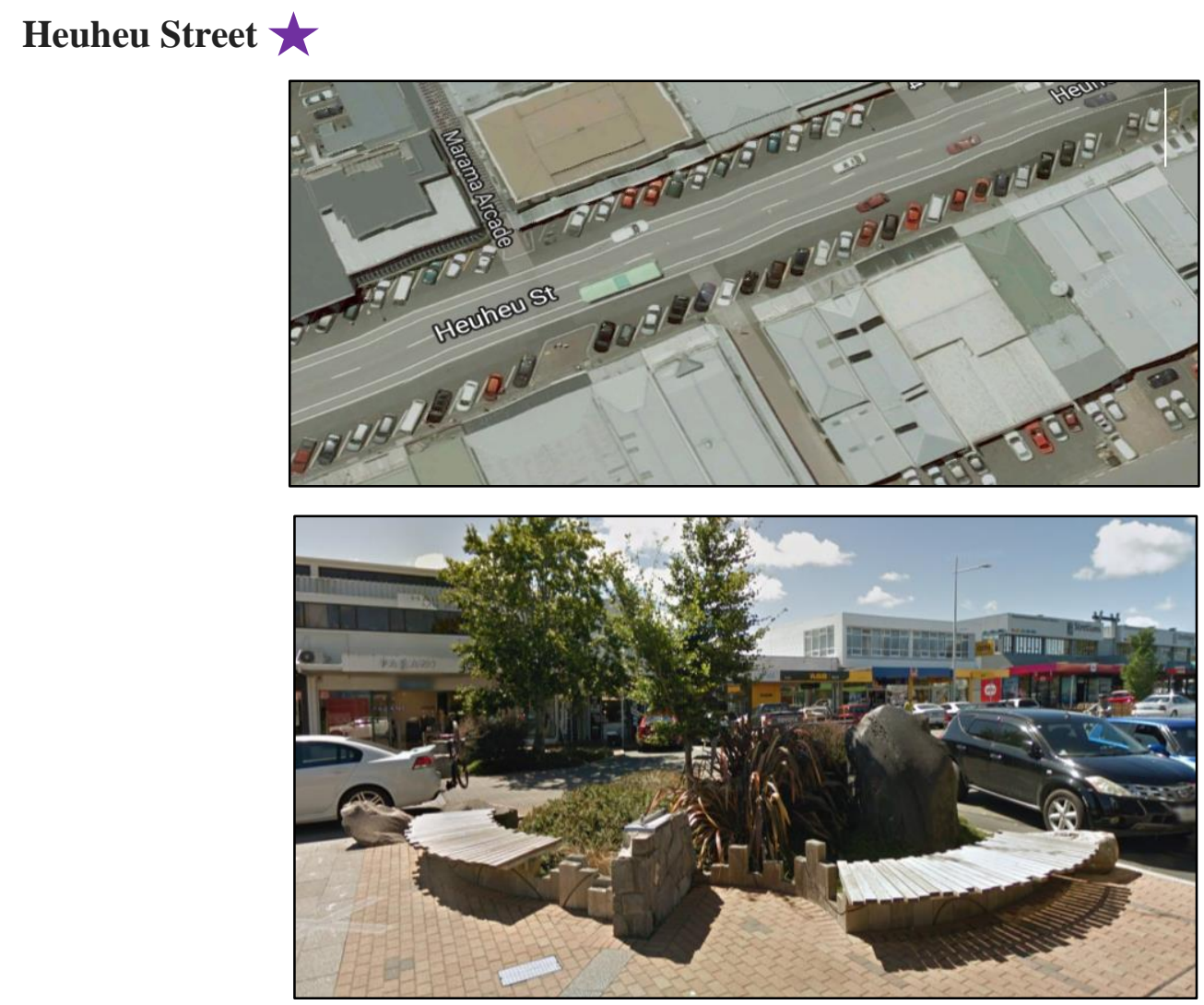

Google Maps (2020)

\section{Tuwharetoa Street 차}
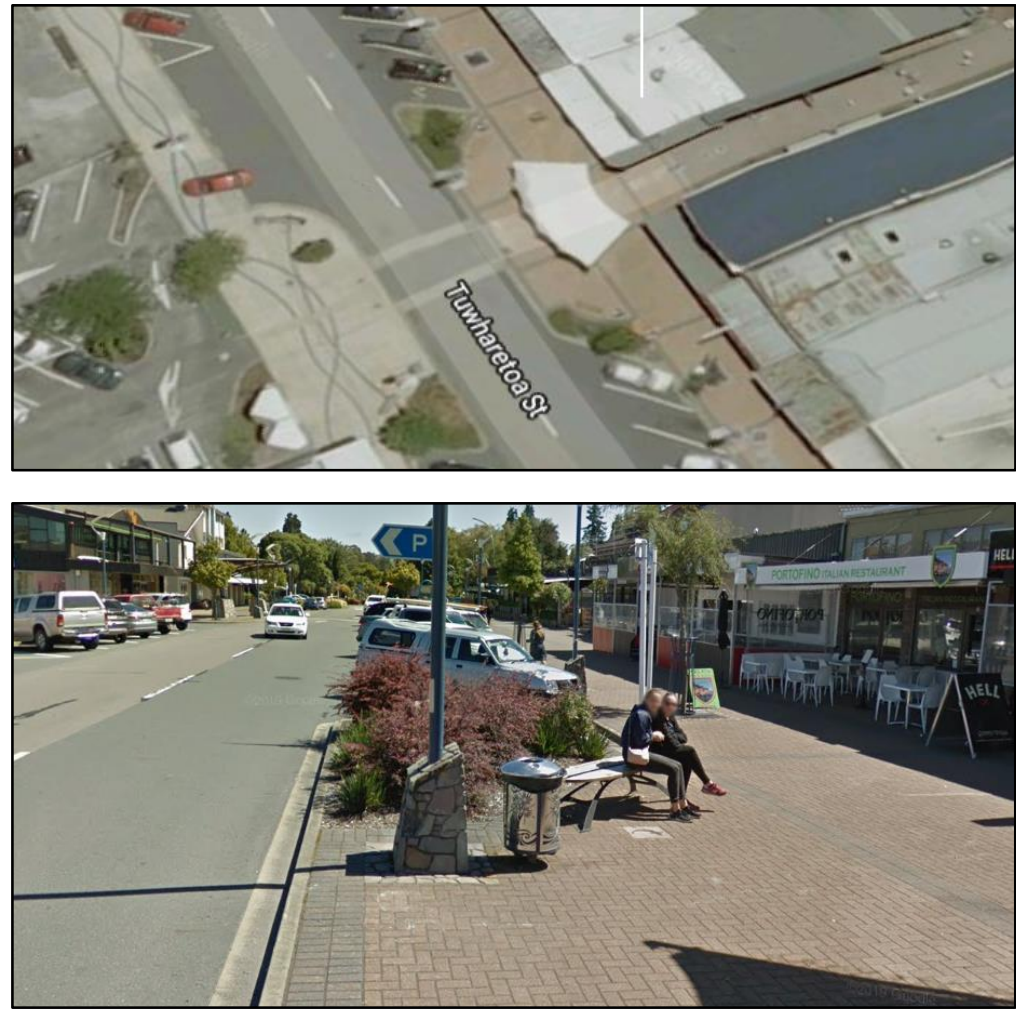

Google Maps (2020) 


\section{Taupō Public Library}
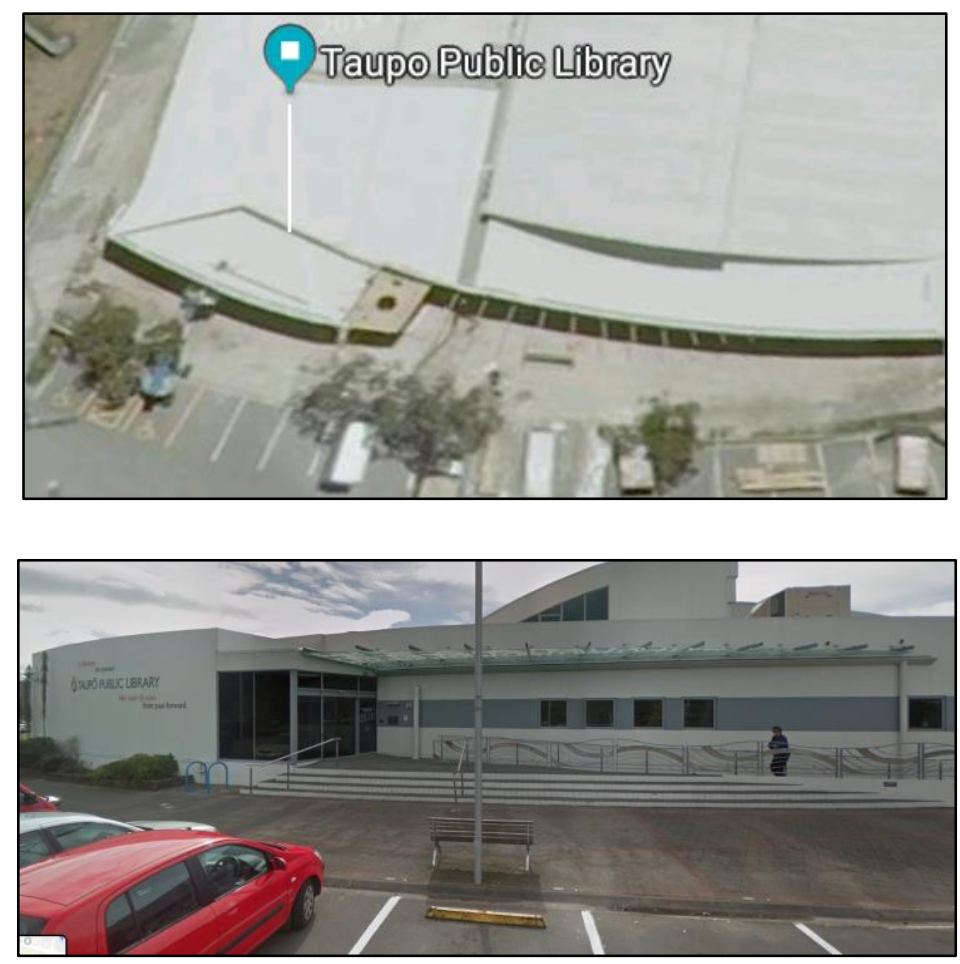

Google Maps (2020)

The Taupō Market
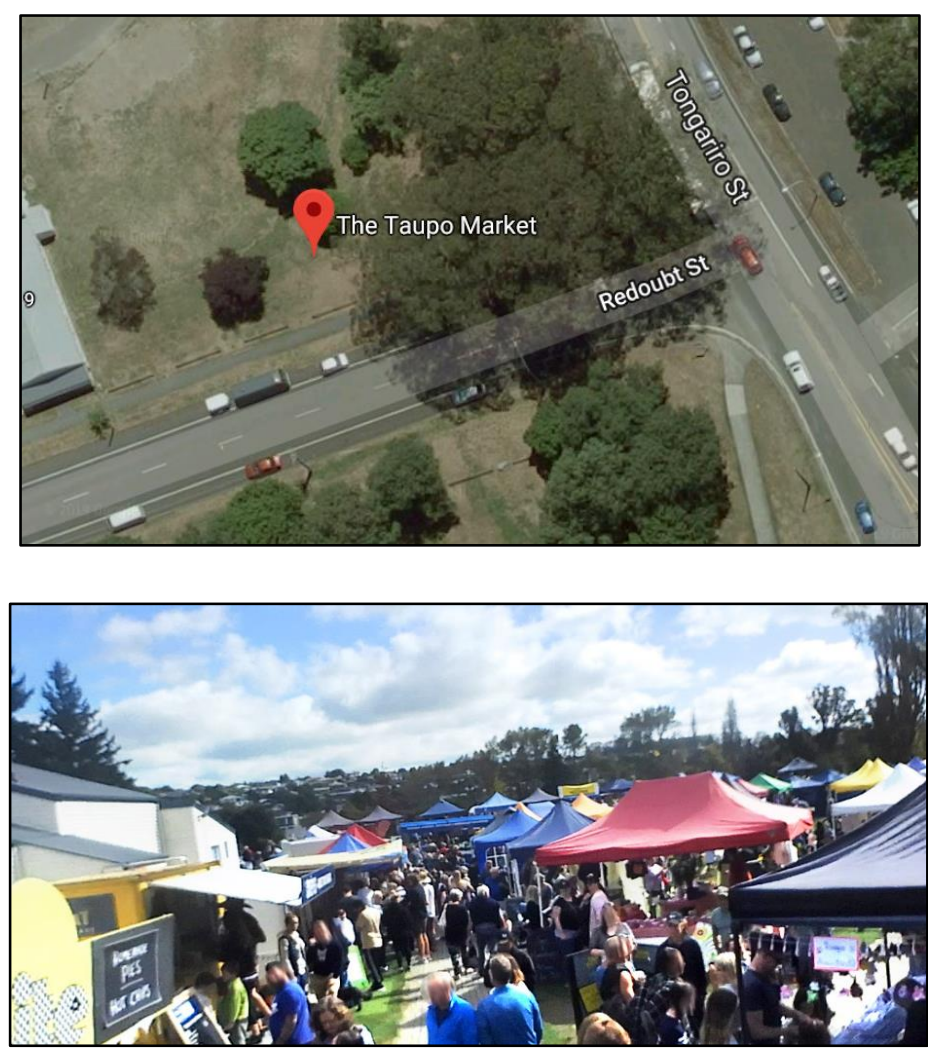

Google Maps (2020) 
PAK'nSAVE Taupō

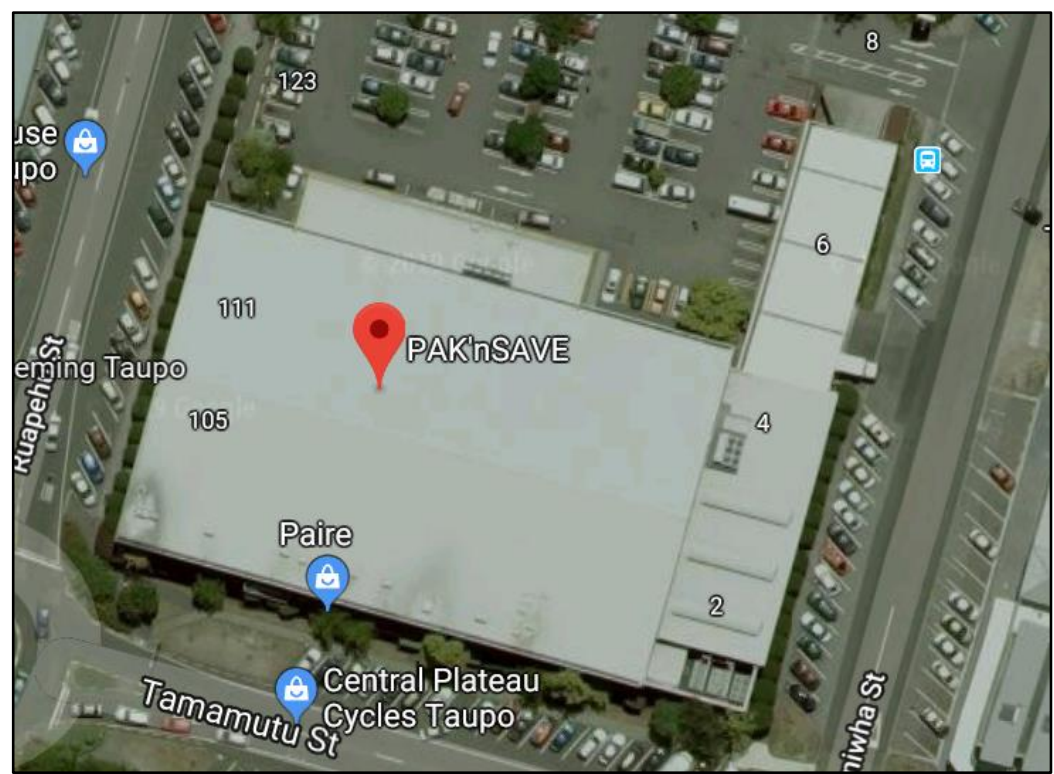

Google Maps (2020) 
APPENDIX D: Data Collection Timetable

\begin{tabular}{|c|c|c|c|c|c|c|c|c|}
\hline Time & $\begin{array}{l}\text { Morning } \\
10.00 \mathrm{am}\end{array}$ & $\begin{array}{l}\text { Morning } \\
11.00 \mathrm{am}\end{array}$ & $\begin{array}{l}\text { Lunch } \\
12.00 \mathrm{pm}\end{array}$ & Lunch 1.00pm & $\begin{array}{l}\text { Break } \\
2.00 \mathrm{pm}\end{array}$ & $\begin{array}{l}\text { After School } \\
3.00 \mathrm{pm}\end{array}$ & $\begin{array}{l}\text { After School } \\
4.00 \mathrm{pm}\end{array}$ & Evening $5.00 \mathrm{pm}$ \\
\hline $\begin{array}{l}\text { Friday } 22^{\text {nd }} \\
\text { November } \\
\text { (Pilot Survey) }\end{array}$ & $\begin{array}{l}\text { The Salvation } \\
\text { Army - Op } \\
\text { Shop }\end{array}$ & $\begin{array}{l}\text { The Salvation } \\
\text { Army - Op } \\
\text { Shop }\end{array}$ & $\begin{array}{l}\text { The Salvation } \\
\text { Army - Op } \\
\text { Shop }\end{array}$ & Edit Survey & Edit Survey & Edit Survey & Print Surveys & Print Surveys \\
\hline $\begin{array}{l}\text { Saturday } 23^{\text {rd }} \\
\text { November }\end{array}$ & Taupō Market & Taupō Market & Taupō Market & Public Library & Break & Public Library & Countdown & Break \\
\hline $\begin{array}{l}\text { Sunday } 24^{\text {th }} \\
\text { November }\end{array}$ & Break & PAK'nSAVE & PAK'nSAVE & PAK'nSAVE & Break & $\begin{array}{l}\text { Tuwharetoa } \\
\text { Street }\end{array}$ & $\begin{array}{l}\text { Tuwharetoa } \\
\text { Street }\end{array}$ & $\begin{array}{l}\text { Tuwharetoa } \\
\text { Street }\end{array}$ \\
\hline $\begin{array}{l}\text { Monday } 25^{\text {th }} \\
\text { November }\end{array}$ & PAK'nSAVE & PAK'nSAVE & Heuheu Street & Heuheu Street & Break & $\begin{array}{l}\text { Horomatangi } \\
\text { Street }\end{array}$ & $\begin{array}{l}\text { Horomatangi } \\
\text { Street }\end{array}$ & $\begin{array}{l}\text { Horomatangi } \\
\text { Street }\end{array}$ \\
\hline $\begin{array}{l}\text { Tuesday } 26^{\text {th }} \\
\text { November }\end{array}$ & Public Library & Public Library & Public Library & Public Library & Break & $\begin{array}{l}\text { The Salvation } \\
\text { Army - Op } \\
\text { Shop }\end{array}$ & $\begin{array}{l}\text { The Salvation } \\
\text { Army - Op } \\
\text { Shop }\end{array}$ & Break \\
\hline $\begin{array}{l}\text { Wednesday } 27^{\text {th }} \\
\text { November }\end{array}$ & $\begin{array}{l}\text { Tuwharetoa } \\
\text { Street }\end{array}$ & $\begin{array}{l}\text { Tuwharetoa } \\
\text { Street }\end{array}$ & $\begin{array}{l}\text { Tuwharetoa } \\
\text { Street }\end{array}$ & Break & Break & Break & Break & Break \\
\hline $\begin{array}{l}\text { Thursday } 28^{\text {th }} \\
\text { November }\end{array}$ & PAK'nSAVE & PAK'nSAVE & Heuheu Street & Heuheu Street & Break & $\begin{array}{l}\text { The Salvation } \\
\text { Army - Op } \\
\text { Shop }\end{array}$ & $\begin{array}{l}\text { The Salvation } \\
\text { Army - Op } \\
\text { Shop }\end{array}$ & Break \\
\hline $\begin{array}{l}\text { Friday } 29^{\text {th }} \\
\text { November }\end{array}$ & Public Library & Public Library & Public Library & Public Library & Break & $\begin{array}{l}\text { Horomatangi } \\
\text { Street }\end{array}$ & $\begin{array}{l}\text { Horomatangi } \\
\text { Street }\end{array}$ & $\begin{array}{l}\text { Horomatangi } \\
\text { Street }\end{array}$ \\
\hline $\begin{array}{l}\text { Saturday } 30^{\text {th }} \\
\text { November }\end{array}$ & Taupō Market & Taupō Market & Taupō Market & Break & Break & Break & Break & Break \\
\hline $\begin{array}{l}\text { Sunday } 1^{\text {st }} \\
\text { December }\end{array}$ & Break & $\begin{array}{l}\text { Local } \\
\text { Businesses }\end{array}$ & $\begin{array}{l}\text { Local } \\
\text { Businesses }\end{array}$ & $\begin{array}{l}\text { Local } \\
\text { Businesses }\end{array}$ & Break & $\begin{array}{l}\text { Local } \\
\text { Businesses }\end{array}$ & $\begin{array}{l}\text { Local } \\
\text { Businesses }\end{array}$ & Break \\
\hline
\end{tabular}


Data Collection Timetable Cont.

\begin{tabular}{|c|c|c|c|c|c|c|c|c|}
\hline Time & $\begin{array}{l}\text { Morning } \\
\text { 10.00am }\end{array}$ & $\begin{array}{l}\text { Morning } \\
11.00 \mathrm{am}\end{array}$ & $\begin{array}{l}\text { Lunch } \\
12.00 \mathrm{pm}\end{array}$ & Lunch 1.00pm & $\begin{array}{l}\text { Break } \\
2.00 \mathrm{pm}\end{array}$ & $\begin{array}{l}\text { After School } \\
3.00 \mathrm{pm}\end{array}$ & $\begin{array}{l}\text { After School } \\
4.00 \mathrm{pm}\end{array}$ & Evening $5.00 \mathrm{pm}$ \\
\hline $\begin{array}{l}\text { Monday } 2^{\text {nd }} \\
\text { December }\end{array}$ & Break & $\begin{array}{l}\text { Local } \\
\text { Businesses }\end{array}$ & $\begin{array}{l}\text { Local } \\
\text { Businesses }\end{array}$ & $\begin{array}{l}\text { Local } \\
\text { Businesses }\end{array}$ & Break & Public Library & Public Library & Public Library \\
\hline $\begin{array}{l}\text { Tuesday } 3^{\text {rd }} \\
\text { December }\end{array}$ & $\begin{array}{l}\text { The Salvation } \\
\text { Army - Op } \\
\text { Shop }\end{array}$ & $\begin{array}{l}\text { The Salvation } \\
\text { Army - Op } \\
\text { Shop }\end{array}$ & $\begin{array}{l}\text { The Salvation } \\
\text { Army - Op } \\
\text { Shop }\end{array}$ & $\begin{array}{l}\text { The Salvation } \\
\text { Army - Op } \\
\text { Shop }\end{array}$ & Break & $\begin{array}{l}\text { Horomatangi } \\
\text { Street }\end{array}$ & $\begin{array}{l}\text { Horomatangi } \\
\text { Street }\end{array}$ & Break \\
\hline $\begin{array}{l}\text { Wednesday } 4^{\text {th }} \\
\text { December }\end{array}$ & $\begin{array}{l}\text { Horomatangi } \\
\text { Street }\end{array}$ & $\begin{array}{l}\text { Horomatangi } \\
\text { Street }\end{array}$ & $\begin{array}{l}\text { Tuwharetoa } \\
\text { Street }\end{array}$ & $\begin{array}{l}\text { Tuwharetoa } \\
\text { Street }\end{array}$ & Break & $\begin{array}{l}\text { Local } \\
\text { Businesses }\end{array}$ & $\begin{array}{l}\text { Local } \\
\text { Businesses }\end{array}$ & $\begin{array}{l}\text { Local } \\
\text { Businesses }\end{array}$ \\
\hline $\begin{array}{l}\text { Thursday } 5^{\text {th }} \\
\text { December }\end{array}$ & $\begin{array}{l}\text { The Salvation } \\
\text { Army - Op } \\
\text { Shop }\end{array}$ & $\begin{array}{l}\text { The Salvation } \\
\text { Army - Op } \\
\text { Shop }\end{array}$ & Heuheu Street & Heuheu Street & Break & Public Library & Public Library & Public Library \\
\hline $\begin{array}{l}\text { Friday } 6^{\text {th }} \\
\text { December }\end{array}$ & $\begin{array}{l}\text { Local } \\
\text { Businesses }\end{array}$ & $\begin{array}{l}\text { Local } \\
\text { Businesses }\end{array}$ & $\begin{array}{l}\text { Local } \\
\text { Businesses }\end{array}$ & Break & Break & $\begin{array}{l}\text { The Salvation } \\
\text { Army - Op } \\
\text { Shop }\end{array}$ & $\begin{array}{l}\text { The Salvation } \\
\text { Army - Op } \\
\text { Shop }\end{array}$ & Break \\
\hline $\begin{array}{l}\text { Saturday } 7^{\text {th }} \\
\text { December }\end{array}$ & Taupō Market & Taupō Market & Taupō Market & Public Library & Break & Public Library & $\begin{array}{l}\text { Horomatangi } \\
\text { Street }\end{array}$ & $\begin{array}{l}\text { Horomatangi } \\
\text { Street }\end{array}$ \\
\hline $\begin{array}{l}\text { Sunday } 8^{\text {th }} \\
\text { December }\end{array}$ & Break & $\begin{array}{l}\text { Local } \\
\text { Businesses }\end{array}$ & $\begin{array}{l}\text { Local } \\
\text { Businesses }\end{array}$ & $\begin{array}{l}\text { Local } \\
\text { Businesses }\end{array}$ & Break & Break & Break & Break \\
\hline
\end{tabular}




\section{APPENDIX E: Research Results}

\section{E1 Environmental and Community Concerns}

\section{Boxplot with Outlier}

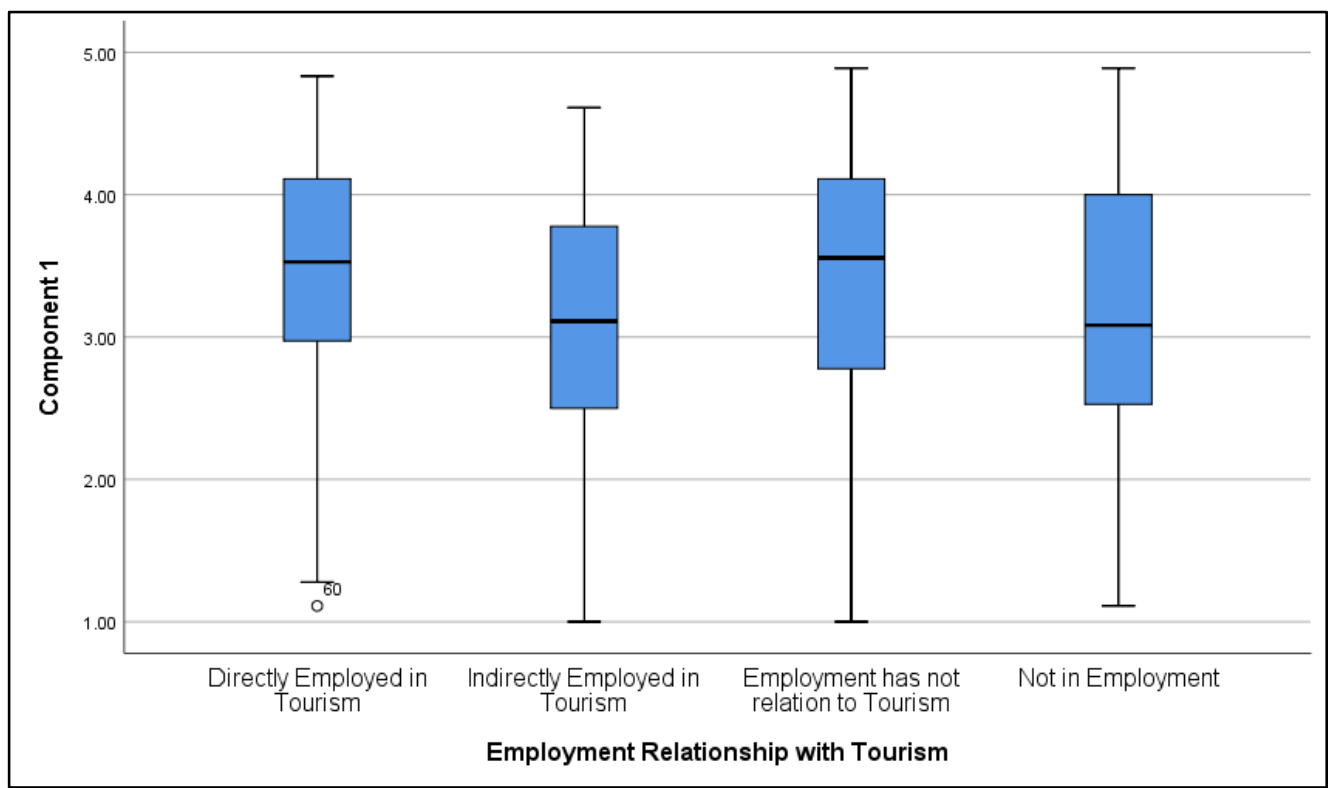

\section{Levene's Test}

\begin{tabular}{lc}
\hline \multicolumn{2}{c}{ Test of Homogeneity of Variances } \\
\hline & Sig. \\
Component 1 & .608 \\
\hline
\end{tabular}

Environmental and Community Concerns Score by Employment Relationship

\begin{tabular}{|c|c|c|c|c|c|c|c|c|}
\hline \multicolumn{9}{|c|}{ Descriptives } \\
\hline \multirow[b]{4}{*}{ Component 1} & \multirow[b]{4}{*}{$\mathrm{N}$} & \multirow[b]{4}{*}{ Mean } & \multicolumn{4}{|c|}{ 95\% Confidence } & \multirow[b]{4}{*}{ Minimum } & \multirow[b]{4}{*}{ Maximum } \\
\hline & & & & & Interval $\mathrm{f}$ & Mean & & \\
\hline & & & & Std. & Lower & Upper & & \\
\hline & & & SD & Error & Bound & Bound & & \\
\hline Directly Employed & 72 & 3.4614 & .83407 & .09830 & 3.2654 & 3.6574 & 1.11 & 4.83 \\
\hline Indirectly Employed & 33 & 3.1599 & .96082 & .16726 & 2.8192 & 3.5006 & 1.00 & 4.61 \\
\hline Employment No Relation & 45 & 3.3728 & .91407 & .13626 & 3.0982 & 3.6475 & 1.00 & 4.89 \\
\hline Not in Employment & 32 & 3.1962 & .99150 & .17527 & 2.8387 & 3.5537 & 1.11 & 4.89 \\
\hline Total & 182 & 3.3382 & .90735 & .06726 & 3.2055 & 3.4709 & 1.00 & 4.89 \\
\hline
\end{tabular}




\section{Mean Bar Chart}

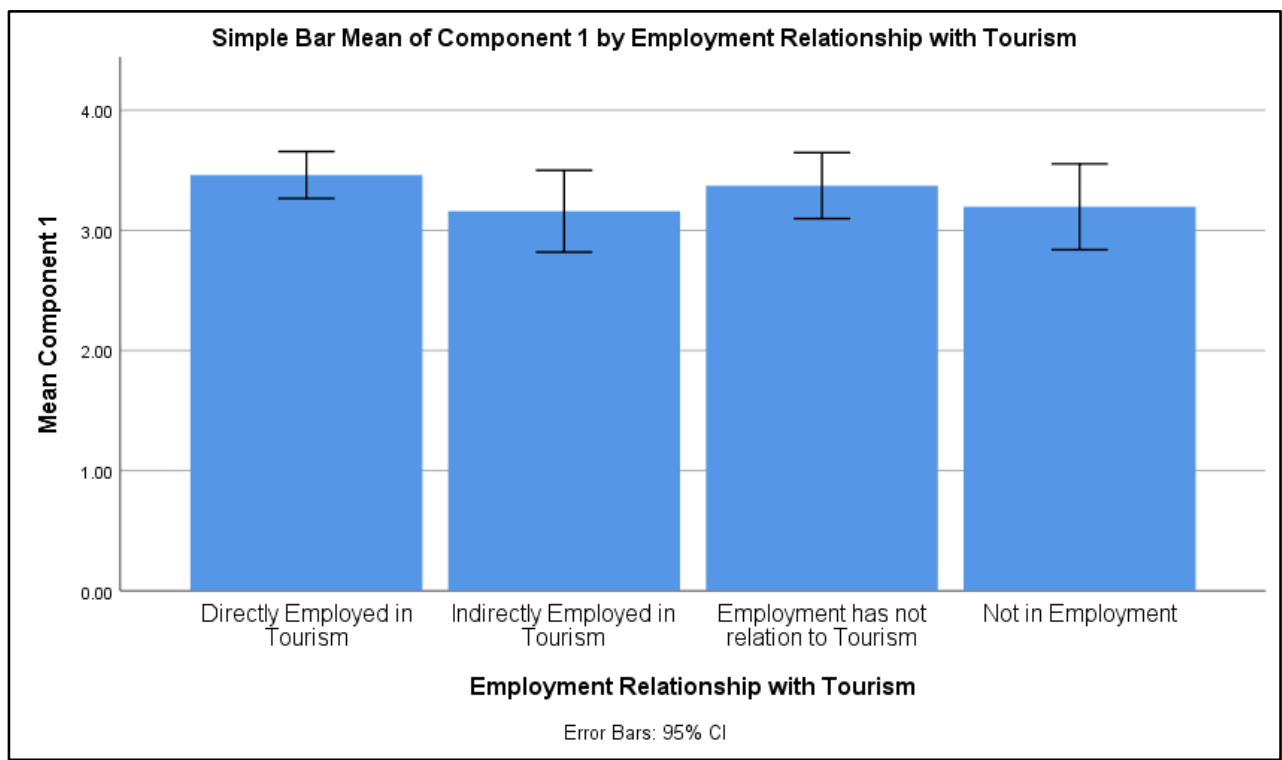

One-way ANOVA (Environmental and Community Concerns - Employment Relationship)

\begin{tabular}{llrrrrr}
\hline \multicolumn{9}{c}{ ANOVA } & & & & \\
\hline & \multicolumn{2}{c}{ Sum of Squares } & df & Mean Square & F & Sig. \\
\hline Component 11 & Between Groups & 2.841 & 3 & .947 & 1.153 & .329 \\
& Within Groups & 146.173 & 178 & .821 & & \\
& Total & 149.014 & 181 & & & \\
\hline
\end{tabular}




\section{E2 Personal and Community Benefits}

\section{Boxplot with Outlier}

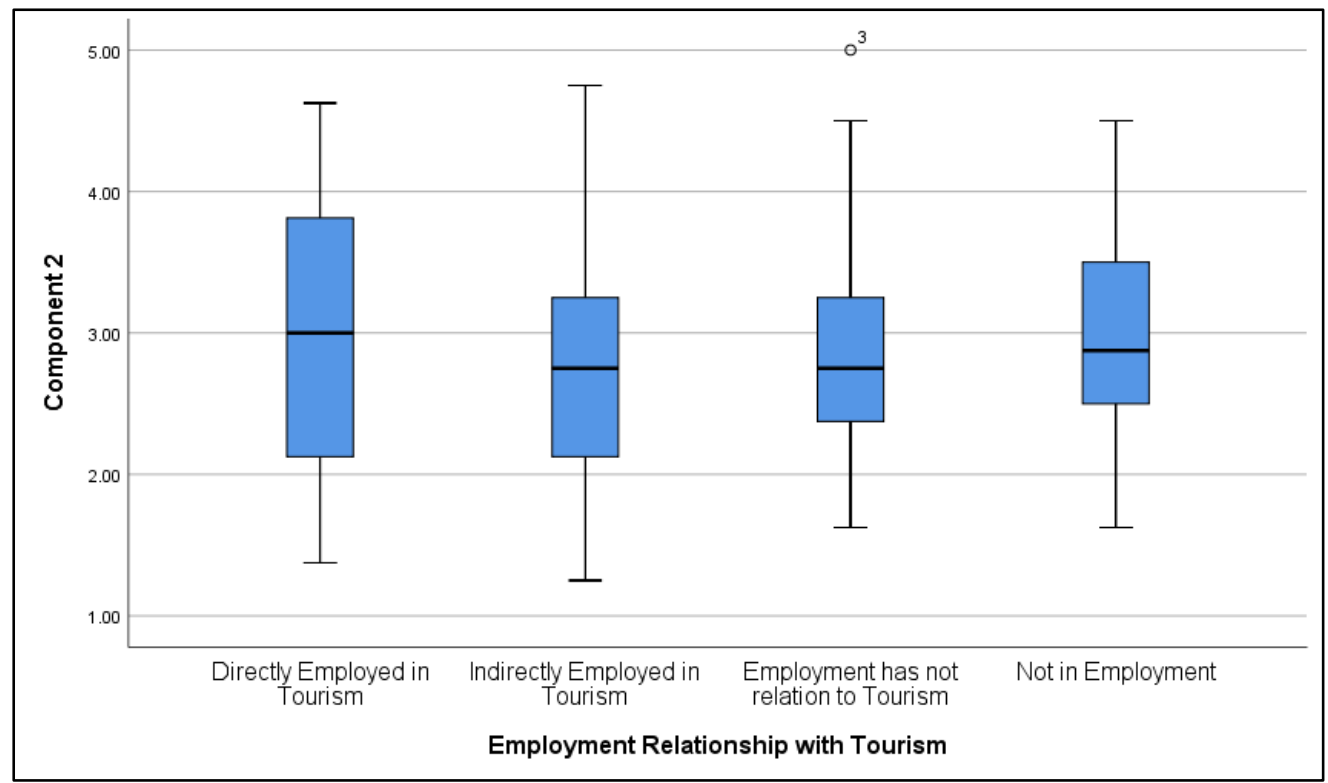

\section{Levene's Test}

\begin{tabular}{lc}
\hline \multicolumn{2}{c}{ Test of Homogeneity of Variances } \\
\hline & Sig. \\
Component 2 & .059 \\
\hline
\end{tabular}

Personal and Community Benefits Score by Employment Relationship

\begin{tabular}{|c|c|c|c|c|c|c|c|c|}
\hline \multicolumn{9}{|c|}{ Descriptives } \\
\hline \multirow{3}{*}{ Component 2} & \multirow{3}{*}{$\mathrm{N}$} & \multirow{3}{*}{ Mean } & \multicolumn{6}{|c|}{$95 \%$ Confidence } \\
\hline & & & \multicolumn{6}{|c|}{ Interval for Mean } \\
\hline & & & $\begin{array}{c}\text { Std. } \\
\text { Deviation }\end{array}$ & $\begin{array}{l}\text { Std. } \\
\text { Error }\end{array}$ & Lower & Upper & רו & Maximum \\
\hline Directly Employed & 72 & 2.9948 & .92535 & .10905 & 2.7773 & 3.2122 & 1.38 & 4.63 \\
\hline Indirectly Employed & 33 & 2.7917 & .96048 & .16720 & 2.4511 & 3.1322 & 1.25 & 4.75 \\
\hline Employment No Relation & 45 & 2.8750 & .72300 & .10778 & 2.6578 & 3.0922 & 1.63 & 5.00 \\
\hline Not in Employment & 32 & 2.9648 & .79644 & .14079 & 2.6777 & 3.2520 & 1.63 & 4.50 \\
\hline Total & 182 & 2.9231 & .86068 & .06380 & 2.7972 & 3.0490 & 1.25 & 5.00 \\
\hline
\end{tabular}




\section{Mean Bar Chart}

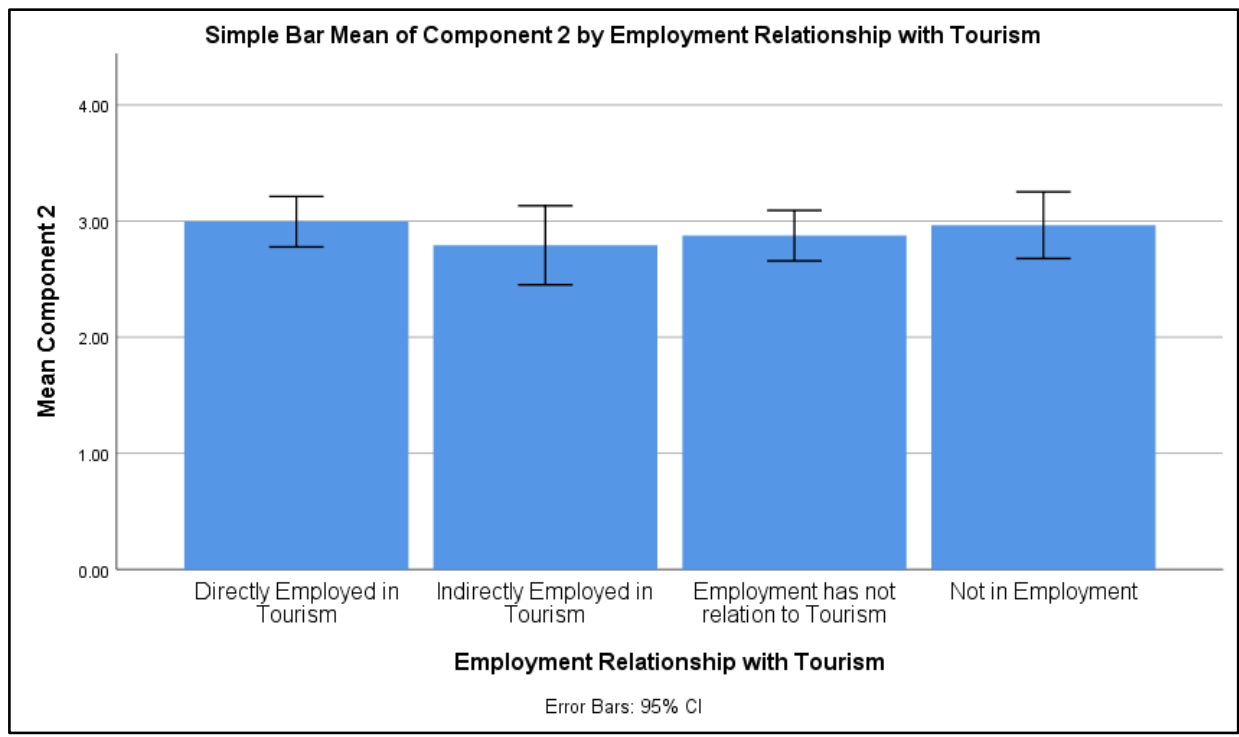

One-way ANOVA (Personal and Community Benefits - Employment Relationship)

\begin{tabular}{llrrrrr}
\hline \multicolumn{9}{c}{ ANOVA } & & & & \\
\hline & Sum of Squares & df & Mean Square & F & Sig. \\
\hline Component 2 & Between Groups & 1.100 & 3 & .367 & .491 & .689 \\
& Within Groups & 132.979 & 178 & .747 & & \\
& Total & 134.079 & 181 & & & \\
\hline
\end{tabular}

